\title{
Corporate and Product Identity in the Postnational Economy: Rethinking U.S. Trade Laws
}

\author{
Lan Cao†
}

\section{TABLE OF CONTENTS}

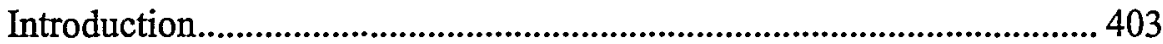

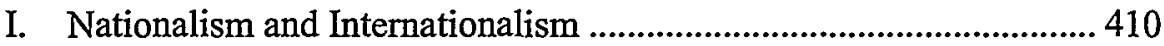

II. The Internationalization of the Market.......................................... 427

A. Globalization of Production................................................... 427

B. The Distributional Impact: Rich and Poor, High-Volume, High-Value

C. Confusion: Dilemmas Underlying Current Trade Law and

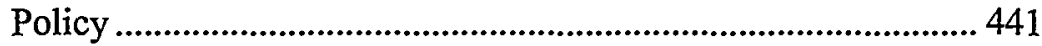

III. Towards a New Meaning of Nationality in the Global Economy .... 450

A. Reforming Corporate Nationality: A Proposed Domestic

Participation Test

1. Step One: Substantial Socioeconomic Participation ............ 454

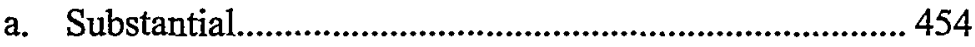

b. Socioeconomic Participation ....................................... 458

2. Step Two: The Participation Offset Right........................... 461

B. Reforming Product Nationality: A New Rule of Origin

Framework.

Copyright $\odot 2002$ California Law Review, Inc. California Law Review, Inc. (CLR) is a California nonprofit corporation. CLR and the authors are solely responsible for the content of their publications.

$\dagger$ Professor of Law, College of William and Mary School of Law. I thank Professors Richard Thompson Ford, Katherine M. Franke, Claire R. Kelly, John Lee, John O. McGinnis, Peter J. Spiro, and ChantaI Thomas for their comments. Special thanks go to Anya Sobodinska (J.D., Brooklyn Law School, 2000) for her outstanding research, suggestions, and helpful conversations throughout the period the Article was written. Thanks also to participants at the following faculty workshops and conferences where earlier drafts of the Article were presented: DePaul Law School Faculty Workshop; the Jurisprudence of Identity Workshop at the Center for the Study of Law and Culture, Columbia Law School; Workshop on New Scholarship in International Public and Private Law, European Law Research Center, Harvard Law School; Fordham Law School Faculty Workshop; the University of Connecticut Law School Faculty Workshop; and the William and Mary Law School Faculty Worhshop. Research assistance for the article was also provided by Emily Anderson, Colin Thakkar, and Ross Fulton (J.D. Candidates, William and Mary School of Law, 2003). I began this Article when I was on the faculty of Brooklyn Law School and would like to thank the Brooklyn Law School faculty and Dean Joan Wexler for a generous summer research stipend. 


\title{
Corporate and Product Identity in the Postnational Economy: Rethinking U.S. Trade Laws
}

\author{
Lan Cao
}

In the global economy, a General Motors automobile may involve South Korean assembly; Japanese engines; German design and style engineering; Taiwanese, Singaporean, and Japanese small components; British advertising and marketing; and Irish and Barbadian data processing. What is the country of origin of this product? How should U.S. trade laws evaluate a product's origin, if it is a global composite with research, assembly, processing, and manufacturing performed in different countries? Similarly, corporations have become increasingly global in orientation and operations. Even "national" corporations have lost their territorial ties to the state of their nationality. Through a phenomenon termed "global outsourcing" and foreign direct investment, and as a result of the transformation of the economy from an industrial to a postindustrial one, corporations are engaging in global webs of cross ownership and strategic alliances outside their home territories.

The trade laws of the U.S. are replete with references to "domestic industry," "domestic" corporations, and "domestic" products. U.S. trade laws, like those of other countries in the world trading system, remain rooted in antiquated understandings of "nationality" and "national origin." Without a thorough reassessment of these two concepts, the U.S. responds to the challenges posed by globalization in a piecemeal manner, its trade laws vacillating between the pull of nationalism and internationalism. The Article proposes an alternative that balances the current global reality with the nationalist call for a return to the local. To the extent that a "national" market can still be accurately identified, its identification does not come from the traditional conceptions of a national corporation or a national product, but from the one factor in the production process that is still territorial rather than globally oriented: the national workforce. Any company that meets what is termed a substantial socioeconomic participation test should be granted the benefits of nationality available under U.S. trade laws. 
A product's "national origin" should also be reassessed. Despite calls from nationalists to fortify national boundaries to protect domestic products and industry, products that are globally sourced are in fact the products of no one country in particular. Country-of-origin designations thus merely perpetuate this chimera of nationality in a world of internationality. The Article proposes to revise the interpretation of current rules to accomplish two objectives: first, to reflect the emergence of the postindustrial economy, and second, to address the nationalist fault lines required to ensure the continued political survival of the current trading system.

\section{INTRODUCTION}

In recent years, it has become increasingly difficult to determine the national origin of a product or the nationality of a corporation. Products appear to be made everywhere and also nowhere in particular, as shown on the following computer circuit label: "Made in one or more of the following countries: Korea, Hong Kong, Malaysia, Singapore, Taiwan, Mauritius, Thailand, Indonesia, Mexico, Philippines. The exact country of origin is unknown."

Similarly, corporations with a global presence have become increasingly denationalized, that is, unbounded by the territorial borders of their state of nationality. Even corporations that have been identified with a particular country may no longer be as "nationally" identified. "Americans may know that Jaguar cars are now American. But do they know that Burger King or Winchell's Donuts are British?"2 Indeed, global corporations now wish to present themselves not as nationals of a state but rather, as cosmopolitans of the world. A former executive of IBM was quoted as saying, "[f]or business purposes the boundaries that separate one nation from another are no more real than the equator. They are merely convenient denarcations of ethnic, linguistic and cultural entities.... Once management accepts this world economy, its view of the marketplace-and its planning-necessarily expand ...."3 Cross-border alliances and production have blurred the national identity of enterprises and products.

Without a thorough understanding of these developments, many countries, the United States mcluded, still maintain trade policies that are often disjomted and contradictory. For example, in 1991, the U.S. Customs Services refused to designate as "North American" Hondas built in Ohio

1. Benjanin R. Barber, Jihad vs. MCWorLd 14 (1995).

2. Michael Mann, Nation-States in Europe and Other Continents: Diversifying, Developing, Not Dying, DaEdalus, Summer 1993, at 115, 132. Winchell's Donut House is currently owned by Shato Holdings, a British Columbia company.

3. Quoted in Tom Nairn, Internationalism and the Second Coming, DaEdalus, Summer 1993, at $155,157$. 
and Ontario, charging that the Hondas at issue had less than $50 \%$ local content (a requirement of the Canada-U.S. Free Trade Agreement) and hence would not qualify for duty-free treatment when shipped from Honda's plant in Canada to the United States. The fact that Honda's operations in the United States at the time included a $\$ 2.2$ billion central Ohio complex that supported a payroll of $\$ 7.3$ million for 10,000 workers ${ }^{4}$ was not significant to the Customs determination. ${ }^{5}$

While U.S. Customs was charging that Honda Civics built in Marysville, Ohio, were not sufficiently North American, the United States was trying to convince the Europeans that Honda Accords also made in Marysville, Ohio, and shipped to the European market were all-American. The Bush Administration argued that the U.S.-assembled Hondas could not be included in the European Community and French quotas on Japanese imports because "the nameplate doesn't matter. This is an American car."

The United States, like other countries, is ill-equipped to address a fundamental issue that underlies trade laws today-how to think about nationality in a postnational and increasingly internationally integrated world. ${ }^{7}$ Despite the globalization of economics, the assumption underlying the trade laws of most countries is that the competitiveness of their national economy is essentially tied to the competitiveness of their "national" companies $^{8}$ as a matter of course. Yet, as a General Motors executive remarked, "[w] hat's nationality got to do with it anyway?" Globalization has transformed the very meaning of "nationality" and called into question the

4. Paul Magnusson et al., Honda: Is It an American Car?, Bus. WK., Nov. 18, 1991, at 105.

5. As a result, Honda was faced with $\$ 20$ million in back tariffs. And Canada, wishing to protect the Canadian jobs provided by Honda's Alliston, Ontario plant, had prominent Canadians lined up to defend Honda as North American and denounce U.S. action as "economic arson," Frédéric P. Cantin \& Andreas F. Lowenfeld, Rules of Origin, The Canada-U.S. FTA, and the Honda Case, 87 AM. J. INT'L L. 375, 383 n.37 (1993) (statement of Paul Martin, a Liberal Member of Parliament and the son of the Minister for External Affairs in the government of Prime Minister Pearson), and "terrorism," Magnusson, supra note 4, at 105 (statement of the former president of the Canadian Automotive Parts Manufacturers' Association), and U.S. officials as "real thugs." Id. (statement of the former president of the Canadian Automotive Parts Manufacturers' Association).

6. Magnusson, supra note 4, at 106 (quoting U.S. Trade Representative Carla A. Hills).

7. See, e.g., Peter D. Ehrenhaft, Book Review, 86 AM. J. INT'L L. 230, 231-32 (1992) (describing "a central notion of GATT: that all merchandise has a single nationality").

8. See, e.g., Laura D'Andrea Tyson, They Are Not Us: Why American Ownership Still Matters, AM. ProspeCt, Winter 1991, at 37 ("The tradition of identifying nations and corporations extends far back into the past when corporations served the monarchs who gave them special charters."); Robert B. Reich, Who Is Us?, HARv. Bus. Rev., Jan.-Feb. 1990, at 53.

9. Jenny King, Auto Industry Reaches the Point of Domestic BMWs and Toyotas and Imported Chryslers, CHI. TRIB., Feb. 17, 1999, at 4. Consumer preferences, langnages, geography, temperature, and safety standards might be influenced by nationality and thus might be relevant in a company's business or marketing decision making. But the nationality of a corporation no longer has much to do with where its products will be made. 
relationship between the state and the market, as states appear to relinquish their power to a market that increasingly transcends national boundaries. ${ }^{10}$

Indeed, the two gravitational centers of power in the international order today, the state and the market, have spawned a complex configuration of ancillary and dualistic rivalries: nationalism versus internationalism, political versus economic, sovereignty and self-sufficiency versus integration and interdependence. ${ }^{11}$ For some, the state is thought to be the sole or primary institutional entity that is capable of defending the political ideals of nationalism and sovereignty against economic globalization, where corporate production is easily globalized and manufacturing facilities are closed in one national jurisdiction and opened in the next. For others, the state's continued insistence on archaic categories, such as nationalism and territorial frontiers, merely stands in the way of open borders, of greater trade liberalization and greater harmonization of national laws deemed necessary for the removal of trade barriers. These recurrent disciplinary rivalries between the state and the market-the politics of identity versus the economics of profit ${ }^{12}$-are all the nore pronounced now because of the increasing globalization of production and the increasing mobility of goods, services, and capital across, and without regard for, national borders.

There are different responses to the apparent conflict between market and state. Generally speaking, nationalists defend the state as the site for politics, governance, and national cultures, and argue for a national trade policy that defends the national ntarket, national corporations, and national products from the international by fortifying national borders. ${ }^{13}$ This has generally meant favoring protectionism against "foreign" companies and "foreign" goods in favor of "domestic" ones. Nationalists advocate national, at times even localized, particularistic identities, as championed by the state $^{14}$ against cosmopolitan rootlessness, market expansions, and

10. New York Times columnist Thomas Friedman observed that globalization has eroded "the traditional boundaries between politics, culture, technology, finance, national security and ecology." Thomas L. Friedman, The Lexus and the Ol.1ve Tree 15 (1999). Given the imperatives of the global economy and "the difficulty of government regulation of international economic behavior... there is today hardly any subject that can be said to be effectively controlled by a single national sovereign." John H. Jackson, Reflections on International Economic Law, 17 U. PA. J. INT'L ECoN. L. 17, 24-25 (1996).

11. See generally Naim, supra note 3, at $\mathbf{1 5 9}$ ("Since the fall of Napoleon's empire, these two world views have existed in a permauent, uneasy tension with one another, the Siamese twin brothers of a single world-historical process.").

12. See BARBER, supra note 1 , at 7 .

13. For a discussion of the nationalist response, see infra Part 1 .

14. Since the Peace of Westphalia, the state has been the site of personal identity. Yet, in recent years, for many people, identity and loyalty are clustered around other nonstate forms, such as ethnicity, religion, or tribe. Take, for example, Rwanda, the former Yugoslavia, Slovakia, Quebec, and Indonesia, to name a few. See generally BARBER, supra note 1; see also infra note 30. 
global economic institutions such as the World Trade Organization ("WTO").

Internationalists, on the other hand, do not condemn globalization on a wholesale scale, but rather defend internationalization and the international order in various ways and at various levels. ${ }^{15}$ The internationalist relationship with nationalism has ranged from suspicion and mistrust of nationalist passion to attempts at managing and channeling nationalism in ways that are acceptable to the internationalist sensibility. On the whole, aside from the occasional call for a tighter regulatory framework, internationalists, especially in the economic field, are more or less comfortable with an international economic system that transcends the national or the cultural in order to insulate economic rationality against the interference of the state.

There are still other antiglobalization responses, both from the left and the right, that are neither strictly nationalist nor internationalist but a populist mix of the two. ${ }^{16}$ Witness the rise of grassroots movements that demand a return to more meaningful forms of democratic participation and local control- "the democratic taste for the neighborhood," 17 so to speak; or the proliferation of religious, environmental, organized labor, student, and other ad hoc groups, all opposed to economic globalization and the antinational, antisovereign, and antidemocratic tendencies perceived in international institutions such as the WTO. ${ }^{18}$

Yet, current responses, whether nationalist, internationalist or a mix thereof, have been inadequate for two separate but interrelated reasons. First, they do not pay sufficient attention to the impact globalization has had on the way corporations conduct themselves-that is, globally and not just nationally, resulting in an increasing disassociation between the corporation's activities and its state of nationality. Similarly, products are no longer produced in one or even two countries but are often composites of parts, each designed, assembled, processed, or manufactured in different national jurisdictions. These developments have eroded, as a practical

15. For a discussion of the intemationalist response, see infra Part I.

16. A much more blunt characterization of the antiglobalists was offered in Jim Chen, Globalization and Its Losers, 9 MinN. J. Global Trade 157 (2000).

17. Benjamin R. Barber, Constitutional Faith, in For Love of Country 34-35 (Joshua Cohen ed., 1996). Communitarians, for example, bemoan the emptiness of liberal cosmopolitanism and urge a return to a society marked less by "the politics of difference," Richard Rorty, The Unpatriotic Academy, BAltimore Sun, Feb. 17, 1994, at 19A, and more by "the emotion of national pride," id., and "the idea of a national identity," $i d$., joined by "habits of the heart." Amitai Etzioni, The SPIRIT of Community: Rights, Responsibilities, AND the CommunitaRian Agenda 24 (1993).

18. Globalization vs. Nature, N.Y. TIMEs, Nov. 22, 1999, at A15 (advertisement number two in a series on economic globalization for The Tuming Point Project, http:/www.turnpoint.org) ("With the emergence of the World Trade Organization (WTO), democracy has moved to the back burner. It no longer matters what democratic societies want; what matters is what global corporations want, as expressed and enforced by global trade bureaucracies in Geneva.") The Turning Point project is a broad coalition of environmental, labor, religious, and other disparate groups opposed to globalization. The ads are posted on the group's web site. 
matter, the structures needed to maintain distinctions between the "national" and the "foreign." This fact should have profound implications for trade laws and policies, which are still anachronistically premised on a clear distinction between what constitutes "national" corporations and "national" products versus "foreign" corporations and "foreign" products.

Yet, the nationalist response to these developments is merely to reinforce the boundaries of the national at the expense of the international; that is, to make corporations be more national in orientation even while the market is global; or to promote national products even though the national identity of a product is less than clear. Conversely, the internationalist response is merely to proceed along the current globalized order, even expand the boundaries of the international and insist on more liberalization, without regard to the rifts anong groups within and among nations nor the antitrade, anti-international backlash ${ }^{19}$ that has deepened as a result of globalization. ${ }^{20}$

Second, current responses to globalization also fail to effectively address the distributional fault lines sparked by global transformations. As I argue below, the nationalist tendency to erect barriers to international economic movements is counterproductive because it is wealth decreasing for

19. See generally Mark J. Roe, Backlash, 98 Colum. L. Rev. 217 (1998) (discussing how and why productive arrangements might generate political backlash and complicate economic analysis); $G$. Richard Shell, Trade Legalism and International Relations Theory: An Analysis of the World Trade Organization, 44 DuKe L.J. 829, 907 (1995) ("Any governance structure for global trade that focuses too narrowly on maximizing wealth without taking into account distributional consequences is likely to encounter strong, perhaps even violent, resistance from the lowers in the distributional tug-of-war."). Antitrade protests in recent years include the anti-WTO protests in Seattle in November 1999, see The Battle in Seattle, The Economst, Nov. 27, 1999, at 21, the anti-Summit of the Americas protests in Quebec in April 2001, see Alfredo S. Lanier, Unfair? Free Market Is Still the Best Option, CHI. TriB., May 27, 2001, at 1C, and the labor-led antiglobalization protests in Washington D.C. in April 2000 against the China trade bill and other international institutions such as the World Bank and the IMF, see Joseph Kahn, Unions Prepare to Hit the Street in Washington, N.X. TIMEs, Apr. 12, 2000, at A16.

20. A new globalized world where companies could easily move production facilities to lowcrwage countries has meant a "shifting of opportunities for wealth and incomes from the older, richer societies to the poorer ones," William Greider, ONE WorLd, Ready OR NOT: The Manic Logic of Global CAPITAlism 42 (1997), hence a concomitant sense of anxieties among the working and middle classes in the advanced, economically developed world.

Antitrade critics like Greider, however, tend to ignore the benefits to "older, richer" societies that free trade still brings. Free international trade generally benefits people of all countries, whether rich or poor; it benefits consumers, productive workers, workers in competitive sectors, and productive and efficient firms. Trade also pushes a country, rich or poor, either to improve any domestic sector that is economically mefficient and lagging, or in the alternative, to transfer resources to those sectors in which it has a comparative advantage. In the process, there are those who are displaced if they are in an industry that lacks a comparative advantage. The solution is not to succumb to protectionism. Workers displaced could instcad simply be given direct transfer payments or cash compensation. See John 0 . McGinnis \& Mark L. Movsesian, The World Trade Constitution, 114 HARv. L. Rev. 511, 520-25 (2000). For a summary of the positive effects of increased international trade, see JuNICHI GoTo, Labor IN INTERnational Trade Theory: A New Perspective on Japanese-American Issues 82 (1990). See also infra note 84. 
rich as well as poor countries. ${ }^{21}$ On the other hand, the internationalist tendency to disregard the significance of nation and national constituents with territorially based attachments is also counterproductive because it fails to address effectively the fact that in this epoch of globalization, labor is for the most part territorially bound, hence most concretely associated with the nation, while capital is increasingly global, hence less so. The internationalist thus must come up with a response that defends unequivocally the free trade norms of international economic law but at the same time revises, where feasible, international trade rules to allow considerations of legitimate nationally based interests in ways that do not promote economic nationalism or protectiomism.

This Article provides a proposal that would resolve these difficulties. The Article sets forth an alternative to the conventional national and international responses to the postnational economic system. Part I discusses the nationalist and internationalist positions. It highlights the intellectual traditions, characteristic sensibilities, and biases in these two intellectual disciplines and explores the dichotomous responses to globalization each has promoted. Part II frames the nationalist and internationalist debate within the context of globalization in trade, production, and investment. It explores how the global logic of commerce and capital has changed the meaning of "nationality" and the relationship between market and state actors in both economically developed and underdeveloped regions. ${ }^{22}$ In this way, Part II demonstrates that international economic law generally, and U.S. trade law particularly, should be re-evaluated in light of these transformations. Part III proposes a new framework to address and manage the conceptual difficulties involved in defining the "national" in a postnational economic system. This proposal is designed to achieve two objectives: first, to reassess the concept of "nationality" and "national origin" in trade law and second, through this revised understanding of "nationality,"23

21. Robert W. McGee, An Economic Analysis of Protectionism in the United States with Implications for International Trade in Europe, 26 GEO. WASH. J. INT'L L. \& ECON. 539,550 (1993) ("[P]rotectionism raises prices, entrenches inefficiency and destroys more jobs than it saves.").

22. I will use the terms "economically developed," the "North," the "First World," the "industrialized countries," or "rich" countries interchangeably in this Article. "Economically undeveloped," "developing countries," the "Third World," the "South," or "poor" countries will be used interchangeably.

23. As opposed to through the adoption of redistributive tax laws, or through the incorporation of the social compact under United Nations ("U.N.") auspices and stressing a code of conduct for multinational corporations in their labor practices. For a discussion of progressive taxation as a means of addressing the needs of lower-skilled workers in the United States faced with competition from the global economy, see Michael A. Livingston, Blum and Kalven at 50: Progressive Taxation, "Globalization," and the New Millennium, 4 FLA. TAX REV. 731 (2000). While progressive taxation may be appealing if the focus is on the rich and poor in one country, for example the United States, the issue becomes more complicated when international questions are considered to include not just the rich and poor in the United States, but the poor in the developing world. For a discussion of labor and 
to strike the necessary balance between the national and the international, the state and the market.

Part III addresses the need to reassess corporate nationality. Given the ease with which products and technology, capital and corporations cross national boundaries, national labels as traditionally understood can no longer be accurately worn. To the extent that a "national" market can still be accurately identified at all, its identification does not come from the traditional conceptions of a national corporation, but from the one factor $\mathrm{m}$ the production process that is still territorial rather than globally oriented: the national workforce and its ties to the national and local community where it is located. Consequently, companies that meet what I term a "domestic participation" test, that is, substantial participation in the national and local community $\mathrm{m}$ which they conduct their businesses, ${ }^{24}$ should be granted the benefits of nationality (including a newly proposed "participation offset" right), ${ }^{25}$ regardless of whether they are in fact incorporated in that state, whether the seat of management decision inaking is in that state, or whether the majority of their shareholders or directors are nationals of that state. ${ }^{26}$ This revision is designed to bring into the global terrain of international economics the territorially based considerations, such as those represented by the interests of community and labor.

Part III also suggests ways to re-examine product nationality through a reassessment of national origin rules. I propose general guidelines for

trade, see Rorden Wilkinson \& Steve Hughes, Labor Standards and Global Governance: Examining the Dimensions of Institutional Engagement, 6 GLOBAL GovERNANCE 259, 262 (2000).

At the 1999 World Economic Forum in Davos, Switzerland, even the U.N. Secretary-General Kofi Annan issued a rejection of linking trade and labor standards within the WTO, offering the following compact to business instead: the U.N. would "make the case for and maintain an environment which favors trade and open markets." Id. at 266 (quoting UN press relcase SG/SM/6881/Rev.1, Kofi Annan, Secretary-General of the U.N., address to the World Economic Forum, Davos, Switzerland, 1 February 1999).

24. See infra Part III.

25. See infra Part III.A.2. The participation offset right, in brief, would entitle companies deemed domestic under the domestic participation test to be exempt from the payment of rules of origin tariffs as well as those additionally imposed pursuant to the various import relief laws and the so-called unfair trade laws-to the extent that the calculated value of the conpany's domestic participation exceeds the amount of duties owed. From a practical standpoint, a participation certificate denominated with a certain face value could be issued to the company (the value of the certificate would vary depending on the degree of participation of that company). The certificate would be the equivalent of a "free pass," allowing the company to have the freedom to import whichever products it chooses, up to the amount of the certificate, without having to pay tariffs and charges that would otherwise have been owed pursuant to various trade laws. For a discussion of whether this proposal is consistent with General Agreement on Tariffs and Trade ("GATT") obligations, see infra note 255.

26. This proposal accords with recent theories on nationality and citizenship, favoring an interpretation of nationality not formalistically but effectively, "having as its basis a social fact of attachment, a genuine connection of existence, interests and sentiments, together with the existence of reciprocal rights and duties." Nottebohm Case (Liechtenstein v. Guatemala) (second phase), 1955 I.C.J. 4, at 23 (Apr. 6). Corporations that demonstrate a level of participation or embeddedness in the national economy of a state will be granted the benefits of nationality under that state's trade laws. 
rethinking the rules of origin in a way that will foreground distribution concerns more effectively. As Part III makes clear, rules of origin have become so politicized, unwieldy, and convoluted that the profound impact they have on poor countries and high-volume workers in rich countries is hidden by a facade of technical and seemingly innocuous details. In my sketch of an alternative set of origin rules, I emphasize the ways in which the rules could be revised (1) to reflect more accurately the postmanufacturing economy and (2) to spread the benefits of international trade more evenly. The critique and proposal for reform are meant to be applicable to the international trading system as a whole, although I intend to focus on the United States merely for purposes of illustration.

Reassessing the concept of nationality along the lines I propose is necessary to address, on a practical level, the fact that nationality has been muddled by globalization. At the same time, by conferring the grant of domestic nationality on any global corporation that demonstrates a level of participation in the national economy, the proposal achieves the additional objective of bringing into focus a balance between the global and the local, the international and the national, the market and the state, capital and labor-without favoring either unchecked globalization on the one hand, or economic nationalism and protectionism on the other hand. Using a revised understanding of "nationality," I argue for a return to the national and the relevance of place in a way that is not antimarket and anti-international.

\section{I \\ NATIONALISM AND INTERNATIONALISM}

A thorough study of nationalism and internationalism, and of each discipline's history and development, is beyond the scope of the Article. Instead, my aim in this Part is merely to highlight the competing sets of ideas that give each discipline its respective zeitgeist or characteristics. Nationalism and internationalism have long vied for intellectual dominance. ${ }^{27}$ Nationalism is itself a contested term subject to multiple meanings and interpretations, ${ }^{28}$ and no unitary definition or description is possible. For

27. E.g.,Wolfgang Friedmann, The Changing Structure of International Law 297 (1964) (identifying in this landmark book two categorical imperatives termed modern state-nationalism and modern internationalism); Nathaniel Berman, Between "Alliance" and "Localization": Nationalism and the New Oscillationism, 26 N.Y.U. J. INT'L L. \& PoL. 449, 449 (1994) (describing the "international legal preoecupation with nationalism"); Thomas M. Franck, Clan and Superclan: Loyalty, Identity and Community in Law and Practice, 90 AM. J. INT'L L. 359, 359 (1996) ("In historical terms, both nationalism and transnational regimes have long bid (sometimes competitively) for the adherence of persons."); S.R. Insanally, Nationalism: No Longer a Domestic Dispute, 26 N.Y.U. J. INT'L L. \& PoL. 439, 440 (1994) ("There is nothing new about the tension... between internationalism, which the United Nations above all personifies, and nationalism.").

28. See generally Lea Brilmayer, The Moral Significance of Nationalism, 71 Notre DAME L. REv. 7, 7 (1995) ("[Nationalism] means such different things to different people. There are many areas 
some, nationalism lies $\mathrm{m}$ the realm of inventions: "'nationalism is not the awakening of nations to self-consciousness; it invents nations where they do not exist." 29 Nations themselves are not natural entities endowed with a predestined physical existence. ${ }^{30}$ Although there has been much intellectual debate over the origins of nationalism and the many historical meanings the term has been associated with, ${ }^{31}$ nationalism now refers to that which is associated with claims surrounding the international system of nation-states or the rights of cultural, historical, or ethnic "nations" aspiring for statehood. ${ }^{32}$ The nation as an entity is constructed around some

of disagreement."); John A. Hall, Nationalisms: Classified and Explained, DaEDALus, Summer 1993, at 1 (" $[\mathrm{N}] \mathrm{o}$ single, universal theory of nationalism is possible."); Symposium, Reconstructing Nations and States, Daedalus, Summer 1993. For historical accounts of nationalism, see BenEDICT anderson, Imagined Communities: Reflections on the Origin and Spread of Nationalism (rev. ed. 1991) and Eric Hobsbawi, Nations and Nationalism Since i780: Programme, Myth, REALITY (1990).

29. Hall, supra note 28, at 4 (quoting ERNEST Geller, Thought AND Change 169 (1964)).

30. ERNest Gellner, Nations and Nationalism 49 (1983). For Gellner, it is inevitably difficult to define a "nation," because the sociological attributes that make up the essence of "nation," common language, religion, ethnicity, are themselves unfixed. Id. at 49 ("Nations are not inscribed into the nature of things, they do not constitute a political version of the doctrine of natural kinds. Nor were national states the manifest ultimate destiny of ethnic or cultural groups."). Gellner was highly critical of Hegel's assertion that it is the destiny of nations to evolve into states. CARLtoN J. H. HAYes, THE Historical Evolution of Modern Nationalism 159 (1931) (describing the demands in Europe "that each nationality should be a political unit under an independent constitutional government which would put an end to despotism, aristocracy, and ecclesiastical influence"); GEORG W. F. HEGEL, LeCTURES ON THE PhILOSOPHY OF WorLd History 134 (H. B. Nisbet trans., 1975) ("Nations may have had a long history before they finally reach their destimation-i.e. that of forming themselves into states....").

Between nation versus state, "the term nation or tribe suggests an affinity group that has placed certain values high on its agenda: shared genealogical origins, language and historic myths, as well as cultural and, perhaps, religious compatibility." Franck, supra uote 27, at 362. States refer to a more politically based form of association than one based on commonalities from past history. In this sense, many states are not nation-states in the sense that they are multinational, for example, India, Canada, Nigeria, and Switzerland. When the "nations" within the state wish to free themselves from the state, for example, "nation" is not interchangeable with "state" but rather, conflicts with "state." Before the World War I peace and minorities treaties, see infra notes $42-47$, international law, with its statist foundation, was reluctant to recognize "nations." See, e.g., Nationality in International Law, 28 TRANSACTIONS OF THE GROTIUS SOC'Y 151, 151-52 (1943).

The word "Nationality" does not mean what it says, nor does it say what it means. Etymologically it would mean the condition of belonging to a nation, of being a national. In International Law "nations" are an unknown quantity... The word "national," if used in International Law, has a technical meaning... [and] means a member or a subject of such a State.

Id.

31. HobsBawM, supra note 28 , at $16-24$ (noting the term "nation" has been used in reference to nonstate identifications, such as guilds, corporations, feudal estates).

32. FRIEDMANN, supra note 27, at 21 ("More and more, from the sixteenth to the early twentieth century, the national state, in many cases coalescing from the older and smaller entities of dukedoms, principalities, and city republics, became the sole source of legal power and the exclusive focus of political allegiance."). Nationalism in its current modern incamation can be traced to the Wilsonian post-World War I world composed of "people" who have a right to self-determination and by implication their own nation-state. See WoODRow WiLson, The Fourteen Points Address (1918), reprinted in 1 WAR AND PEACE 155 (1970); Lori Fisler Damrosch, Nationalism and 
common mooring, whether of language, ethnicity, religion, culture, or some other essential characteristic ${ }^{33}$ upon which the state's "homogenizing project" ${ }^{34}$ can be established. Nationalism in its simplest and most general meaning may mean "simply that one identifies with the claims of one's nations and one's co-nationals, and takes them as one's own."35

By contrast, internationalism is generally built around a different set of preoccupations. In the United States especially, internationalism has been linked to a liberal framework of cosmopolitanism. ${ }^{36}$ Unlike the nationalist whose identification is with the nation, the cosmopolitan's

Internationalism: The Wilsonian Legacy, 26 N.Y.U. J. INT'L L. \& PoL. 493, 493 (1994). John Maynard Keynes was particularly distressed at the balance struck in the Trcaty of Versailles between nationalism and internationalism. See JOHN MAYNARD KEYNES, $A$ Revision of the Treaty, reprinted in 3 The Collected Writings of John Maynard Keynes 1, 8 (Royal Econ. Soc'y Ed., 1971). Keynes commented:

The Wilsonian dogma, which exalts and dignifies the divisions of race and nationality above the bonds of trade and culture, and guarantees frontiers but not happiness, is deeply embedded in the conception of the League of Nations as at present constituted. It yields us the paradox that the first experiment in international government should exert its influence in the direction of intensifying nationalism.

Id.

33. Brilmayer, supra note 28 , at 10 ("There is also controversy about what exactly the defining characteristic of a nation is. A nation is an entity that is fairly homogeneous with respect to some particular variable-it is a community that shares some attribute-but it is difficult to say precisely which attribute that should be. The usual candidates are language, religion, ethnicity, culture, and race; but for every potential defining characteristic, counterexamples can be found.").

34. Katherine Verdery, Whither "Nation" and "Nationalism", in DaEdalus, Summer 1993, at 37,43 .

35. Brilmayer, supra note 28 , at 8 .

36. David Kennedy, The Disciplines of International Law and Policy, 12 LEIDEN J. INT'L L. 9 , 22-25 (1999); Anne-Marie Slaughter Burley, Nationalism Versus Internationalism: Another Look, 26 N.Y.U. J. INT'L. L \& POL. 585, 585 (1994). As Professor Kennedy notes:

one generally does not find in the United States... international lawyers who are also nationalists. International law in the United States after 1945 provided a congenial intellectual home for a large number of immigrants, among them European and Jewish refugees, whose American patriotism was cosmopolitan rather than jingoistic and who have been among the field's strongest intellectual leaders.

Kennedy, supra, at 23; see also id. at 11 ("Legal internationalists in the United States for most of the last 50 years have linked their status to the reputational ups and downs of a broadly libcral cosmopolitanism ....").

Between the two, internationalism, rather than nationalism, is generally more friendly to the spirit of cosmopolitanism. Writing about a universal international order composed of a cosmopolitan and republican federation of liberal states governed by law, Immanuel Kant, for example, rejoiced in the coming of a Weltbürger (citizen of the world) and denounced "the demand of fools in Germany for national pride." Hans Kohn, The Idea of Nationalism: A Study of Its Origins and Background 401 (1944) (citing Kant's Handschriftlicher NaChlass, No. 1099, at 489); Linda Bosniak, Citizenship Denationalized, 7 IND. J. Global Leg. Stud. 447, 494-95 (2000). Bosniak argued:

The ethical cosmopolitan view, in its classical form, rejects particularist loyalties ...; it is a perspective committed to the well-being of humanity at large, rather than any particular community of persons.... In such a view, therefore, grounding one's solidarity in the nation-state is unacceptably narrow and parochial. 
"allegiance is to the worldwide community of hunian beings." ${ }^{.37}$ To the internationalist, nationalism is the "alien," the "other" whose unruly nature and primitive urges are to be tained and contained by, or managed within, a modern and rational international order. ${ }^{38}$ Internationalism associates nationalism with "particularism and parochialism," and proclaims itself to be allied with "universalism and cosmopolitan sophistication." cosmopolitanism that underlies the international project has meant an overall preference for international or multilateral over bilateral or unilateral approaches to problein solving..$^{40}$ At the same time, even while fearing the explosive forces of nationalism, internationalism also recognizes the need to include and simultaneously taine, to appease and simultaneously shape nationalist aspirations and demands by subjecting them to international law and international legal authority. ${ }^{41}$ Indeed, for almost two hundred years, international law has struggled to develop an effective framework of internationalist responses to nationalist conflicts through a variety of legal techniques to harness nationalisin and contain sovereignty, such as

37. Martha C. Nussbaum, Patriotism and Cosmopolitanism, in FOR LOVE OF COUNTRY, supra note 17, at 4. Cosmopolitanism has roots in the ancient Greek Stoics who favored a community that "is truly great and truly common, in which we look neither to this corner nor to that, but measures the boundaries of our nation by the sun." Id. at 7 (citation omitted). Cosmopolitanism is also defined as "[t]he belief in, and pursuit of, a style of life which... [reveals] acquaintance with, and an ability to incorporate, the manners, habits, languages, and social customs of cities throughout the world." ROGER SCruton, A Dictionary of Political Thought 100 (1982). Jeremy Waldron characterized a cosmopolitan as someone who does not secure his or her sense of identity by deeply entrenched moorings to any particular or bounded subset of place, culture, or tradition. Jeremy Waldron, Minority Cultures and the Cosmopolitan Alternative, 25 MiCH. J.L. REFORM 751 (1992). For a classic denunciation of the notion of world citizenship, see HANNAH ARENDT, MEN IN DARK TIMEs 89 (1968) ("A world citizen, living under the tyranny of a world empire, and speaking and thinking in a kind of glorified Esperanto, would be no less a monster than a hermaphrodite.").

38. In a celebrated work, Professor Haus Kohn described nationalism thus:

Its roots seemed to reach into the dark soil of primitive times and to have grown through thousands of hidden channels of nnconscious development, not in the bright light of rational political ends, but in the mysterious womb of the people, deemed to be so much nearer to the forces of nature.

KoHN, supra note 36, at 331; see also Nathaniel Berman, "But the Alternative Is Despair": European Nationalism and the Modernist Renewal of International Law, 106 HARv. L. Rev. 1792, 1798, 1803 (1993) (describing the post-World War I conceptual framework as one designed to strike "a paradoxical "alliance' between turbulent nationalist passion and a newly autonomous international law" because "'[p]eoples and nationalities' were viewed as seething cauldrons of unpredictable forces and passions, rather than as sources of simple and rational first principles"). For the internationalist, the national is primal and the international rational; "if faced with a choice between reason and belief, law and politics, the secular and the sacred, to choose the first term is to build the international, to choose the second is to reinforce the national." Kennedy, supra note 36, at 93.

39. Slaughter Burley, supra note 36, at 585.

40. Keunedy, supra note 36, at 23; Slaughter Burley, supra note 36, at 586.

41. See, e.g., Berman, supra note 38, at 1803 (discussing how the interwar lawyers "attempted to rejuvenate law by opening it up to the vital energy of nationalism, while reshaping nationalism by endowing it with legal form"); see also HaNS KELSEN, PRINCIPLES OF INTERNaTIONAL Law 446-47 (1952) (viewing internationalist as defending "internationalism and pacifism" over "natioualism and imperialism"). 
self-determination, ${ }^{42}$ international minority protections, ${ }^{43}$ internationalization through international administration, ${ }^{44}$ supranational legal integration, ${ }^{45}$ mandates, ${ }^{46}$ and universal human rights. ${ }^{47}$

42. WiLson, supra note 32, reprinted in 1 WAR AND PEACE 159 (1970). One solution to address the collapse of the European empires was to create "national" states. The creation of a Polish state from areas with Polish populations was addressed in Wilson's Thirteenth Point. See also Damrosch, supra note 32, at 493 ("Wilson gave expression to the nationalist aspirations of peoples around the world, through his endorsement of the principle of self-determination. He also initiated the first institution that had as its objective the organization of the international community to apply concerted power in support of universal values.").

43. The redrawing of the European political map after World War I inevitably created minority groups within the territorial borders of the new states. These new states were compelled to sign minority protection treaties or to make declarations guaranteeing rights for their minority groups, including civil rights for all and specific cultural, educational, and lingnistic autonomy rights for minority group members. See generally INIs L. Claude, JR., National Minorities I6 (1955). There were other attempts to administer minority identity within states. For example, in territories transferred from German to Polish sovereignty, German nationals were to acquire Polish citizenship. However, the plebiscite principle allowed German nationals over eighteen years of age to opt for German nationality after two years. In deference to Poland's sovereign powers as a state, Poland was allowed to refuse citizenship to certain residents of the new Polish territories. And Polish citizenship could be granted to certain Poles outside the territory of Poland. Treaty of Versailles, June 28, 1919, art. 91, 225 Consol. T.S. $188,240-41$.

44. When Britain relinquished its mandate over Palestine in 1947, the U.N. General Assembly adopted Resolution 181, which provided for the partition of the territory and the internationalization of Jerusalem. Jerusalem was to be placed under the administration of the U.N. Trusteeship Council, with the following plans for the implementation of an international solution: the creation of two states, one Arab, one Jewish, with self-determination rights; guarantees of minority protection for Jewish and Arab minorities in the new states; supranational integration through the "Economic Union of Palestine," overseen by Arab, Jewish, and U.N. representatives; and internationalization subject to plebiscite review by the residents after ten years. See Berman, supra note 38, at 1795-96.

45. Between 1919 and 1921, the area known as Upper Silesia, the territory divided between Poland and Germany, was placed under international tutelage providing for temporary unity of the region under a fifteen-year complex legal regine, which included the following arrangements: the imposition of a plebiscite, with an Interuational Commission conducting the vote and a Committee of Experts and the Conference of Allied Ambassadors interpreting the results; the establishment of a supranational regime that reflected parts of the two sovereigns' legal systems; extensive provisions for minority rights; the creation of a quasi-international legal personality to residents of Upper Silesia; and the establishment of mixed local and international tribunals. See generally Berman, supra note 38, at 1893-98.

The formation of the European Economic Community and the European Union might constitute another example. See Mann, supra note 2, at 120-28.

46. International law responded to the collapse of European empires by formal rccognition of national states and minority rights protections. See supra notes $43 \& 45$. The non-European possessions of the collapsed empires, deemed not yet ready for statehood, were subjected to the mandate system. Treaty of Versailles, supra note 43, at 203. The mandate system was divided into Class A, B, and C mandates. Class A mandates were coinposed of the former territories of the Ottoman Einpires. These former territories were deemed to "have reached a stage of devclopinent where their existence as independent nations can be provisionally recognised subject to the rendering of administrative advice and assistance by a Mandatory until such time as they are able to stand alone." Id. at 203. Accordingly, the administering authorities had only nominal supervisory power over Class A mandates. Class B mandates were made up of the former German colonies in Central Africa, and the administering authorities had greater supervisory power over them. Other former German territories in Africa and the Pacific were deemed Class $\mathrm{C}$ mandates and part of the territory of the mandatory, "subject to the mandatory municipal law." Ramon E. Reyes Jr., Nauru v. Australia: The International Fiduciary Duty 
The contrasts between nationalism and internationalism have become even more stark as a result of globalization. As Part II will show, one might characterize globalization as a hyper state of internationalization. ${ }^{48}$ Thus it is not surprising that nationalism and globalization might be viewed as each other's antithesis. ${ }^{49}$ For nationalists, globalization is associated with an inevitable "move from public to private. The state will be weaker and commerce will be strengthened"50 in ways that will result in the increasing homogenization of social and economic relations ${ }^{51}$ and accordingly, the dilution of national distinctiveness and control. The nationalist agenda thus includes a vigorous defense of "a basic reality-that a major value of human life is a rootedness in place." 52

and the Settlement of Nauru's Claims for Rehabilitation of its Phosphate Lands, 16 N.Y.L. ScH. J. INT'L \& CoMP. L. 1, 16 (1996).

47. The Versailles system had aimed towards the preservation of sovereignty, national identities, and individual and minority rights. The system eventually collapsed and the international minority protection system was replaced with the notion of universal individual human rights. Josef L. Kunz, The Present Status of the International Law for the Protection of Minorities, 48 AM. J. INT'L L. 282, 284 (1954).

48. Or, as antiglobalization critics may characterize it, "globalization is merely capitalism writ large." Globalisation and Its Critics, THE EconomIs, Sept. 29, 2001, at 5.

49. Franck, supra note 27, at 362 (discussing the "thesis of nationalism and antithesis of globalization"). Some have noted the dangers should nationalism feel itself diminished by the dominance of globalization. See Lawrence M. Friedman, Borders: On the Emerging Soeiology of Transnational Law, 32 STAN. J. INT'L L. 65, 88-89 (1996) ("Modern nationalism and ethnocentrism may be particularly virulent and dangerous, precisely because group identity is constantly threatened by the forces released by nodernity. These powerful forces of globalization include mass communications, mobility, and tourism, and the rapid spread of fashions and tastes."); Edith Brown Weiss, The Rise or the Fall of International Law?, 69 FordHAM L. Rev. 345, 348 (2000) ("As integration and globalization increase, there is sinultaneously a growing fragmentation within States and strong pressures for decentralization of decision-making. Ethnicity, nationalism, and the need for personal affiliations and satisfaction push toward fragmentation and decentralization.").

50. Kennedy, supra note 36, at 40; see also Zillah Eisenstein, Stop Stomping on the Rest of Us: Retrieving Publicness from the Privatization of the Globe, 4 IND. J. GLOBAL LEG. STUD. 59, 63 (1996). Eisenstein cominented:

Because privacy always exists in relation to publicness, and because they shift and conflict with each other sinultaneously, the privatization of the public realm has created a crisis for both realms.... If a notion of public is gone, how does one live outside the self? Transnational capital needs privatization of multiple publics. So neocons revise democracy for global marketing.

Id.; Elisabeth Lasch-Quinn, Democracy Should Not Have Losers, 9 Minn. J. Global. TrADE 589, 592 (2000) (describing proglobalization internationalism as being devoid of "any conception of a world beyond the market-the political or civic or cultural world in which ideas, beliefs, traditions, even innovations have ineaning beyond their salability").

51. Suzanne Berger, Introduction to National Diversity and Global Capitalism 1 (Suzanne Berger \& Ronald Dore eds., 1996) (criticizing the "convergence across nations in the structures of production and im the relations antong economy, society, and state"); Robert Wolf, The Regionalist Answer, 9 Minn. J. Global Trade 610, 621 (2000) (describing "globalization of world trade and culture [as] a process of homogenization which an increasing number of people perceive as soulless and dehumanizing" and decrying "world-wide monoculture now being created by the corporations"). Id.

52. John Miller, Globalization and its Metaphors, 9 Minn. J. Global Trade 594, 598 (2000); see also Herman E. DALY \& JoHn B. CoBb, JR., For the COMmon Good 233-35 (1989) (arguing that global trade erodes local cominurities and promotes an imagimed and nonexistent "world community"). 
Fear of globalization as a commodity-centered model ${ }^{53}$ of social and economic arrangement is exacerbated by the apparent cozy relationship that seems to have been struck between globalization and international economies. "Many see a lag between the bold new world of international commerce, communications, regulation, and policy which has adapted to life in a global village and the international political institutions which have not." ${ }^{.54}$ In this way, globalization is equated with erosion of sovereignty and governmental control..$^{55}$ Sovereignty at the nation-state level is thus all the more necessary to defend against the global economic system and "the Golden Straitjacket" states must increasingly accept as a precondition to attracting capital. For many countries, wearing the Golden Straitjacket has meant, as nationalists bemoan, "your economy grows and your politics shrinks,"

53. Paul B. Thompson, Globalization, Losers and Property Rights, 9 MinN. J. Global Trade $602,606(2000)$.

54. Kennedy, supra note 36, at 39; Keith E. Whittington, Dismantling the Modern State? The Changing Structural Foundations of Federalism, 25 Hastings Const. L.Q. 483, 511 (1998) ("[G]lobalization of the economy has meant that there is no escaping the market. Interstate corporations and the consolidation of the domestic economy threatened to outstrip the capacity of the states or the market to control them ....").

55. Whittington, supra note 54 , at 512 ("[G]lobalization has weakened governmental sovereignty, the perceived governmental ability to make and enforce autonomous decisions."). Additional charges against globalization include assertions that it erodes democratic values. Wolf, supra note 51, at 614 (condemning the "Inegalithic" corporations); Elisabeth Lasch-Quinn, supra note 50 , at 593.

56. Friedman, supra note 10, at 86. "The Cold War had the Mao suit, the Nehru jacket, the Russian fur. Globalization has only the Golden Straitjacket." This means that for countries to generate the growth necessary to embark on a program of economic development, they have to link with and engage the global market and its rules:

[M]aking the private sector the primary engine of its economic growth, maintaining a low rate of inflation and price stability, shrinking the size of its state bureaucracy, maintaining as close to a balanced budget as possible, if not a surplus, eliminating and lowering tariffs on imported goods, removing restrictions on foreign investment, getting rid of quotas and domestic monopolies, increasing exports, privatizing state-owned industries .... Id. at 86-87.

57. Id. at 87. Once plugged into and linked with the global market, in other words, states are expected to manage their economies according to the rules of the international market-to wear the global straitjacket. Those who do not have to deal with the consequences of capital flight. In India, even the coalition led by the nationalist Bharatiya Janata Party, which campaigned on a Hindu-first platform, conceded that "[ $\mathrm{t}]$ he priority is to build a national consensus on the acceptance of global capital, market norms and whatever goes with it. ... You have to go out and compete for investments." Jonathan Karp, India's BJP Is Shifting Priority to the Economy, WALL ST. J., Oct. 7, 1999, at A21. Similarly, even leftof-center parties in Europe have had to accept the straitjacket of globalization, prompting critics to ask: After all, "what is the point of 'Europe', if Europe is turning out to be just another United States?" What Is Europe?, THE EcoNomisr, Feb. 12, 2000, at 15. Korea's Prime Minister in the mid-1990s, Lee Hong Koo, said, "The big decisions today are whether you have a deınocracy or not and whether you have an open econoiny or not. Those are the big choices. But once you've made those big choices, politics becomes just politicaI engineering to implement decisions in the narrow space allowed you within this system." FrIEDMAN, supra note 10, at 89; Cf. Globalisation and Its Critics, supra note 48, at 18-19. 
national sovereignty. ${ }^{58}$ Increasingly, nationalists defend the national project as a populist movement that speaks not an abstract, universal language but rather, the people's language- "the emotionalism, the vulgar populism, the highly-coloured romanticism of most nationalist ideology (all the things imtellectuals have always held their noses at)."59

To further complicate matters, for nationalists, the "marketization of international law" ${ }^{\prime 60}$ has created an international domain that is not only global and antinational, but also culturally American and therefore, by that very fact, additionally problematic. ${ }^{61}$ As globalization spreads, the nationalist opposition to globalization on economic grounds has taken on an additional cultural element: "We have our own culture, our own values, and we will do it our own way at our own pace." N2 Nationalism thus proclaims itself to be "against civilization being disseminated out and downwards from the appropriate centers." ${ }^{363}$ Nationalism is a movement not just to liberate people whom imperial powers had forced to live together in empires but also to oppose the self-serving ideology of "big battalion" states that

58. The global market in general and the WTO in particular are viewed as stealthy, antidemocratic, sovereignty-eroding bodies. Globalization vs. Nature, supra note 18; see also Patti Goldman, The Democratization of the Development of United States Trade Policy, 27 CorNell INT'L L.J. 631, 634-43 (1994); Robert F. Housman, Democratizing International Trade Decision-Making, 27 CORNELL INT'L L.J. 699, 734-37 (1994). For a thoughtful examination of the WTO and its impact on sovereignty and democracy, see Kal Raustiala, Sovereignty and Multilateralism, 1 CH1. J. INT'L L. 401, 410-19 (2000).

59. Tom NaIrn, The Break-up of Brutain 354 (2nd exp. ed. 1977).

60. Kennedy, supra note 36, at 34 .

61. The Marxist cultural critic Fredric Jameson has called the inerger of economic globalization and culture a "postmodern hyperspace" that expands without regard to territorial boundaries. Fredric Jameson, Postmodernism, or the Cultural Logic of Late Capitalism, NEw LEFT REv., July-Aug. 1984, at 53; see also Fredric Janeson, Marxism and Postmodernism, NEw LEFT REv., July-Aug. 1989, at 31. Prominent Neo-Marxists like Toin Nairn now associate cosmopolitamsm and internationalism with the self-serving elitist ideology of "big battalion" states that hide their particularistic agenda of infinite capital accumulation behind a facade of universalistic norms, and more specifically, behind the agenda of the American empire. Nairn, supra note 3, at 157, 161. According to Nairn, the recent unrestrained movements of production and capital transnationally have resulted, for poor countries, in "[p]rogress in the abstract [and] domination in the concrete," and domination as "Anglicization or Frenchification.... [or] more globally: 'Westernization' or 'Americanization." NArRN, supra note 59 , at 338.

62. FRIEDMAN, supra note 10, at 90; see also Frank E. Mauning, Reversible Resistance: Canadian Popular Culture and the American Other, in THE BEAVER BITES BACK? American Popular Culture in Canada 4, 4 (David H. Flaherty \& Frank E. Manning eds., 1993). Manning quotes Margaret Atwood in the following:

Canada as a separate but dominated country has done about as well under the U.S. as women, worldwide, have done under men; about the only position they've ever adopted towards us, country to country, has been the missionary position, and we were not on top. 1 guess that's why the national wisdom vis-à-vis Them has so often taken the form of lying still, keeping Id. your mouth shut, and pretendimg you like it.

63. Nairn, supra note 3, at 160. 


\section{employ universalistic norms against local cultures. ${ }^{64}$ Fearing that globaliza-} tion is now the vehicle for cultural imperialism, the nationalist struggle adds local culture to the long list of ideals to be defended. ${ }^{65}$

Internationalists, on the other hand, do not condemn globalization, transnationalization, or postnationalization ${ }^{66}$ on a wholesale scale, but

64. Nationalists are "protagonists of medieval particularism" against the abstractions of universality, "favoring [n]ot the implacably prescribed common sense of internationalism, but the nonlogical, untidy, refractory, disintegrative, particularistic truth of nation-statcs," Nairn, supra note 3, at 157,158 , precisely because of the "thinness of cosmopolitanism and the crucial humanizing role played by identity politics in a deracinated world of contracts, markets, and legal personhood." Barber, supra note 17, at 30. In repudiating the notion of a cosmopolitan ethics, Hannah Arendt proclaimed that a citizen "is by definition a citizen among citizens of a country among countries. His rights and duties must be defined and limited, not only by those of his fellow citizens, but also by the boundaries of a territory." ARENDT, supra note 37, at 81.

65. See Richard A. Falk, Culture, Modernism, Postmodernism: A Challenge to International Relations, in Culture and InTERnational Relations 268 (Jongsuk Chay ed., 1990) (commenting that the rhetoric of globalization tends to "disguise patterns of imterstate hegemony, especially as between Europe and the rest of the world"); L. Amede Obiora, Feminism, Globalization, and Culture: After Beijing, 4 IND. J. GLOBAL LEG. STUD. 355, 380-81 (1997). Obiora stated:

Marginalized by exposure to an onslaught of conditions of modernity, the market economy, and imperialistic transnational entcrprises, distinct cultural groups tend to view themselves as being under pressure to demonstrate their ritual purity and allegiance to traditional high culture. In certain quarters, changes emanating from globalization are suspiciously perceivcd as Trojan horses in service of cultural imperialism. As such, they are countered with fervent expressions of nationalism....

Id.; Elisabeth Lasch-Quinn, supra note 50, at 593, 590 (decrying support by "global marketcrs," for "globalization, 'the American steamroller,' which decimatcs languages, traditions, and the environment at whim").

66. See infra notes $67-76$ and accompanying text. Terms such as globalization, internationalization, transnationalization, postnationalization, and even denationalization have been used to describe the process by which activities which were once taking place within national borders are now taking place beyond national borders. See generally R.J. BARRY JONES, GLOBALISATION AND INTERDEPENDENCE IN THE INTERnational POLITICAL ECONOMY 3 (1995). Goods, financial instruments, capital, services, technology, and even culture itself, are being exchanged across national borders. Each of the terms above describes something about that process, although each term may connote something specific about the character of and consequences to this phenomenon.

The term "globalization" is generally associated with various forms of linkages among businesses and markets across and without regard to national borders and usually connotes some erosion of the national, provoking questions about the meaning of democracy, participation, and sovereignty.

"Internationalization" or "transnationalization" may simply mean "cooperative activities of national actors," bilaterally or multilaterally; see Gordon R. Walker \& Mark A. Fox, Globalization: An Analytical Framework, 3 IND. J. GLOBAL LEG. STUD. 375 (1996), so that the national is not necessarily diminished. See also Anne-Marie Slaughter, The Real New World Order, 76 ForEIGN AFFAIRs 183, 184 (1997) ("The state is not disappearing, it is desegregating into its separate, functionally distinct parts. These parts - courts, regulatory agencies, executives, and even legislatures-are networking with their counterparts abroad, creating a dense web of relations that constitutes a new, transgoverninental order.").

"Postnationalization" implies a shift, conceptually and paradigmatically, from the national to something beyond the national, although the term does not necessarily implicate a shift in the relationship between the state and the market, as in "globalization," but rather a shift in the relationship between the state and other nonmarkct, non-state entities, such as nongovernmental organizations in the fields of human rights and the environment. See, e.g., Richard J. BarNet \& JoHN Cavanaugh, Global Dreams: Imperial Corporations and the New World ORDER 429-30 (1994); Richard Falk, The Making of Global Citizenship, in Global Visions: BEYOND THE NEW WORLD ORDER 39, 
rather defend internationalization and the international order in various ways and at various levels. In the economic field, internationalists, as compared to nationalists, are also more or less coinfortable with an international system that extends beyond the national and nationalism, governs "from a space beyond culture," politan order ${ }^{63}$ against the political interference of the state. ${ }^{69}$

47-48 (Jeremy Brecher et al. eds., 1993); Paul Wapner, Politics Beyond the State: Environmental Activism and World Civic Politics, 47 WORLD PoL. 311, 312-13 (1995).

"Denationalization" is used less, but refers to the primarily economic phenomenon, in which the national is diminished. See SASkia Sassen, Losing Control? Sovereignty in aN Age of Globalization 33 (1996) ("[E]conomic globalization has contributed to a denationalizing of national territory....").

"Transnationalization," "postnationalization," and "denationalization" have also been used to describe wholly noneconomic developments, to capture the emergence of crossnational or subnational identities to give rise to a new meaning of citizenship that is multiple and transterritorial. See, e.g., Yasemin Nohuglu Soysal, Changing Parameters of Citizenship and Claims-Making: Organized Islam in European Public Spheres, 26 THEORY AND Soc'y 509, 513 (1997) (postnational citizenship); Peter J. Spiro, The Citizenship Dilemma, 51 STAN. L. REv. 597 (1999) (book review).

67. Kennedy, supra note 36, at 82; see also Joel Richard Paul, Cultural Resistance to Global Governance, 22 Mich. J. INT'L L. 1 (2000). Paul commented:

The whole legal structure of the free trade norm rests on a rational economic model.... Cultural claims threaten that rationality argument. Cultural claims derive from sentiment, nostalgia, imsecurity; they are rooted in non-rationality. To protect the rationality of the market from the non-rationality of nationalism and culture, the international community rejects cultural exceptions.

Id. at 80 . For a critique of the internationalist assumption that the mternational is acultural, see David Kennedy, Background Noise? The Underlying Politics of Global Governance, HaRv. INT'L Rev., Summer 1999, at 52 [hereinafter Background Noise?] ("Common but mistaken ideas-like the idea that international governance is separate from both the global market and from local culture, or is more a matter of public than of private law-sharply narrow the sense among foreign-policy professionals of what is possible and appropriate for foreign policy.").

68. Karl Marx was one of the earlier critics of the international market's claim to cosmopolitanism:

The bourgeoisie has through its exploitation of the world-market given a cosmopolitan character to production and consumption in every country.... [T]t has drawn froin under the feet of industry the national ground on whieh it stood. All old-established national industries have been destroyed or are daily being destroyed. They are dislodged by new industries, whose introduction becomes a life and death question for all civilized nations, ... industries whose products are eonsumed, not only at home, but in every quarter of the globe.... In place of the old local and national seclusion and self-sufficiency, we have intercourse in every direction, universal inter-dependence of nations.

Karl Marx, Manifesto of the Communist Party, reprinted in THE MARX-Engels READER 476-77 (Robert C. Tucker ed., 2d ed. 1978).

Similarly, today's critics argne that the supposed cosmopolitanism of market-driven globalization entails "a perspective of the whole [world] that is totally oblivious to the ethical imperatives of human solidarity," Richard Falk, Revisioning Cosmopolitanism, in FOR Love of COUNTRY supra note 17 at 53 , and is in no way related to the cosmopolitanism espoused by those like Martha Nussbaum, supra note 37; see also Falk, The Making of Global Citizenship, supra note 66, at 44.

69. For example, the European common market has been depoliticized:

In a technocratic private market, the locus for political choice is less opened up than it is rendered invisible. Take the European Union, whose political decision-making always seems to take place "elsewhere"... The idea of a "government" promoting a "program" has been replaced by the enlightened management of prosperity.... EU policy managers[, for example,] treat the transitional economies of Central and Eastern Europe less as a set of 
Globalization of trade and investment, the free movement of goods and services, and, increasingly, of capital, across national borders, are generally compatible for private internationalism. ${ }^{70}$ Even though some internationalists would like to see a superinternational regulatory structure-a globalized New Deal, so to speak-instituted to manage these changes, they are not opposed per se to the rise of transnational economic activities. ${ }^{71}$ Indeed, international economic law has over the years aimed to build an international liberal regime of WTO rules to overcome a protectionist national regime of local rules ${ }^{72}$ more susceptible to capture by parochial political interests. ${ }^{73}$ Recently, in an effort to create a dispute settlement system that is based less on diplomacy or power and more on rules and law, the Dispute Settlement Body of the WTO was empowered to issue decisions that are binding unless the Dispute Settlement Body, including the winning party, votes unanimously to overturn it. ${ }^{74}$ To private

political exclusions and choices than as the technical management of different natural stages of development.

Background Noise?, supra note 67, at 53.

70. There is a set of characteristics that define private internationalism:

International economic law ... is defined not by the subjects it governs, but by its regulatory terrain-the law, of whatever origin, which governs international economic transactions. It mixes national and international law, and is rooted in private law-both national regimes of contract or property and international regimes of private law unification and conflict of laws. We might have called aspects of this field "private international law" some years ago, but the newer phrase "international economic law" embraces the public law institutional machinery of trade law and policy-General Agreement on Tariffs and Trade (GATT), North American Free Trade Association (NAFTA), the European Union, Mercado Comunitario Suramericano (MERCOSUR), and the rest.

Kennedy, supra note 36, at 38-39.

71. See, e.g., Anne-Marie Burly, Regulating the World: Multilateralism, International Law, and the Projection of the New Deal Regulatory State, in Multilateralism MatTers: The Theory and PRAXIS OF THE INsTITUTIONAL FoRM 125 (John Gerard Ruggie ed., 1993); Shell, supra note 19, at 907 (arguing for a "trade stakeholders" model which would allow individual and nongovernmental organization participation in the WTO).

72. International trade legalism allows governments to resist domestic resistance to free trade. For the argument that free trade internationalism is more democratic than domestic protectionism, see generally Robert E. Hudec, "Circumventing" Democracy: The Political Morality of Trade Negotiations, 25 N.Y.U. J. INT'L L. \& Pol. 311 (1993); McGinnis \& Movsesian, supra note 20 (discussing how internationalism of the type manifested in the WTO provides the antidote to naked interest-group politics and donestic rent-seeking at the national level); Jan Tumlir, Need for an Open Multilateral Trading System, 6 THE WORLD ECON. 393, 406 (1983) (arguing the trade system and its "international rules represent a truer expression of the national interest of all the countries concerned than the mass of national [economic] legislation").

73. For a discussion of how interest groups, particularly industries with significant political strength, press for protectionist measures that further their own rather than the national interest, see Robert Z. Lawrence \& Robert E. Litan, Saving Free Trade: A Pragmatic Approach 23-24 (1986); see also Edward John Ray, Changing Patterns of Protectionism: The Fall in Tariffs and the Rise in Non-Tariff Barriers, 8 Nw. J. INT'L L. \& Bus. 285, 290-91 (1987) (discussing how special interest groups worked to block the opening of U.S. markets for exports from poor countries).

74. Understanding on Rules and Procedures Governing the Settlement of Disputes, Final Act Embodying the Results of the Uruguay Round of Multilateral Trade Negotiations, Apr. 15, 1994, art. 16(4), 33 I.L.M. 1 125, 1235 (1994) [hereinafter Understanding on Rules]. The losing party is to comply with the decision. Understanding on Rules art. 21(3). If the losing party does not, the parties are to 
internationalists especially, the idea that conflicts can be "privatized" or "economized"- - that is, cabined in a private, economic sphere-and disagreements among states resolved through a rational regime of "technocratic cosmopolitan governance" consisting of "technocratic means, sound management and trade deals"75 is appealing. Thus, the international is appropriately cosmopolitan and universal, the correct antidote to parochial politics, national controls, political interventions, and other forms of capitulation to organized interest groups. ${ }^{76}$

As one example of the nationalist versus internationalist response to economic globalization, take the case of a Japanese automaker that ships its design components for assembly in its plant in Mexico, and then distributes the finished product to buyers $m$ the Umited States and in other parts of the world. The company, motivated in part by its ability to engage in "wage arbitrage" 77 in Mexico, has chosen to move production from a high-wage to

come up with a "mutually acceptable compensation." Understanding on Rules art. 22(2). And failing that, the winning party may seek authorization from the Dispute Settlement Body to withdraw concessions "equivalent to the level of the nullification and impairment" suffered. Understanding on Rules art. 22(4). The losing party thus could comply with the WTO ruling, by changing the law or practice that had given rise to the complaint, or it could pay damages for noncompliance. Contrast this with the old GATT system, where the losing party could veto dispute resolution panel decisions to keep them from becoming binding. JOHN H. JACKSON, RESTRUCTURING THE GATT SYSTEM 61-65 (1990).

75. Background Noise?, supra note 67, at 54 ("Specialists tend to overestimate the technocratic or apolitical nature of economic concerns, mcluding the independence of econouric development from background cultural, political, and institutional contexts.").

76. See Michael D. Pendleton, A New Human Right-The Right to Globalization, 22 FordHaM INT'L L.J. 2052, 2052-53 (1999) ("Globalization offers a realistic vehicle for escaping from failed nationalism to an expanded concept of global rights and duties.... [Its] economic potential is what gives globalization power even against antagomistic national governments."); see also Wesley A. Caun, Jr., Creating Standards and Accountability for the Use of the WTO Security Exception: Reducing the Role of Power-Based Relations and Establishing a New Balance Between Sovereignty and Multilateralism, 26 YALE J. INT'L L. 413, 414 (2001). Cann quoted Renato Ruggiero, Director-General of the WTO, as follows:

[T] he need is not to discuss whether globalization is a good thing, but to ask ... "what would

be the alternative?" It would be a world divided by economic and political nationalism-a world in which we would go down the road towards power-based relations, mcreased tension and violence, as history has taught us.

Id. at 414-15 n.4; Renato Ruggiero, Reflections After Seattle, 24 FoRdHAM INT'L L.J. 9, 14 (2000) ("Without the WTO, we will go back to a world of national barriers, protectionism, economic nationalism, and confiict. History has repeatedly showed where this road can lead."). The state is all too susceptible to the push and pull of "local politics (of protectiomsm, exchange controls, redistribution, corruption, etc.)..." Kennedy, supra note 36, at 86. International economic rules such as those of the WTO are thus necessary for "bringing law in general to bear on politics in particular, order to bcar on anarchy, reason on chaos, the international on the national." $I d$.

77. GREIDER, supra note 20, at 58; see also Michael Kelly, Globalization: No Pain, No Gain, WASH. PosT, Apr. 25, 2001, at A31 ("[T] he purpose of globalisin is to allow capital to freely chase profits around the world: to allow corporations to make more money by manufacturing their goods in dirt-wage, low-regulation undeveloped countries instead of in high-wage, high-regulation developed countries.... [Thus] [m]anufacturing jobs must migrate from developed countries to undeveloped countries ...."). However, although the desire to engage in "wage arbitrage" is a contributing factor to a company's global expansion, it is not the only one. The economist Lester Thurow noted that the inability to develop skills for a technology-oriented information economy is as significant a threat to 
a low-wage labor market in order to reduce the cost of production and increase its profit margin, and to position its products for preferential treatment by NAFTA.

The ease with which multinational companies move globally sets up the following: a tug of war between workers from the mature industrial economies who are threatened with losing their fifteen-dollar-per-hour jobs and workers from the agrarian, newly industrializing ones who may in fact gain two-or three-dollar-per-hour jobs. ${ }^{78}$ Globalization has shifted certain types of economic activities from one region of the globe to the other. For lower skilled workers in industrial sectors in rich countries, the concern is simply stated: "to what extent has, or will, the pay of low-skilled Americans or French or Germans be set in Beijing, Delhi and Djakkarta rather than in New York, Paris, or Frankfurt?"779 But globalization has also rewarded, whether in rich or poor countries, those workers in the "highvalue" of the global age. The national and international trade regime has crafted radically different responses to these shifts. ${ }^{81}$

In response to the rifts that have arisen between countries (rich and poor) and groups within countries ("high-value" and "high-volume" workers), nationalists and other antiglobalization groups, particularly from rich countries, have generally favored more protectionism against "foreign" companies and "foreign" goods in favor of "domestic" ones (invoking the

high-volume, manufacturing-based workers as is the large pool of low-wage workers in the poorer countries. Lester C. Thurow, The Future of CAPITAlism 166-84 (1996); see also infra note 155. For a discussion of how, according to the Stolper-Samuelson theorem, "free international trade benefits the abundant factor and harms the scarce factor," and the impact this has on U.S.-China trade (or trade between any capital-abundant country and labor-abundant country), see STEven HuSTED \& MrCHAEL MELVin, InTERNational ECONOMics 105, 106-09, 116-17 (5th ed. 2001).

78. Put another way, as then-U.S Trade Representative Micky Kantor reportedly asked his fellow cabinet members in a 1993 meeting: "Who are my clients-American companies or American workers?" Daniel F. Burton, Jr. et al., Multinationals: The 'Who Is Us' Debate, ChaLlenGe, Sept.Oct. 1994, at 33 .

79. Marina Wes, Globalisation: Winners and Losers (Commission on Public Policy and British Business: Issue Paper No. 3 (1996)).

80. Robert B. Reich, THE WORK OF NATIONS 82-84 (1992); see also Joseph Kahn, Unions Prepare to Hit the Street in Washington, N.Y. Times, Apr. 12, 2000, at A16 (discussing the rift between high-tech workers and other union-based workers and the tension between presenting an internationalist image versus a protectionist one for the U.S. Democratic Party). For a discussion of the importance of the new information technology, see also S. REP. No. 104-359 (1996) (recommending the enactment of the Economic Espionage Act of 1996).

81. See generally Sylvia Ostry, The Post-Cold War Trading System (1997). Using an "exit" and "voice" paradigm suggested by Alfred O. Hirschman in ExIT, VoICE, AND LoYALTY (1970), Professor Ostry noted that the United States pursues a strategy of "exit" for displaced U.S. workers, whereby the workers themselves, not the government, are expected to make the necessary adjustments to their own losses sustained as a result of international trade. Workers who may be forced to exit thus oppose trade liberalization. Europe pursues a strategy of "voice," where the government plays an active role in minimizing the costs of adjustment in order to maintain social cohesion, even at the expense of economic efficiency. OSTRY, supra, at 235 . Here, workers may oppose trade liberalization if they believe it will accelerate a loss of voice. 
name of nationalism and sovereignty). As applied to the example above, this could mean keeping out, through quotas or high tariffs, foreign auto components of Mexico-in order to save the jobs of U.S. workers who would otherwise lose their jobs to workers in Mexico. Yet, by overlooking the costs of propping up sunset industries in which rich countries no longer have a comparative advantage, ${ }^{82}$ First World economic nationalists msist on the politics of the local at the expense of aggregate wealth generally and Third World economic development particularly. ${ }^{83}$

Besides the fact that "nationality" has become increasingly blurred, this nationalistic solution is also flawed because it will have the effect of producing allocative inefficiency and decreasing efficiency gains for the richer countries, as well as increasing barriers to trade and developmental possibilities for the poorer countries. The solution to the distributional problem within the rich countries, I argue, should not be one that compounds the distributional problem between poor and rich countries. That engagement in the global economy produces greater total wealth is the basic premise of the international economic system and of this Article. ${ }^{84}$

On the other hand, as I have mentioned, internationalists have emphasized the economic and efficiency benefits of international trade and investment without paying sufficient attention to the pull of the national and the local. The internationalist response to the above example: push for more liberalization, perhaps expand NAFTA to include a Free Trade Area for the whole of Latin America, and allow the rules of trade and the law of comparative advantage to sort out winners and losers. In certain areas already, the boundaries of the international economic regime have been

82. See, e.g., Miller, supra note 52, at 597 (voicing concern for industries such as "steel, petroleum, and agricultural production"). For a discussion of the costs of protectionism, see supra note 21 .

83. The World Bank defines extreme poverty according to a set of "reference lines" of $\$ 1$ and $\$ 2$ per day in 1993 terms. THE WORLD BANK, MEASURING PoverTy, at http://www.worldbank.org/ poverty/mission/up2.htm (last modified Oct. 16, 2000). Openness to trade, not protectionism or isolationism, increases wealth and reduces poverty. See infra note 84.

84. This Article relies on works by liberal trade scholars and accepts that free trade creates wealth for and among nations. See, e.g., JAGDish Bhagwat, PROTECTIONISM (1988). The U.N. concluded in a recent report that "[t]here is now widespread acceptance that, in the long run, the expansion of international trade and integration into the world economy are necessary instruments for promoting economic growth and reducing and eradicating poverty ...." U.N.G.A., REPORT OF THE SECRETARYGeneral to the Preparatory COMM. FOR THE HIGH-LEVEL INTERNATIONAL INTERGOVERNMENTAL Event on Financing for Development 26 (Dec. 18, 2000) (A/AC.257/12).

A number of studies have also shown that growth benefits not just the rich but also the poor. See, e.g., Klaus Deininger \& Lyn Squire, $A$ New Data Set Measuring Income Inequality, 10 WorLD BANK Econ. Rev. 565 (1996); William Easterly, Life During Growth, 4 J. Econ. GrowrH 239 (1999); see also David Dollar \& Aart Kraay, Growth Is Good for the Poor 2 (Development Research Group, the World Bank, March 2001 draft), available at http://www.worldbank.org/research/growth/pdfiles/ GIGFTP3.pdf (concluding, based on an empirical study involving a sample of ninety-two conntries where the median number of growth episodes is three per country, that "on average, within countries, inconies of the poor rise equi-proportionately with average incomes"); Globalisation and Its Critics, supra note 48 , at 10-11. 
expanded to give the international the mechanisms it needs to frustrate national protectionist ambitions. Indeed, free trade norms developed by private international arbiters have increasingly acquired the force of law, granted direct legal effect in domestic courts through the adoption of a number of legal devices. ${ }^{85}$ Economic internationalism, then, is precisely the shield needed to counter the temptation of economic nationalism. For internationalists, "national interest" is but a code word for parochialism and economic protectionism. ${ }^{86}$

There are still other responses that are neither strictly nationalist nor internationalist but a populist mix of the two. Composed of a broad coalition of religious, environmental, organized labor, student, and other ad hoc groups, ${ }^{87}$ this movement has emerged in recent years to oppose economic globalization and the perceived antinational excesses of the WTO ${ }^{88}$ At the

85. Note that a decision issued by the WTO Dispute Settlement Body, though binding as WTO law, does not have to be implemented domestically. See supra note 74 . By contrast, there are now parallel economic regimes that go much further, at least as far as enforcement is concerned, and allow awards by international tribunals to be recognized and enforced by domestic courts with minimal domestic scrutiny. NAFTA's dispute resolution provision, Article 19, for example, "creates a binding, supranational arbitration scheme accessible directly by private business parties through which businesses may overturn final anti-dumping and countervailing duty decisions of domestic trade regulators." Shell, supra note 19, at 887. The Convention on the Recognition and Enforcement of Foreign Arbitral Awards, opened for signature June 10, 1958, 21 U.S.T. 2517, 330 U.N.T.S. 3, creates a system where domestic courts of signatory countries are bound, subject to minimal "public policy" exceptions, to enforce arbitration agreements rendered by private international commercial arbitrators. Similarly, under the International Convention for the Settlement of Investment Disputes ("ICSID"), contracting states may be sued by private parties and must "recognize an award rendered pursuant to this Convention as binding and enforce the pecuniary obligations imposed by that award within its territories as if it were a final judgment of a court in that State." Convention on the Settlement of Investment Disputes between State and Nationals of Other States, opened for signature Aug. 27, 1965, art. 54(1), 17 U.S.T. 1270, at 1291, 575 U.N.T.S. 159, at 194.

The rise of international economic arbitration has been explained as the attempt by international business to develop "in appropriate cases, a jus gentium or a lex mercatoria of a new type, free of the contingencies and prejudices which dominate the scene in the various States." RENE DAvID, ARBITRATION IN INTERNATIONAL TRADE 3 (1985). "[W] hen parties request that arbitrators adjudicate their dispute in accordance with international law or with the general principles of law, their intention is to escape from the national systems of law." Id. at 350-51.

86. See, e.g., Jim Chen, Epiphytic Economics and the Politics of Place, 10 MinN. J. Global TRADE I, 4 (2001) (counseling "vigilance against protectionist wolves cloaked in wooly talk about 'national interests,' 'public order,' and 'precautionary prudence"').

87. See Globalization vs. Nature, supra note 18. The Turning Point Project's website and the series of ads in the New York Times may be viewed at http://www.turnpoint.org. For a disparaging view of the antiglobalization protestors, see Robert L. Bartley, Clinton Gives a Pass to Globaphobia, WALL ST. J., Jan. 31, 2000, at A44. In the words of then-Mexican President Emesto Zedillo:

A peculiar alliance has recently come into life. Forces from the extreme left, extreme right, environmentalist groups, trade unions of developed conntries and some self-appointed representatives of civil society are gathering around a common endeavor: to save the people of developing countries from development.... [They express] a very revealing common denominator: the word protection.

Id.

88. Invisible Government, N.Y. TIMEs, Nov. 29, 1999, at A15 (advertisement number three in a series for The Turning Point Project, http://www.turnpoint.org). The advertisement included: 
now-infamous Battle in Seattle, ${ }^{89}$ followed in succession by protests elsewhere ${ }^{90}$ the antiglobalization protestors managed to derail the opening of the WTO's rounds of trade talks and oppose its plans towards imcreased liberalization..$^{91}$ In language that is resoundingly nationalist, yet at the same time internationalist in tone, protestors, joined by a common concern for "global justice," complam about the loss of national sovereignty, the WTO and its "unprecedented powers...to rule on whether laws of nations-concerning public health, food safety, small business, labor standards, culture, human rights, or anything - are 'barriers to trade' by WTO standards." 93

The WTO is already among the most powerful, secretive, and undemocratic bodies on Earth. Its authority extends deeply into the internal political processes of sovereign countries, forcing them to alter laws and priorities. It is fast becoming a bonafide global government for the new millennium.... The central idea of the WTO is that free trade-actually the values and interests of global corporations-should supersede all other values.

Id.

89. For a critique of the antiglobalization critics, see Globalisation and Its Critics, supra note 48, at 3-30. For a critique of the antiglobalist position that globalization hurts poor workers in poor countries, see $i d$. at 10-13 \& 28-30. For a defense of the Seattle protests and mass resistance generally, see Balakrishnan Rajagopal, Taking Seattle Resistance Seriously, THE HINDu, Dec. 11, 1999, at 10, and Saadia Toor, Child Labor in Pakistan: Coming of Age in the New World Order, 575 AnNals 194 (2001).

90. David Montgomery, For Many Protesters, Bush Isn't Main Issue, Wash. Post, Jan. 20, 2001, at A14 (describimg protests against the IMF and World Bank in Washington D.C. and Prague, and against furthcr trade liberalization for the Americas in Quebec City); America Prepares Law and Politics, Boston Globe, Sept. 30, 2001, at A1 (cominenting on protests in Seattle in 1999, Pragne in 2000, Quebec City in the spring of 2001, and Genoa in the suminer of 2001); see also supra note 18.

91. Invisible Government, supra note 88. The advertisenent included:

[T]he Godzilla of WTO plans is to revive soine of the old, discredited Multilateral Agreement on Investment. Those rules would impose restrictions on every level of government; down to states, countries and cities. Foreign companies would have to be given "national treatment," Id.

i.e., treated exactly as if they were local companies.

92. America Prepares Law and Politics, supra note 90 (describing how Mobilization for Global Justice led antivar protests and denounced economic injustice as the "root causes" of terrorisin); R.C. Longworth, Rebels with Many Causcs, CHI. TRIB., Aug. 5, 2001, at C1 (describing the antiglobalization movement as a "call for global justice" uniting religious activists, students, environmentalists, labor, all opposed to "Washington Consensus" of free trade, privatization and free markets); Montgomery, supra note 90 (describing the "global justice" crowd of "save the rain forests" and antisweatshop activists, feminists, and human rights workers); Tom Morganthau, Getting Ready for "Seattle II," NEWSwEEK, Apr. 24, 2000, at 40 (describing the "Mobilization for Global Justice" as opposed to Third World debt, child labor, and environmental degradation).

93. Globalization vs. Nature, supra note 18. The antiglobal movement is not confined to the United States. Jose Bove, a Frenchman arrested on charges of vandalizing a McDonald's in August 1999, has been lauded in French newspapers for standing up to globalization, particularly American-led globalization, with his slogan “'McDo Dehors, Gardons le Roquefort!' (McDonald's Get Out, Let's Keep the Roquefort!)" Even President Jacques Chirac was prompted to declare "that he, too, detests McDonald's food." Suzanne Daley, French See a Hero in War on "McDomination," N.Y. Tmes, Oct. 12,1999 , at A1. Bove's opposition to U.S. imposition of high tariffs on Roquefort cheese and pate de foie gras in retaliation for the EU's decision to ban U.S. hormone-treated beef struck a nerve with the French, who view the issue in wider terms-the tyranny of the market versus "nostalgia for a way of life," local culture, and local tastes. Id. As Bove himself put it: "There have been three totalitarian 
While protestors rallied in the streets of Seattle and condemned multinational corporations for their exploitation of Third World workers, President Clinton delivered his indictment of child labor and his call to provide Third World children with a way "out of the soccer ball industry in Pakistan, out of the shoe industry in Brazil, the fireworks industry in Guatemala." 94 The movement that Seattle epitomizes, in other words, combines the typically nationalist denunciations of globalization ${ }^{95}$ with concomitant expressions of concerns for international matters beyond the national boundary. ${ }^{96}$

In these ways and through these dichotomies and polarities, nationalism and internationalism, and their particular subvariants, "as ideologies, as sets of mental attitudes,"97 have staked out their respective boundaries on market and state. The tensions and conflicts between the two have only increased in recent years as globalization- "probably the most contentious philosophical issue underlying the law of trade and development"98 today - is added to the mix of politics and sovereignty on the one hand, and markets and interdependence on the other.

forces in our life time ... The totalitarianism of fascism, of communism and now of capitalism. How can people try and tell us that we must import hormone-enhanced beef? What is that?" Id.

94. Roger Cohen, Clinton Remark on Child Labor Irks Brazil, N.Y. TIMES, Dec. 7, 1999, at A14. In response to President Clinton's remarks, Brazil noted, for example, that the shoe industry has made huge progress towards eliminating child labor, as U.N. studies have corroborated, and that the use of child labor is commonplace only in the coal business. "'But it so happens that Brazil does not export coal to the United States, or street children." Id. (quoting Klaus Kleber of Gazeta Mercantil, Brazil's leading business newspaper). According to Brazil, behind the apparent lofty concern of countries like the United States for workers' and children's rights in developing countries lies "down-to-earth political and economic considerations." Id.

95. "Under globalized free trade, countries as diverse as Sweden and India, Canada and Thailand, Bolivia and Russia are meant to merge their economies, and homogenize their values toward maximum commodity accumulation. This puts the whole planet in a single giant economic (and political) structure, with global corporations in charge," so that "[o]lder values like preserving nature, or protecting workers, or public health, or communities, or democracy are viewed as impediments to global corporate growth." Globalization vs. Nature, supra note 18.

96. For a description of the protestors' position, see Mark Wcisbrot, Last Stop for Corporate Globalization: Seattle '99, available at http://www.zmag.org/CrisesCurEvts/Globalism/wtoweis.htm (last visited Jan. 31, 2002) (on file with author) (describing protestors' concern for "European consumers," "workers," and "the poor," in rich and poor countries, because free trade with Mexico has left workers in Mexico and the United States with lower real wages than those they had in the 1970s); see also America Prepares Law and Politics, supra note 90 (favoring the "'globalization of social justice, of human rights, of environmental protection"'); Montgomery, supra note 90 (denouncing globalization as "a war against the poor in the Third World, conducted by the corporate power structure in the U.S.," according to a codirector of the International Action Center).

97. Slaughter Burley, supra note 36 , at 585 .

98. Chen, supra note 86 , at 7. 


\section{II}

\section{THE INTERNATIONALIZATION OF THE MARKET}

\section{A. Globalization of Production}

At the heart of the globalization debate lies the market, or at least the ideology of the free market-the "global business civilization," in other words, and its relationship to the nation-state. Globalization marks the beginning of a new era in the relationship between modernity and the nation-state on thc one hand and postmodernity and the global age on the other. "Fundamentally the Global Age involves the supplanting of modernity with globality ...." ${ }^{\prime 100}$ Consequently, the nature of competition between and among states has changed from one of competing for territories to one of competing for markets, making trade and finance policies more significant than defense and foreign policies. ${ }^{101}$ For scholars writing about this globalist framework, markets and other nonstate entities are deemed to be the principal actors in the political and economic orders. ${ }^{102}$

For others who study globalization from an international franework, the emphasis is on the political variant of economic globalization. Although "[t]he nation-state has 'lost' sovereignty to regional and global institutions and to markets[, it] has also acquired new areas of control in order to promote "national competitiveness." 103 From this perspective, the

99. Susan Strange, The Name of the Game, in SEA-Changes: AMERICAN Foreign Policy In A World Transformed 238, 260 (Nicholas X. Rizopoulos ed., 1990) [hereinafter SEA-Changes]. This "global business civilization" consists of a "complex network or web of transnational, bilateral bargains-bargains between corporations and other corporations, between corporations and governments, and between governments." Susan Strange, Protectionism and World Politics, 39 INT'L Org. 233, 234 (1985); Cf. Boaventura de Sousa Santos, Toward a New Common Sense: Law, Science and Polrtics in the Paradigmatic Transition 261 (1995) (describing the links among economics, culture, and politics); H. W. Arthurs, Globalization of the Mind: Canadian Elites and the Restructuring of Legal Fields, 12 CAN. J. L. \& Soc'y 219 (1997) (describing “globalization of the mind" as equally as inportant as globalization of business).

100. Martin albrow, The Global Age 4 (1997); see also Roland Robertson, Globalization: Social Theory and Global Culture 113 (1992); Malcolm Waters, Globalization 1 (1995) ("[G]lobalization may be the concept of the 1990s, a key idea by which we understand the transition of human society into the third millennium.").

101. Susan Strange, The Defective State, DaEdalus, Spring 1995, at 55-74; see Sea-Changes, supra note 99, at 243 ("When states ... try to use their power to influence where and how international production takes place, they find they cannot direct, as with trade. They can only bargain.").

102. See generally Lowell Bryan \& Diana Farrell, Market Unbound: Unleashing Global Capitalism (1996); Susan Strange, The Retreat of the State (1996); Henry Wendt, Global Embrace: Corporate Challenges in a Transnational World (1993).

103. Vincent Cable, The Diminished Nation-State: A Study in the Loss of Economic Power, DAEDAlus, Spring 1995, at 23-24; see also Meinhard Hilf, Settlement of Disputes in International Economic Organizations: Comparative Analysis and Proposals for Strengthening the GATT Dispute Setlement Procedures, in The New GatT Round of Multilateral TRade Negotiations: Legal AND Economic Problems 285, 321 (Ernst-Ulrich Petersmann \& Meinhard Hilf eds., 2d updated ed. 1991) (commenting that "[i]nternational economie integration, influenced by a multitude of uncontrollable actors, entails a loss of sovereignty"). 
nation-state itself has not been diminished but has simply allowed itself to be internationalized, acting as mediator and negotiator with the global political economy and ensuring that the domestic economy can be effectively adjusted to the mandates of the world economy. ${ }^{104}$

From either globalist or internationalist orientation, commerce has transcended territorial definition and is now extraterritorial and global in orientation. ${ }^{105}$ Because "almost every factor of production-money, technology, factories, and equipment-moves effortlessly across borders. ...", 106 in time "[t]here will be no national products or technologies, no national corporations, no national industries. There will no longer be national economies, at least as we have come to understand that concept." 107 No longer are "national corporations," that is, corporations incorporated in or identified and associated with a certain nation-state, limited, either in their production or operation, to the territory of their own or any particular nation-state. ${ }^{108}$

104. See generally Robert W. Cox \& Timothy J. Sinclair, ApProaches to World ORDeR (1996). For a different version of this argument, see Anne Marie Slaughter et al., International Law and International Relations Theory: A New Generation of Interdisciplinary Scholarship, 92 AM. J. INT'L L. 367,378 (1998) (arguing that the state is no longer a unitary actor but a disaggregated entity, where distinct government institutions such as legislatures, executives, courts, and administrative agencies, act quasi-autonomously with their counterparts internationally).

105. This transformation from national to global parallels the earlier transformation in the American economy from regional to national. As technological developments affect transportation and communication and as global markets are further integrated, the need for an amended legal regime becomes more pressing. The American economy went through similar changes during the period from 1815 to 1860 , the period of major innovations in rail, canal transportation, and communication. See, e.g., George Rogers Taylor, The Transportation Revolution, i 8 i 5-1860 (1989); Richard B. Du Boff, Business Demand and the Development of the Telegraph in the United States, I844-1860, 54 Bus. HIST. REv. 459 (1980). Such changes facilitated the formation of an integrated national economy, as foreign, out-of-state corporations--no longer disadvantaged by physical distance-began expanding their businesses into states other than their home states, resulting in the erosion of local monopolies. Sidney Ratner et al., The Evolution of the American Economy: Growth, Welfare, and DECISION MAKING 123 (1979).

106. ReICH, supra note 80 , at 8 .

107. Id. at 3; see also GREIDER, supra note 20, at 44 ("What is a nation, after all, if commerce has destroyed the meaning of national boundaries? For that matter, what is a citizen?"). For opposing views that argue that corporate nationality still matters, see, for example, Paul Magnusson, Why Corporate Nationality Matters, Bus. WK. July 12, 1993, at 142, and D'Andrea Tyson, supra note 8, at 37.

108. American companies, for example, employ, at least according to a 1994 report, 5.4 million people abroad, with $80 \%$ in manufacturing. The issue is the loss of jobs and the question thus is "Why can't the goods and services that these foreign workers produce be supplied from the United States? Why must companies migrate abroad, shedding some of their national identity and loyalty?" Louis Uchitelle, U.S. Corporations Expanding Abroad at a Quicker Pace, N.Y. Times, July 25, 1994, at A1.

It should be noted that historically, there have been business enterprises with some degree of foreign presence since the Middle Ages. See PeTER T. MUChlinsKi, Multinational ENTERPRises AND THE LAW 19-20 (1995); Yitzhak Hadari, The Structure of the Private Multinational Enterprise, 71 Mich. L. Rev. 729, 735 (1973). For example, trading firms in ltaly had operations and branches in other European countries as early as the thirteenth century. $I d$. at 735 . Similarly, one could also consider some of the European colonial trading companies of the sixteenth and seventeenth century, such as the British East India Company, a multinational corporation. Nonetheless, most business 
This shift has meant more than simply the internationalization of economic activities. ${ }^{109}$ It has, rather, also resulted in a fundamental transformation in the relationship between market power and state authority, in which the state is increasingly unable or unwilling to regulate the activities of its internationally mobile corporate actors. ${ }^{110}$ This transformation provoked, in turn, a shift from public to private modes of regulation and a shift from tcrritorially based to nonterritorially based centers of authority. ${ }^{111}$ It was remarked, even as early as 1969 , that

[t]he international corporation has no country to which it feels more loyalty than any other, nor any country where it feels completely at home.... The nation-state is just about through as an economic unit .... The world is too small. It is too easy to get about. ${ }^{12}$

In more recent years, the global economy has inade it all the more easy for multinational companies ${ }^{113}$ to engage in transnational economic activities such as "world-wide sourcing"114 and foreigu direct investment," thus

historians mark the mid-nineteenth century as the point at which the multinational corporation as we currently know it first emerged. See MuchulNsKI, supra, at 19-20.

109. Some of the transformations associated with globalization were identified as early as 1944 by Karl Polanyi. See Karl Polanyi, The Great Transformation (1944). However, while the rise of the market and the retreat of the state might have occured previously, they did not occur with such speed or breadth. New York Times columnist Thomas Friedman observed:

[T]oday's era of globalization is not only different in degree; in some very important ways it is also different in kind.... Today's era of globalization is built around falling telecommunications costs-thanks to microchips, satellites, fiber optics and the Internet.

These new technologies are able to weave the world together even tighter.

FRIEDMAN, supra note 10 , at XV.

110. See generally U.N. Conference on Trade \& Dev., Programme on Transnational Corps., World Investment Report 1993: Transnational Corporations and Integrated InTERnational Production, at 161, U.N. Doc. ST/CTC/156, U.N. Sales No. E.93.II.A.14 (1993) [hereinafter WIR 1993] (describing inability of states to regulate corporate multinational activities whether for tax and other revenue-raising purposes or to restram unfair business practices).

111. In this way, free market globalization, like its antithesis from a prior era (communist internationalism), is obtuse to the pull of the particular and instead exhibits behavior that generally scorns the relevance of place. See, e.g., The National Question, Selected Writings By Rosa LUXEMBURG 135, 159, 161 (Horace B. Davis ed., 1976) (favoring imternationalism over nationalism, which Luxemburg considered to be a mask for class division); see also JoHN GRAY, FaLSE Dawn: The Delusions of Global Capitalism 3 (1998) (equating the flaws of global capitalism with those of global communism).

112. C.P. Kindleberger, AMERICAN Business Abroad 207 (1969).

113. The term "multinational corporation" was comed in 1960 by David E. Lilienthal, who was then the Director of the Atomic Energy Commission. See Paul A. Baran \& Paul M. Sweezy, Monopoly Capital 192 (1966); see also D. K. Fieldhouse, The Multinational: A Critique of a Concept, in Multinational Enterprise in Historicar Perspective 9 (Alice Teichova ed., 1986).

114. Susan Strange, States and Markets 82 (2d ed. 1994); see also Norman Jonas, The Hollow Corporation, Bus. WK., Mar. 3, 1986, at 57, 58. Jonas wrote:

Outsourcing breaks down manufacturers' traditional vertical structure, in which they make virtually all critical parts, and replaces it with networks of small suppliers.... In the short run, the new system may be amazingly flexible and efficient. In the long run, however, some experts fear that such fragmented manufacturing operations will merely hasten the hollowing [out of U.S. industry]. 
freeing companies from the restraints and "factor endowment of a single nation" 116 and allowing them access to resources and markets across national boundaries. ${ }^{117}$

Firms have pursued internationalization in two ways, by engaging in "glocalization" or "globalization." Firms may "glocalize," diversifying internationally as a business strategy, primarily to avoid "being treated as an 'outsider,' or being hit by trade or investment barriers and thus losing market share ...."118 "Glocalizing" firms are deemed multinationals, that is, more international than global. While they do decentralize production and sales by extending their operations internationally, their decisionmaking apparatus remains home-centered, with the more high-value-added

Id. Various industries are resorting increasingly to outsourcing. See, e.g., J. Linn Allen, Chicago Mecca for Real Estate Gurus, CHI. TRIB., Sept. 3, 1996, at 1 (describing how a major telecommunications company outsources management of its real estate assets to another company); Leslie Helm, The Fading Metropolis, L.A. TIMES, June 3, 1996, at D1 (describing how a major accounting firm institutes "hoteling" for its auditors; auditors are to make reservations to use a limited number of office spaces when not conducting audits); see also infra note 140.

115. In the United States, foreign direct investment is defined as "the ownership or control, directly or indirectly, by one foreign person of 10 per centum or more of the voting securities of an incorporated U.S. business enterprise or an equivalent interest in an unincorporated U.S. busincss enterprise, including a branch." 15 C.F.R. $\$$ 806.15(a) (2001). “'A key element of the structural transformation into the global company town was the role played by the multinational corporation and foreign direct investment... Technological advances have played a part in triggering the global revolution, but the multinational corporation has evolved to become an important vehicle for allocating resources." Gordon R. Walker \& Mark A. Fox, Globalization: An Analytical Framework, 3 IND. J. GLOBAL LEGAL STUD. 375, 387 (1996) (quoting Bijit Bora, The Implications of Globalisation for Australian Foreign Investment Policy, in ECONOMIC PLANNING ADVISORY COMMISSION, GLOBALIZATION: Issues For Australia 92 (1995).

The flow of foreign direct investment into and out of a country is routinely used as a reliable indicator or gauge of corporate international expansion. See U.N. Center on Transnational Corporations, The Process of Transnationalization in the 1980s, in READINGS IN INTERNATIONAL Business: A Decision Approach 23, 26, 33 (Robert Z. Aliber \& Reid W. Click eds., 1993). The growth of foreign direct investment in 1995 exceeded that of export of goods by $18 \%$ and world output by $2.4 \%$. U.N. CONFERENCE ON TRADE \& DEV., WorLd INVESTMENT REPORT 1996: INVESTMENT, Trade and International Policy ARRangements at 3, U.N. Sales No. E.96.1I.A.14 (1996) [hereinafter WIR 1996]. At one point, almost half of the total world stock of foreign direct investment could be traced to one single country, the United States. MUCHLINSKI, supra note 108, at 26-27. But as European and Japanese corporations began to expand internationally, by 1985, the United States accounted for only $25 \%$ of the world's total foreign direct investment share, with Western Europe as a region accounting for almost $50 \%$ and Japan for $11 \%$. Id. at 28 .

116. Michael E. Porter, The Competitive Advantage of Nations 14 (2d ed. 1998).

117. Asea Brown Boveri, Inc., a Swiss-Swedish electrical engineering company, considers itself "a coinpany without any regard to national boundaries," for example. Charlene Marmer Solomon, Transplanting Corporate Cultures Globally, PERsonNel J., Oct. 1993, at 78, 80 (statement by Richard P. Randazzo, ABB's vice-president of Human Resources). $\mathrm{ABB}$ also plauned to lay off a thousand Swiss workers and invest $\$ 1$ billion in Asia. GREIDER, supra note 20, at 62 .

118. WiNFRIED RUIGROK \& ROB VAN TULDER, THE LOGIC OF INTERNATIONAL RESTRUCTURING 179 (1995). For example, the growth of regional trading blocs, such as the European free trade region, was one of the key factors that caused U.S. and Japanese firms to establish subsidiaries in European member countries for fear of being excluded from "Fortress Europe." U.S. INT'L TRADE COMmission, The EFFects of GREater ECONOMIC INTEgRation Wrthin the EuRopean CoMmunity on the UNITED STATES (USITC Pub. No. 2204 (July 1989)). 
component of production, such as research and development, to be retained at home. ${ }^{119}$

By contrast, globalizing firms, transnationals in the true sense of the word, are "[t]ransnational in operation, ownership, and often in origins." Transnationals "exceed national boundaries, transcend definitions of national identity, and regard the entire globe as a single theater of operations."121 Transnationals are more likely to adopt a functional and decentralization approach to decision making so that if research and development is allocated to a particular unit of the firm, then that unit bears responsibility within the company for all research and developinent. ${ }^{122}$

The debate as to whether or not corporations are multinational or transnational, glocalizing or globalizing, regional or global in orientation, does not significantly change my central point: ${ }^{123}$ corporations are adopting production and investment strategies that result in linkages across national

119. RuigroK \& VAN TUlder, supra note 118, at 9-10; Louis W. Pauly \& Simon Reich, National Structures and Multinational Corporate Behavior: Enduring Differences in the Age of Globalization, 51 INT'L ORG. 1, I-30 (1997). Others define multinational corporations more generally, as affiliated corporations incorporated in different jurisdictions but under common control conducting a common enterprise. See generally Phillip I. Blumberg, The Multinational Challenge to Corporation Law: The Search For a New Corporate Personality (1993); WIR 1993, supra note 110, at 18391.

120. WENDT, supra note 102, at 3. Others disagree about the extent to which a firm is truly global. See, e.g., William R. Miller, The Role of Global Corporations, in Global CoRporations and NatTon-STATEs: Do Companies or Countries Compete? 21 (Richard S. Belous \& Kelly L. McClenahan eds., 1991); Ethan B. Kapstem, We Are US, NAT'L INT., Winter 1991-92, at 55-62; Robert Kuttner, One Big, Happy Global Economy? Not Yet, Friend, Bus. Wk., Oct. 15, 1990.

121. WendT, supra note 102, at 5. For example, Asea Brown Boveri, a Swedish company formed through a merger between Asea, a Swedish engineering company, and Brown Boveri, a Swiss company, has $85 \%$ of its sales and $50 \%$ of its shares held outside of Sweden. William J. Holstein, The Stateless Corporation, Bus. Wk., May 14, 1990, at 98, 103. The company's official language is English, although it is the mother tongue of only one third of its approximately 18,000 employees located in forty different countries; members of the company's coordinating executive committee come from eight countries; and its approximately 500 global managers routinely alternate among various foreign assignments. The ABB of Management, THE EcoNomst, Jan. 6, 1996, at 56.

122. Holstein, supra note 121 , at 98 . Such a fully globalizing strategy might be contingent on the fact that markets are truly global and consumer tastes truly standardized so that there is little need for customization. RUIGROK \& VAN TULDER, supra note 118, at 180-82. Coca Cola, McDonald's, and Levi Jeans are examples of firms whose products reflect umiversal tastes. Other transnationals, especially those from sinaller markets, such as the Netherlands, Sweden, and Switzerland, have adopted global strategies as well. Those often cited include Shell, Umilever, Volvo-Renault, Asea Brown Boveri, Arjo Wiggius Appleton, Sony, IBM, and Nestle. WeNDT, supra note 102, at 12; see also The Discreet Charm of the Multicultural Multinational, THE ECONOMIST, July 30, 1994, at 58 [hereinafter Discreet Charm] (discussing how McDonald's issues its employees worldwide operation manuals and how Umilever brings managers from around the world to its training headquarters in the United Kingdom); The World Turned Upside Down, THE Economist, June 24, 1995, at S5.

123. To the extent that glocalizing firms may exhibit less economic commitment to the particular national community in which they operate, that may be a significant factor in the state's determination of corporate nationality and consequently, the state's relationship with the firms at issue. See infra Part III. 
borders. The internationalization of economic activities have produced at least three identifiable and significant changes in the economic landscape.

First, it is likely that a product produced by a multinational corporation can no longer be unambiguously identified as the product of a particular state; equally likely, its components parts have been internationally sourced and produced. "During earlier years when the norm was to produce goods in one country and export from there, the use of origin rules to define a product's place of manufacture was simple. Over the past decade the issue has become more complicated." ${ }^{24}$ A Pontiac Le Mans, ostensibly a General Motors product of American nationality, is in fact a globally composite product involving South Korean assembly; Japanese engines, transaxles and electronics; German design and style engineering; Taiwanese, Singaporean, and Japanese small components; British advertising and marketing; and Irish and Barbadian data processing. ${ }^{125}$ To underline the multinational composition of its product, Toray, Japan's largest synthetic-fiber manufacturer, has adopted the label "Made in Toray."126 This internationalization of a product's "origin" has profound implications for an international and national trade regime still very much based on the

124. E. Ivan Kingston, The Economics of Rules of Origin, in RULES OF ORIGIN IN INTERNATIONAL TRADE 9 (Edwin Vermulst et al. eds., 1994). Consider the following examples. An official of the Caterpillar Tractor Corporation noted that

while we export from the U.S., our views as to transportation, markets, and product are worldwide. For example, there is no U.S.-made Caterpillar tractor. A Caterpillar productwherever it is built-is just that-a Caterpillar product-graphic evidence that people of different national origins and political interest can achieve common objectives.

David H. Blake \& Robert S. Walters, The Politics of Global Economic Relations 112-13 (4th ed. 1992). Similarly, precision ice hockey equipment may be "designed in Sweden, financed in Canada, and assembled in Cleveland and Denmark for distribution in North America and Europe, respectively, out of alloys whose molecular structure was researched and patented in Delaware and fabricated in Japan." REICH, supra note 80, at 112. Products can no longer be presumed to be made in one or even two countries-hence the following label affixed on a computer part: "This part was made in Malaysia, Singapore, the Philippines, China, Mexico, Germany, the U.S., Thailand, Canada and Japan. It was made in so many different places that we cannot specify a country of origin." FrIEDMAN, supra note 10 , at 33.

125. REICH, supra note 80 , at 113 . The confusion associated with product nationality is by now routine, especially in automobile manufacturing. The Chevy may be built in Mexico from imported parts and then reimported into the United States; a Ford built in German plants by Turkish workers and sold in Hong Kong and Nigeria; a Toyota designed by an American designer at Toyota's Newport Beach, California, Calty Design Research Center, assembled at the Georgetown, Kentucky plant from American-made parts (except that the engine and drive trains are still Japanese) and then test driven at Toyota's Arizona proving ground. BARBER, supra note 1, at 24, 315 n.7. The 1977 first-generation Honda Accord made in Marysville, Ohio, originally had no American parts. The 1982 model contained $50 \%$ American parts and the new fifth-generation Accord $80 \%$. See Doron P. Levin, Honda's Star Gets Another Sequel, N.Y. Times, Aug. 27, 1993, at D1.

Other industries have gone through similar experiences. McDonnell Douglas, for example, engaged its global partners in the construction of its MD-95 planes, with Halla Engineering of South Korea building the wings, BMW/Rolls-Royce developing the engines, and Alenia of Italy building the fuselage. Stanley Holmes, When Jobs Go South, Seatrle Times, Nov. 12, 1995, at A1.

126. Andrew Pollack, Breaking out of Japan's Orbit, N.Y. Times, Jan. 30, 1996, at DI. 
presumption that products, like corporations, have distinct and identifiable countries of origin. ${ }^{127}$

Second, this confounding combination of product cross-nationalities is matched by a similarly confounding parallel cross-ownership among the corporations. The national corporations that were once clearly identified with their countries of origin are now international, or global, in orientation and ownership. ${ }^{128}$ Equally significant, corporate players are more likely to engage in "genuinely strategic alliances"129 of "low or non-equity ventures that mix and match corporate strengths in research, development, manufacturing, marketing, service, and other business functions"130 than im "establishing dominance in all of [a] business system's critical areas,"131 allowing them to spread the costs and risks of product development and

127. For a discussion of the policies underlying rules of origin, see RuLEs of ORIGIN IN INTERNATIONAL TRADE, supra note 124.

128. Daimler-Benz AG, a German industrial champion, and Chrysler Corp., the American maker of Jeeps, merged in a culture "where shared values of open markets, hard noney and standardized technology increasingly take precedence over old-fashioned nationalism." Joseph B. White, Global Mall, Wall ST. J., May 7, 1998, at Al ("More and more, national boundaries, cultural variations and accidents of geography such as the Atlantic Ocean aren't stopping business leaders who see a chance to expand their reach as trade barriers fall, communication becomes cheap and consumer tastes for everything from cola to cellular phones converge."). Anheuser-Busch owns a stake in Japan's biggest brewery, Kirin, as well as a 5\% share of China's Tsingtao and a 10\% share of Antarctica, Brazil's leading beer company (as of 1997). GREIDER, supra note 20, at 20. In the past ten years, the growth of worldwide cross-border mergers and acquisitions has approximated the growth of foreign direct investment flows. WIR 1996, supra note 115, at 7. In 1995, the total value of cross-border mergers and acquisitions was $\$ 229$ billion, twice the value of the 1988 level. Id. at 10.

129. Kenichi Ohmae, The Global Logic of Strategic Alliances, HARv. Bus. Rev., Mar.-Apr. 1989, at 143 (discussing alliances forged among corporations for distribution purposes and for research and development in industries ranging from automobile to pharmaceutical). This phenomenon is also referred to as international strategic alliances, see U.N. Center on Transnational Corporations, supra note 115 , at 27 , where separate entities engage in various collaborative agreements for marketing, joint ventures, subcontracting, cross-licensing, research and development, technology exchanges, and so forth. See Bernard Michael Gilroy, Networking in Multinational Enterprises 34 (1993); see also What Is a U.S. Company?: Hearing Before the Subcomm. on Sci., Research \& Tech. and the Subcomm. on Int'l Scientific Cooperation of the Comm. on Science, Space, and Tech., 101st Cong. 30 (1989) (describing "cross-border alliances between companies from different countries that blur the national identity of products, processes and individual enterprises"), 34 (describing how "[d]etermining the nationality of corporate ownership requires sorting through this interwoven network of transnational alliances"), 66 (explaining that because of costs, technology, and marketing reasons, companies have had to enter into alliances, as "no single company can afford the cost of staying on the leading edge") (statements of Dr. John Kline, Deputy Director, Langegger Program, Georgetown University) [hereinafter What Is a U.S. Company Hearings].

In the 1980s, U.S. firms entered into an estinated 2,000 strategic alliances with European firms. GilRoY, supra, at 26 (1993). Germany's Siemens has forged a partnership with Skoda Plzen to produce steam turbines in the Czech Republic; Japan's NEC collaborated with Korea's Samsung to make DRAM memory chips; AT\&T formed various alliances with the telephone companies of Sweden, Switzerland, and the Netherlands, and MCI with British Telecommunications. GRemER, supra note 20, at $20-21$.

130. What Is a U.S. Company Hearings, supra note 129, at 33 (statement of Dr. John Kline).

131. Ohnae, supra note 129 , at 143. 
providing each firm with access to new technology that is not yet available within the firm. ${ }^{132}$

Third, and perhaps most significant, the internationalization of economic activities has coincided with the transition from high-volume production such as manufacturing to high-value production such as information technology, ${ }^{133}$ resulting in an even more accelerated transformation of the multinational corporation-from one territorially bound to one more decentralized and hence less connected to its country of nationality. ${ }^{134}$ Consequently, high-volume production of standardized commodities requiring heavy investment in immobile assets has been supplanted by high-value production of nonroutine, specially tailored products and services requiring neither fixed machinery nor factory. ${ }^{135}$ For example, in

132. John M. Kline, The Inverse Relationship Between Nation-States and Global Corporations, in Global Corporations and Nation-STates: Do Companies or Countries Compete?, supra note 120 , at 2 .

133. See generally U.S. Congress, Office of Technology Assessment, Electronic ENTERPRISES: LOOKING TO THE FuTURE 13-15 (1994); Peter F. Drucker, Management and the World's Work, HARV. Bus. REv., Sept.-Oct. 1988, at 65 (relating the decline of manufacturing and the rise of information industry in the United States); Siew Meng Leong \& Chin Tiong Tan, Managing Across Borders, 24 J. INT'L Bus. STUdiES 449, 449 (describing shift in "volune to value production").

The essential difference of the new information technology-its capacity to anplify human intellect rather than muscle-is integral to the social and economic consequences that are unfolding.... [D]ecision-making can be decentralized in reformed workplaces and production jobs can be scattered across many distance places, even at a computer terminal in one's home.

GREIDER, supra note 20, at 28; see also BARBER, supra note 1, at 59-87. Indeed, the information technology industry is widely acknowledged to be the new coin of the realm in international trade. See, e.g., Laura D'Andrea Tyson, Who's Bashing Whom?: Trade Conflicts in High-Technology INDUSTRIES 11-13 (1993).

134. Corporations are eager to present an "anational," or cosinopolitan, face. Reebok's advertising caunpaign promoted the company under the banner "On Planet Reebok." BARBER, supra note 1, at 24. Ralph Lauren's perfume for men, Safari, promoted the concept of "Living Without Boundaries" in its 1992 launch campaign. Id. Toshiba proclaimed in its 1992 annual report that "as good corporate citizens' they 'do our part to ensure that progress continues within the world community." Id. In 1997, British Airways removed the Union Jack emblem from the tails of its planes and replaced the British flag with various ethnic designs because "the airline was no longer a British company with global operations, but a global company that happened to be headquartered in Britain." Undoing Britain?, THE ECONOMIST, Nov. 6-12, 1999, at 3. According to its chief executive, Bob Ayling, "'We are proud to have been born and raised in Britain ... [b]ut we want to show Britain as modem, not imperial." Id.

135. During the Industrial Revolution, wealth was created through the mobilization of technology combined with the accumulation of capital and the abundance of unskilled labor, see 9 THE NEW CAMBridge Modern History 31-47 (C.W. Crowley ed., 1965), for the mass production of industrial and consumer goods. 6 CAMBRIDGe EconomisT History of EUROPE 451-54 (M. M. Postan \& H.J. Habakkuk eds., 1966). To maximize profits, management focused on decreasing costs and producing ever larger quantities of products, by adopting various corporate growth strategies, such as forming trusts in the industrial and commercial sectors, Jeremy Atack \& Peter Passell, A New Economic VIEW OF AMERICAN HISTORY 474-81, 481-88 (2d ed. 1994), leading to "the dramatic wave of consolidations that took place around the turn of the century ...." Id. at 488. After World War $\Pi$, many of the largest manufacturing firms, particularly the American ones, were transformed from national to multinational enterprises through the development of subsidiaries and affiliates outside the home country, contributing thus to the increasing integration of one national economy with another. See 
terms of structure, the early multinational corporations in the manufacturing sectors operated on a clear division between the function of the company's headquarters versus its overseas operation. The company's headquarters in its home territory performed research and development, designing, and major production operations; the company's overseas activities were generally confined to assembly, distribution, sales, and marketing. ${ }^{136}$ Starting in the 1970 s, foreign affiliates and subsidiaries of multinationals assumed greater responsibility in a wide array of functions, such as research and development, product innovation, design, as well as production. ${ }^{137}$ Firms with worldwide, global strategies are now likely to favor greater integration of the parent and its subsidiaries and the adoption of global product standards, production processes, and organizational structures. ${ }^{138}$

With intellectual property as the new currency, the corporation is increasingly composed of decentralized corporate webs consisting of globally dispersed, mobile independent or semi-independent entities, each engaged in various forms of partnerships, joint ventures, subcontracting, cross-licensing, and brokering relationships with each other. ${ }^{139}$ In the

Raymond Vemon, Multinationals Are Mushrooming, in INTERNATIONAL EConomics AND International Economic Policy: A Reader 220, 220-21 (Philip King ed., 3d ed. 2000).

The earlier multinational corporations, however, were more likely to be involved in the extraction and production of natural resources or in the manufacturing of agricultural commodities. See MUCHLINSKI, supra note 108, at 22. After World War II, corporate investments internationally shifted toward technologically advanced manufacturing and services in other economically developed countries. Id. at 28 . Strategic resource was capital in the industrial age. In the current postindustrial age, strategic resource is knowledge. See generally Thomas A. Stewart, Brainpower, ForTunE, June 3, 1991, at 44; JoHn NaISBITT, Megatrends 17 (1982) ("Knowledge has already become the primary industry, the industry that supplies the economy the essential and central resources of production.").

136. Typically a company's first venture abroad begins with the exporting of products to foreign markets, followed by the establishment of distribution and assembly operations. At the next stage of involvement, the foreign operation engages in manufacture, sale, distribution, and servicing of products sold in the foreign country, and may eventually assume responsibility for research and developinent. See Hadari, supra note 108, at 746 \& n.91; Bohdan Hawrylyshyn, The Internationalization of Firms, 5 J. WORLD TRADE L. 72, 81 (1971).

137. See Louis Uchitelle, U.S. Businesses Loosen Link to Mother Country, N.Y. TIMES, May 21, 1989, at A1; see also Raymond Vernon, Transnational Corporations: Where Are They Coming From, Where Are They Headed?, in 1 TRANSNAT'L CoRPs. 7, at 10, 12 (1992); Hadari, supra note 108, at 746; Hawrylyshyn, supra note 136, at 81; Holstem, supra note 121, at 98 .

138. See Discreet Charm, supra note 122, at 57-58; Holstein, supra note 121, at 104. For example, in 1995, the Ford Motor Company, a U.S.-origin company, began impleinentation of a new reorganization and consolidation policy aimed at integrating its regional operations into a single global enterprise. See The World That Changed the Machine, The Economist, Mar. 30, 1996, at 63. Xerox, Caterpillar, IBM, Unilever, Siemens, and Hoechst, like Ford, also began to integrate their operations into global units. Discreet Charm, supra note 122, at 58.

139. John W. Kensinger \& John D. Martin, Financing Network Organizations, in THE NEW Corporate Finance 561 (Donald H. Chew, Jr. ed., 1993); Reich, supra note 80, at 92-93 (describing the proliferation of decentralized corporate webs: spin-off partnerships (independent businesses partially owned by headquarters after the spin-offs); spin-in partnerships (independent businesses spiuning into partnerships with headquarters); licensing; and brokering); Russell Johnston \& Paul Lawrence, Beyond Vertical Integration-The Rise of the Value-Adding Partnership, HARv. Bus. REv., 
knowledge-based economy, emphasis is on alacrity and flexibility. Companies in the highly competitive high-technology sectors must launch new products in multiple world markets-hence the rush to internationalize corporate operations. ${ }^{140}$

These shifts in corporate outsourcing, international alliances and ownership, and structural organization have prompted many commentators to note the emergence of the truly global corporation. ${ }^{141}$ The effects of this phenomenon on First World and Third World economic relations and on the international trade system are the focus of Part 11.B and Part 1I.C below.

July-Aug. 1988, at 94 (describing smaller value-added partnerships); Spinning It Out at Thermo Electron, THE ECONOMIST, Apr. 12, 1997, at 57 (describing spin-outs or spin-offs spun from larger companies such as Thermo Electron, which retains a majority stake in each spin-out but allows its spinouts more freedom than what conventional subsidiaries would normally be given); Jerry Useem, The Start-Up Factory, INC., Feb. 1997, at 40, 42, 46 (describing technology marketing partnerships such as Idealab, which is in the business of creating businesses by nurturing start-up companies through a network of "interdependent yet nominally independent companies, all built around a core base of knowledge."); John W. Wilson \& Judith H. Dobrzynski, And Now, the Post-Industrial Corporation, Bus. WK., Mar. 3, 1986, at 64; see also Friedman, supra note 10, at xv-xvi (describing how new technologies "allow companies to locate different parts of their production, research and marketing in different countries, but still tie them together through computers and teleconferencing as though they were in one place"); Gary Gereffi, Commodity Chains and Regional Divisions of Labor in Asia, $12 \mathrm{~J}$. ASIAN Bus. 75, 81-82 (1996) (describing the proliferation of the producer-driven and buyer-driven global commodity chain, with its many-tiered production networks).

140. U.S. Congress, Office of Technology Assessment, Multinationals and the National Interest: Playing by Different Rules 38 (1993) [hereinafter Multinationals and THE National INTEREST]. For a discussion of a product's "life cycle" and its relationship to foreign direct investment, see generally David K. EIteman ET al., Multinational Business Finance 47072 (6th ed. 1992).

Additionally, the accelerating life cycle, from conception to obsolescence, of new electronics products has made it too costly for even large companies such as IBM or Philips Electronics to invest globally in the production of new products. Jonathan Friedland \& Gary McWilliams, How a Need for Speed Turned Guadalajara into a High-Tech Hub, Wall St. J., Mar. 2, 2000, at A1. As a result, contract manufacturing is expected to grow $20 \%$ annually ovcr the next few years, from $\$ 60$ billion in 1998 to $\$ 149.2$ billion in 2003. Id. With speed (and not just cheap labor) becoming a crucial factor in the production process, places like Guadalajara, Mexico, have developed into high-tech hubs and principal manufacturing centers for electronics products sold in the United States. Companies like Cisco Systems switched to contract manufacturers to build their networking gear and other products. Id. The technology revolution has thus reinforced the trend towards worldwide outsourcing, see supra notes $133-40$ and accompanying text, as companies increasingly shed their previous organizational model of vertical integration to pursue a strategy of "buying parts or whole products from other producers, both at home and abroad." Jonas, supra note 114, at 58. Relying on their webs of alliances, toy companies such as Lewis Galoob Toys, with a mere 115 employees, were able to ensure that new products are on the shelves in U.S. stores quickly and efficiently. Lewis Galoob Toys relies on independent inventors for new designs and on independent partner contractors in Hong Kong who subcontract the labor-intensive manufacturing to factories in China. See Wilson \& Dobrzynski, supra note 139 , at 64 .

141. See Kenichi Ohmae, The Borderless World 114-36 (1990); Holstein, supra note 121, at 97; Reich, supra note 8, at 53; Cf. D'Andrea Tyson, supra note 8, at 37; Kapstein, supra note 120, at 55-62 (arguing that global corporations have not yet shed their national identities); Robert Kuttner, One Big, Happy Global Economy? Not Yet. Friend, Bus. WK., Oct. 15, 1990; see generally John H. Dunning, The Global Economy, Domestic Governance, Strategies and Transnational Corporations: Interactions and Policy Implications, TrANSNA T'L CORPS., Dec. 1992, at 11. 


\section{B. The Distributional Impact: Rich and Poor, High-Volume, High-Value}

International capital is footloose and, under the right economic conditions, may be enticed into or away from any country. While place-based communities that attract capital may have problems coping with the infusion of capital in the local economy, ${ }^{142}$ place-based communities abandoned by capital are faced with a far more serious problem. ${ }^{143}$ In the early 1990s, while capital flowed into the emerging markets of historically lesser-developed nations and "while the advanced economies remained stagnant or mired in recession, a league of poorer economies was enjoying a spectacular investment boom." "144 There is no doubt that the vast majority of countries in the world are still mired in "abject and dehumanizing poverty." 145 But for a number of developing countries that have successfully engaged the global economy, "[t]he new fulcrum is the shifting of opportunities for wealth and incomes from the older, richer societies to the poorer ones." 146

This new opening has created real opportunities for poorer countries to benefit from global economic activities, not through a U.N.-declared redistribution that calls for a new international economic $\operatorname{order}^{\mathrm{i} 47}$ or a "right to development," 148 but through a "market-based" frainework pursuant to economic integration, interdependence, and convergence. ${ }^{149}$ As one

142. See, e.g., Enrique R. Carrasco \& Randall Thomas, Encouraging Relational Investment and Controlling Portfolio Investment in Developing Countries in the Aftermath of the Mexican Financial Crisis, 34 Colum. J. Transnat'L L. 539 (1996).

143. See, e.g., Fran Ansley, Standing Rusty and Rolling Empty: Law, Poverty, and America's Eroding Industrial Base, 81 Geo. L.J. 1757, 1759 (1993).

144. GREIDER, supra note 20, at 22.

145. Report of the Secretary-General to the Prep. Comm. for the High-Level International Intergovernmental Event on Financing for Development 2, U.N. GAOR, 2d Sess., at 2, U.N. Doc. A/AC.257/12 (2000). The World Bank estimated that the percentage of the world's population still living in extreme and absolute poverty, defined as living on less than $\$ 1$ a day, fell from 28.3 to $24.0 \%$ between 1987 and 1998. See The World BANK, Global Economic Prospects and The Developing COUNTRIES 29 (2000); THE WORLD BANK GROuP, 200I POVERTY UPDate, at http://www.worldbank.org/html/extdr/pb/pbpoverty.htm (last visited Nov. 5, 2001).

146. GREIDER, supra note 20 , at 42 . These governments vie to have corporations contribute to the manufacturing and capital base, as well as the research and technology capabilities of their local firms and local economies. MUlTiNATIONALS AND THE NATIONAL INTEREST, supra note 140, at 2-3. "[T] he fact that people in rich countries now fret about developing countries' success, not their poverty, is itself a remarkable tribute to those countries' economic reforms." War of the Worlds, THE ECONOMIST, Oct. 1, 1994, at 5 .

147. Declaration on the Establishment of a New International Economic Order, G.A. Res. 3201, U.N. GAOR, 6th Spec. Sess., Supp. No. 1, at 3, U.N. Doc. A/9559 (1974).

148. Declaration on the Right to Development, G.A. Res. 41/128, U.N. GAOR, 41st Sess., Supp. No. 53, at 186, U.N. Doc. A/41/53 (1986).

149. See L. Alan Winters, Trade and Poverty: Is There a Connection?, in WTO Social STudies No. 5: TRAde, Income Disparity and Poverty 43, 43 (World Trade Org. ed., 2000), available at http://www.wto.org/english/news_e/pres00_e/prl81_e.htm (June 13, 2000); see also Harold J. Berman, 
writer has aptly noted:

[f]or the first time in human history, ... a fateful connection is emerging between the first [the rich countries at the top of the ladder] and the last. One end of the ladder (or seesaw) cannot defend its own general prosperity without attending to human conditions at the other end. For masses of people in the global marketplace, economic self-interest is converging with altruism. ${ }^{150}$

In other words, by taking advantage of this new opening provided by the internationalization of trade and investment, poor countries could leverage themselves out of poverty. Even Japanese corporations, traditionally more territorially tied to Japan than other corporations are tied to their home territories, have moved their operations, and consequently jobs, abroad. ${ }^{151}$ Approximately $50 \%$ of Sony's employees come from outside of Japan. ${ }^{152}$ By the early 1990s, Toyota's international production, that is, production outside Japan, was up to $20 \%$ of its total production. ${ }^{153}$ Mabuchi Motors, which has half of the world market for minuscule motors used to power toothbrushes, zoom lenses, and car windows, employs thirty-three thousand workers-one thousand in Japan, but most in cheaper labor markets elsewhere. $^{154}$

According to a controversial study, conventional economic analysis had underestimated the job losses suffered by advanced economies and gained by developing countries-shifts attributable to international trade in particular. ${ }^{155}$ Comparative advantage for a growing number of developing

The Role of International Law in the Twenty-First Century, 18 FordHAM INT'L L.J. 1617, 1621 (1995). Berman commented:

That humankind, in the aftermath of two world wars, has reached a turning point in its history, that the world has entered a new era of global interdependence, that all inhabitants of Planet Earth share a common destiny, is a historical fact, a political fact, an economic fact, a sociological fact, that has finally penetrated the consciousness of most of the earth's inhabitants.

Id.

150. GREIDER, supra note 20 , at 43 .

151. See Brenton R. Schlender, Japan Hits the Wall, ForTuNE, Nov. 1, 1993, at 128. Beginning in the 1990 s, with the appreciation of the yen, Japanese companies had to offset the proportionate rise in the price of Japanese goods in the export markets by shifting production to other nations in Asia. Sony's Walkman, for example, is now made entirely in Korea, Malaysia, and Indonesia. Greider, supra note 20 , at 69.

152. GREIDER, supra note 20, at 15 .

153. Andrew Pollack, Honda Set to Increase U.S. Output, N.Y. Times, Sept. 20, 1993, at DI.

154. Andrew Pollack, Today's Corporate Game Plans Know No Boundaries: Mabuchi Motors; an Un-Japanese Model for Japan, N.Y. Times, Jan. 3, 1994, at C1.

155. See generally Adrian WoOd, North-South TRADE, EMPLOYMENT aND 1Nequality: Changing Fortunes in a SkILl-Driven World (1994). This study has generated discussion because of the author's conclusion that international trade has increased trade between developed and developing countries, which has created adverse consequences, in terms of wage and job security, for lesser-skilled workers in rich countries. Economists who question the study believe, instead, that competition from low-wage producers in poor countries cannot be the primary cause of job losses of industrial workers in rich countries. For these economists critical of Wood's study, the technology revolution, not trade with poor countries, is the more important cause of job losses in rich 
countries no longer means just exporting raw materials or "low-tech, labour-intensive goods while industrial countries keep the high-tech goods." 156 In fifteen years, Thailand moved from being a rice producer to the world's second-largest producer of pickup trucks and fourth-largest manufacturer of motorcycles. ${ }^{157}$ For workers in the rich nations, then, jobs are moving overseas, but not just jobs in the traditional manufacturing or high-volume sectors. ${ }^{158}$ As markets become more international and open to increased trade and foreign direct investment, demand for information technology also increased, causing more companies to locate an even wider range of value-added activities overseas, such as research and development, procurement, accounting, and data entry and processing. ${ }^{159}$ Even

countries. See, e.g., Carol Stump, Comment, Free Trade Area of the Americas, 4 J. INT'L L. \& Prac. 153,168 (1995). Wood's study, published in 1994, stood in contrast with the conventional understanding of "[m]ost economists [who] have emphasized the role of technology, arguing that skillbiased technological improvements have reduced the relative wages of unskilled workers in the United States. ..." See John T. Addison et al., Technology, Trade Sensitivity, and Labor Displacement, 66 S. ECoN. J. 682, 682 (2000); Globalisation and Its Critics, supra note 48, at 9 (discussing a study by William Cline that shows that "technological change was perhaps five times more powerful in widening inequality in America between 1973 and 1993 than trade (including trade due to FDI [foreign direct investment])"); Workers of the World, Compete, THE EconomisT, Apr. 2, 1994, at 70 ("Many economists prefer to blame the dwindling demand for unskilled workers on the technological revolution of the past decade.").

See also Multinationals and the National INTEREST, supra note 140, at 10 (describing loss of jobs, export earnings, and tax revenues faced by governments when corporations move from one jurisdiction to another); THE CASE Agalnst THE Global Economy (Jerry Mander \& Edward Goldsmith eds., 1996). The apparent economic success of poorer countries, as seen in the rise in their exports, is considered "the single most important reason for the increase in European unemployment rates." See generally WES, supra note 79, at 2 (citing COMMISSION OF THE EUROPEAN COMMUNITIES, Growth, Competitiveness, Employment: The Challenges and Ways Forward INTo the 2IST CENTURY-WhTre PAPER, Office for Official Publications of the European Communities, Luxembourg (1993)).

156. War of the Worlds, supra note 146, at 24. Technological changes "mean that developing countries don't just have to trade their raw materials to the West and get finished products in return; they mean that developing countries can become big-time producers as well." FrIEDMAN, supra note 10, at xv, 45; see also WorLd DEVELOPMENT RePORT: WORKERS IN AN INTEGRATING WORLD 51 (1995).

157. FrIedman, supra note I0, at 46 .

158. Traditional ship-building countries such as Finland are seeing their shipbuilding industries relocate to countries such as Brazil, China, Taiwan, and the countries of Eastern Europe. GREIDER, supra note 20, at 62. Caterpillar also shifted production to overseas plants in Brazil, Europe, and Japan. Id. at 63 .

I59. See generally WIR 1993, supra note 110. China, India, Singapore, Hong Kong, and Taiwan established coinputer programming and equipment-design centers; created service industries, such as banking, accounting, and insurance; and globalized the preparation and handling of tax returns, insurance claims, and the processing of airline tickets. See GreIDER, supra note 20, at 66; Keith Bradsher, Skilled Workers Watch Their Jobs Migrate Overseas, N.Y. TMEs, Aug. 28, 1995, at A1. Outside of Bombay is a new, high-tech town known as SCEEPZ-the Santa Cruz Electronic Export Processing Zone-where transnational companies like Swissair and AT\&T hire Hindi-, Tamil-, and Mahratti-speaking coinputer programmers to write software. BAREER, supra note 1, at 18; see also Sanjoy Hazarika, An Indian City of the Future with the Lure of the Past, N.Y. TnMEs, Aug. 28, 1995, at D6. Call centers are thriving in India, as companies like GE and British Airways have established phone banks einploying Indian workers with fictional American lives to handle customer inquiries from 
without significant governmental resources to foster technology development, a number of small countries, most spectacularly, the Philippines, have nonetheless managed to become a center of information activities. ${ }^{160}$

ln many instances the global dispersion of production and investment has resulted in a divergence between the national and the corporate interests. While it had once been understood that the interests of the national corporations or the national champions were more or less aligned with the national interests, so that, for example, "what is good for General Motors is good for America," this alignment of interests can no longer be easily presumed. ${ }^{161}$ The corporation is no longer territorially confined to its home

the United States. Mark Landler, Hi, I'm in Bangalore (but I Can't Say So), N.Y. Times, Mar. 21, 2001, at Al (describing how customer service employees hired to field calls have set up fake telephone identities to convince Americans dialing toll-free numbers that the customer service employees work nearby; some watch American sitcoms such as Ally McBeal to learn the right phrases).

Where physical contact with customers is not essential, there is increasing scope for outsourcing to countries with cheap, but relatively well-educated workforces. People can be employed anywhere to carry out labour-intensive computer programming and data processing, keeping in touch with head office by computer network and satellite. Routine accountancy work, for example, could be subcontracted to developing countries.

War of the Worlds, supra note 146, at 24; Chen May-Yee, Let's Make a Deal, WaLl ST. J., Sept. 25, 2000 , at R10. Costa Rica, for example, successfully assembled an incentive package that included an eight-year income tax exemption, with a subsequent four-year period of $50 \%$ reduction in the country's $30 \%$ income tax rate, duty free import of raw materials, and free movement of capital-in order to land a $\$ 300$ million semiconductor test and assembly plant established by lntel outside the Costa Rican city of San Jose. May-Yee, supra.

160. "Even poorer places, and those without strong links to established innovation centers, can piggyback on the wide distribution of skills, knowledge, communications systems and capital around the world." G. Pascal Zachary \& Robert Frank, High-Tech Hopes, WaLl ST. J., Sept. 25, 2000, at R4. In the Philippines, "poor, largely rural students from remote villages [using] the most basic tools to ride the digital wave" have formed programming pools and attracted companies like Motorola and Anderson Consulting. Id. Web developers in Asia and Europe now send their design work to the Philippines, and engineering companies, like Bechtel Corporation, send blueprints to the Philippines at night and have them turned around and computer ready by the next morning. Id. America Online is building a world-wide service center at the former U.S. Clark Air Force Base where Filipino engineers and software experts work the e-mail system answering questions from AOL users in the United States. Id.

Other smaller countries that have managed to develop high-powered niches for certain technologies include: lsrael for "instant inessaging" technology, used in electronic mail; optoelectronics technology for China; and user interfaces technology for Mexico. Id. In an effort to become attractive technology sites, Costa Rica has eliminated import taxes on computer-related equipment, adopted an aggressive policy upgrading information technology facilities in schools, and strengthened its intellectual property laws. South Korea has an official policy of promoting e-business, with tight security standards for telecommunications centers. Hungary has invested heavily in information technology education, and all its secondary schools are connected through network computers. Estonia's Parliament approved a proposal to guarantee internet access as a matter of constitutional right for all its citizens, with the government setting "e-readiness" as its national priority. Ghana has become the first West African nation to attain connectivity in 1994. Id.

161. See generally ReICH, supra note 80 , at $43-68$; GREIDER, supra note 20 , at 76 . John Ruggie has termed this a breakdown of the "embedded liberal compromise" between capital and labor in the rich industrialized countries, which has also resulted in the state's adoption of a market-oriented approach to economic management to replace the Keynesian, state-oriented welfare approach that had characterized much of the post-World War II era. See John Gerard Ruggie, International Regimes, 
economy in the rich countries and could be lured to any country that offers the right combination of factors for increased profitability. ${ }^{162}$ These events have produced two significant changes. First, they have allowed poorer countries to exploit the increasing dispersal of capital to their advantage, reducing to some degree the raw power of the historically dominant nations to impose colonialist or neocolonialist terms of trade on the poorer countries. ${ }^{163}$ Second, however, it has also caused increased inequalities among certain groups within the advanced industrial societies, as companies shift their high-volume and even some high-value work from the richer to the poorer countries. ${ }^{164}$

This Article proposes that these substantive issues with distributive impact, both nationally and internationally, be addressed in a way that takes into account both the fact of globalization and the social and political context within which globalization itself must be engaged. For the free trade system to survive, it must have not just economic success but also political appeal. But before one can institute an effective economic regime that strikes a balance between the free trade orientation of the global economic system on the one hand and the protective concerns of national governments for their national economies on the other, one must first accurately understand what is meant by "national" and "international" as those terms have been employed and understood.

\section{Confusion: Dilemmas Underlying Current Trade Law and Policy}

It is time to reassess the extent to which the national corporation is still an appropriate conduit for national trade and imvestment policies. To use the United States as an example, because the benefits of U.S. trade

Transactions and Change: Embedded Liberalism in the Post War Economic Order, 36 INT'L ORG. 379, 379-415 (1982).

162. A brief examination of the history of American corporate law shows that individual states in the United States have also engaged in a competitive race to attract corporations by adopting liberal corporate enactment statutes. For example, New Jersey had long been aware of the revenue-generating aspects of corporate chartering; thus the New Jersey general incorporation act was the broadest and the most enabling, providing for a simple incorporating procedure and lenient residency requirements. See generally Gordon Tullock, Entry Barriers in Politics, 55 AM. ECON. REv. 458 (1965); ROBERT HeSSEN, IN DEFENSE OF THE CORPORATION 68-71 (1979). The New Jersey General Incorporation Act marked a complete shift from the states' initial hostility towards foreign corporations to one that welconed corporate business activities within their territories. GEORGE HEBERTON EVANS, Business INCORPORATIONS IN THE UNITED STATES, 1800-1943, at 11 (1948); Vicki Been, Exit as a Constraint on Land Use Exactions: Rethinking the Unconstitutional Conditions Doctrine, 91 CoLum. L. Rev. 473, 534 (1991). Delaware too has followed the New Jersey model and "bettered" it, allowing Delaware to assume leadership in providing and keeping a body of liberal corporate laws. See Andrew G. T. Moore, Preface to R. Franklin Balotti \& Jesse A. Finkelstein, The Delaware law of Corporations and Business Organizations H-1 I (3d ed. 1998); Bernard S. Black, Is Corporate Law Trivial?: A Political and Economic Analysis, 84 Nw. U. L. Rev. 542 (1990).

163. See supra notes $146-50$.

164. See supra notes 151-60; David R. Howell, The Skills Myth, AM. Prospect, Summer 1994, at 81. 
laws and policies are only available to American companies, what constitutes "American" has significant implications. ${ }^{165}$ But how or when a company or product qualifies as domestic is currently determined in piecemeal fashion by a system without clear rules or objectives.

Take as an example U.S. antidumping laws, one of the types of laws that regulate the importation of foreign products into the U.S. market. Dumping occurs when imports are sold in the United States at less than "fair value," that is, less than the price for home market or third market sales, and as a result, cause or threaten to cause material injury to a U.S. industry. ${ }^{166}$ Since the statute itself requires that the petition be made "on behalf of an industry," the antidumping laws are geared to the protection of a domestic industry from unfair practices. ${ }^{167}$ But the regulatory framework governing U.S. antidumping laws is one rooted in a time when U.S. industry meant U.S. companies, as traditionally understood. ${ }^{168}$ With the growing internationalization of production by corporate entities, the question of which party has standing to invoke the antidumping laws or which product is a U.S. versus a foreign product has become increasingly complicated. For example, in a proceeding initiated by Motorola, whereby Motorola claimed injury by less-than-fair-value imports of pagers from Japan, the definition of "domestic industry" became an issue when NEC, one of the Japanese importers, argued that Motorola should not be considered a domestic producer because Motorola itself imported pagers manufactured in its facilities in Malaysia. ${ }^{169}$ Which entity can be deemed part of the domestic industry is no longer simple when a domestic company (the

165. Examples of such trade laws include those designed to protect U.S. industry from unfair trade or import surges, those designed to open up foreign markets for U.S. companies, or those that condition certain government policy initiatives on the recipients being U.S. nationals or part of domestic industry. See Hilary K. Josephs, The Multinational Corporation, Integrated International Production, and the United States Antidumping Laws, 5 TUL. J. INT'L \& CoMP. L. 51, 59 (1997) ("Because special benefits accrue to the 'American' corporation and not to foreign corporations (including the ability to invoke the protection of U.S. laws), the tests for identifying corporate nationality are crucial. United States corporation law has not kept pace with changes in the economic reality.").

166. See Tariff Act of 1930, $\S$ 731-39 (1950), amended by 19 U.S.C. $\S \S 1673-1673(\mathrm{~h})$ (1994), and Urugnay Round Agreements Act, Pub. L. No. 103-465, §§ 21 1-234, 108 Stat. 4842-4901 (1995).

167. Article 5.1 of the GATT Antidumping Code states the following: "An investigation to determine the existence, degree and effect of any alleged dumping shall normally be initiated upon a written request by or on behalf of the domestic industry affected." Agreement on Implementation of Article VI of the General Agreements on Tariffs and Trade, Apr. 12, 1979, art. 5.1, 31 U.S.T. 4919, 18 I.L.M. 621 (1979).

168. Josephs, supra note 165 , at 54-55.

169. See Certain Radio Paging and Alerting Receiving Devices from Japan, USITC Pub. 1410, Inv. No. 731-TA-102 (Aug. 1983). NEC and Matsushita Communication Industrial Company argued that even if Motorola could be considered a domestic producer, any injury complained of by Motorola was only to products that were themselves imported. Matsushita also argued that injury to the domestic industry should be assessed only with respect to domestically produced pagers. The ITC held for Motorola, based on the overall nature of Motorola's activities in the United States, and concluded that Motorola's production of pagers, including those pagers partially assembled in Malaysia, are to be considered part of the domestic industry injured by less-than-fair-value sales of imports. 
producer) performs operations offshore and when a foreign company (the importer) performs some operations in the United States.

As complex as it is now to determine the nationality of a corporation, it is equally difficult and complex to determine the national origin of a product. In an investigation of an antidumping action involving forklifts, for example, the Commerce Department confessed that "strictly speaking, there was no such thing as a U.S. forklift, or a foreign forklift for that matter." ${ }^{\prime 170}$ Nonetheless, the agency determined that a forklift would be considered a U.S. forklift if its frame is manufactured in the United States, even if the remainder of its parts is made abroad. ${ }^{171}$ The rules that determine a product's national origin have become so convoluted that it is hard to tell whether they are designed to be part of a free trading system or to present barriers to trade. ${ }^{172}$

170. REICH, supra note 80, at 115.

171. Id.

172. Appearing before the Canadian Parliament to explain the various NAFTA provisions, then Canadian Trade Minister, Michael Wilson, said the following about rules of origin: "Rules of origin are very, very complex. You don't want to know about them. They are terrible things to deal with." John P. Simpson, North American Free Trade Agreement-Rules of Origin, 28 J. WorLd TRADE 33, 33 (1994). For example, in determining which products qualify as North American and are thus eligible for preferential tariff treatment by the member states, trade authorities must apply NAFTA rules of origin. Goods wholly originating in the NAFTA trade area qualify for tariff preferences. But goods that contain nonregional materials are still considered North American if those materials have been substantially transformed so as to undergo a change in tariff classification. North American Free Trade Agreement, Dec. 17, 1992, art. 401(b), H.R. Doc. 103-159, 32 I.L.M. 289, 349 [hereinafter NAFTA]. According to international standards, nationality of a product is determined by the nationality of the last country in which it underwent a "substantial transformation." Certain products, however, may also be subject to different and more specific rules of origin. For example, autos and light trucks must meet a specified $62.5 \%$ North American content. For computers, if the circuit board is made in North America and transformed in the region, the computer may be freely traded. RALPH H. FOLSOM ET AL., INTERNATIONAL Business TRANSACTIONS, 412-13 ( $2 \mathrm{~d}$ ed. 200I). Under special NAFTA rules, television sets, for example, count as "North American" and are exempt from various taxes only if they are not only assembled in North Ameriea but also contain North American made picture tubes consisting of the screen and the electron gun. Keith Bradsher, In Twist, Protectionism Is Used to Sell Trade Pact, N.Y. TIMEs, Nov. 7, 1993, at 26; see NAFTA, supra, annex 401, item 8528.10bb, 32 I.L.M. at 438; Mariana C. Silveira, Rules of Origin in International Trade Treaties: Towards the FTAA, 14 ARIZ. J. INT'L \& COMP. L. 411, 442 (1997). For example, a color television receiver with a screen size of more than fourteen inches is a NAFTA national only if the color picture tube originates in North America. NAFTA, supra, annex 401, item 8528.10bb, 32 I.L.M. at 438. A color television receiver with a screen size of less than fourteen inches must have all of the printed circuit boards and the tuner originate within the region. NAFTA, supra, annex 401, item 8528.10aa, 32 I.L.M. at 437. Assume that a television set is made in Mexico from component parts made in Mexico, Korea, and elsewhere. While the television set may not receive NAFTA preferential tariff treatment unless the color picture tube itself is manufactured within North America, the television may nonetheless be classified as a product of Mexico for marking or other purposes, such as the application of a countryspecific quota or an antidumping duty. For a discussion of rules of origin, see infra text accompanying notes 242-248. See also David A. Gantz, Implementing the NAFTA Rules of Origin: Are the Parties Helping or Hurting Free Trade? 12 ARIZ. J. INT'L \& CoMP. L. 367, 372 (1995).

Yet, this special rule for televisions does not necessarily assure that the product will be more "North American" and less "foreign." "[S]ince Japanese companies own large shares of both of the 'American' glass companies that manufacture tubes, 'American' domestic television sets will still be 
Without a thorough understanding of how globalization has produced a post-national economic system, international trade laws continue to rely on muddled notions of "nationality" to determine which company or which product is domestic or foreign. As a result, decisions are made on a scattered basis, guided by obsolete rules and short-term national interests. In some cases, countries found that traditional concepts of nationality were inadequate and needed to be revised, at least for the immediate cases at hand. For example, when France tried to limit Japanese automobile imports to $3 \%$ of the French market, Margaret Thatcher opposed the French move, as the Nissan Bluebirds were not only assembled in Britain but also composed of parts $80 \%$ of which came from Europe. ${ }^{173}$ Similarly, when Taiwan included Toyotas assembled in the United States in its ban on Japanese auto imports, the Bush administration was compelled to come to Toyota's defense and pressured Taiwan to back down. ${ }^{174}$

But at other times, traditional and anachronistic notions prevail and prevent countries from re-evaluating old premises. In 1986 when the Reagan administration negotiated a formal semiconductor agreement with Japan to provide a guaranteed market share to the U.S. semiconductor industry, and even as the U.S. government made the defense of its American semiconductor industry a centerpiece in its dispute with Japan, the U.S. semiconductor industry was already moving production abroad; from I982 to 1991, American jobs in this industry had suffered a $37 \%$ decrease, from 290,000 to $184,000 .{ }^{175}$ Motorola's workforce was increasing globally but its U.S. share was declining to $56 \% .{ }^{176}$ In 1989 , the Bush Administration used the threat of Section $301^{177}$ to force Japan to open its

substantially Japanese, even if they qualify as American under NAFTA rules." BARBER, supra note 1, at 25; see also Bradsher, supra at 26 . Asahi Glass of Japan owns $49 \%$ of the Corning subsidiary that makes glass for television screens, and Nippon Electric Glass of Japan owns a subsidiary of Owenslllinois, the other major U.S. producer of television screen glass.

173. REICH, supra note 80 , at 118.

174. Id.

175. GREIDER, supra note 20, at 91 . The same anachronistic notions of "American" corporate nationality prevail in the nontrade area as well and inform U.S. funding to Sematech, a consortium of American semiconductor companies such as IBM, Texas Instruments, Motorola, AT\&T, and others. Despite the initiative's overtly nationalist objectives, at least from the perspective of the U.S. government, the participating companies were clearly global in orientation: Texas Instruments began building a $\$ 250$ million semiconductor fabrication plant in Taiwan. It already had a plant in Kywhyu, Japan, and had also formed an alliance with Hitachi to design and make a new generation of superchips, as did Motorola in its alliance with Toshiba. AT\&T, too, paired up with Japan's NEC and Mitsubishi Electric; Intel with Japan's NMB Semiconductor Company and Matsushita Group, and IBM with Germany's Siemens. In other words, "the consortium was in fact little more than a partnership among several emerging global webs whose future would be only tangentially related to the future skills of Americans." ReicH, supra note 80, at 161 . Ironically, a Japanese company, NEC, which was constructing a $\$ 400$ million advanced-chip fabrication facility in Rosevale, California, was not permitted to join the Sematech consortium. See also What Is a U.S. Company Hearings, supra note 129 , at 36, 37-39 (statement of Dr. John Kline).

176. GREIDER, supra note 20, at 91 ; see also Uchitelle, supra note 137.

177. See Trade Act of 1974, Pub. L. No. 93-618, § 301, 88 Stat. 2011, 2041 (1976). 
market to Motorola. ${ }^{178}$ At that point, despite its formal "American" corporate nationality, Motorola's production facilities were primarily in Kuala Lumpur, Malaysia. ${ }^{179}$ In 1995, Motorola announced that it was locating its new $\$ 750$ million wafer fabrication plant not in the United States but in China. ${ }^{180}$

Although globalization of the firm and its products has resulted in a convoluted concept of "national" identity and thus created awkward contradictions in the way trade law is conducted, there is as yet no comprehensive re-evaluation of corporate "nationality" 181 in the international trading system. What is a domestic corporation or a foreign corporation if its operations can be found in multiple national territories outside its home state? ${ }^{182}$ Corporate nationality has been determined by using a number of

178. RE1CH, supra note 80, at 164.

179. Uchitelle, supra note 137.

180. GREIDER, supra note 20, at 91, 214 (describing the movement of operations to Asia by U.S. auto parts producers); see also Helene Cooper, What Is the Luxury-car Fight About? A Primer, Wall St. J., May 18, 1995, at A2. Similarly, when the Clinton Administration was approached by both Northern Telecom, a Canadian firm, and AT\&T, an American company, for the Administration's support of their respective bids to win the phone franchise in China, the U.S. government backed AT\&T, presumably because it is an American company. Northern Telecom, however, promised to manufacture the hardware in its U.S. factories, and AT\&T made no such promise. AT\&T was ultimately awarded the franchise after it agreed to build two new factories for advanced switching equipment, both in China. GrelDER, supra note 20, at 213. Companies that have moved their manufacturing operations abroad counter the suggestion that they are shedding their ties to the United States. When Robert Reich suggested to the Federal Communications Commission that it choose a high-definition-television standard based in part on which system would. create "the greatest contribution to domestic high-wage employment," the chairman of Zenith, which assembles many of its television sets in Mexico, argued that the issue should not be where the high-tech television sets are assembled but where the semiconductor circuitry originates. Magnusson, supra note 107, at 142. Thus while European companies might have moved some of their assembly operations to the United States, the high-value-added jobs have renrained in Europe. $I d$. Accordingly, Zenith, by offering to buy components from AT\&T's Florida and Pennsylvania chip factories, should rank above the European companies in terms of U.S. trade priorities.

181. The concept of "nationality" was initially thought to be inapplicable to a corporation, because "national" connoted a sense of personal allegiance towards the sovereign which only a natural person could have. See Herman Walker, Jr., Provisions on Companies in United States Commercial Treaties, 59 AM. J. INT'L L. 373, $377-78$ (1956); E. Hilton Young, The Nationality of a Juristic Person, 22 HARV. L. REV. 1, 2 (1908) (objecting to the application of the word "nationality," which carries certain implications of political duties and allegiance, to a corporation). In modern U.S. law, the notion of corporate nationality is fully accepted. See generally Yitzhak Hadari, The Choice of National Law Applicable to the Multinational Enterprise and the Nationality of Such Enterprises, 1974 DUKE L.J. 1, 3 [heremafter Hadari, Choice of National Law]; Heinrich Kronstein, The Nationality of International Enterprises, 52 Colum. L. Rev. 983 (1952).

182. Citations infra notes $183-87$ to works on corporate nationality are drawn from conpilations in Hartwin Bungert, Equal Protection for Foreign and Alien Corporations: Towards Intermediate Scrutiny for a Quasi-suspect Classification, 59 Mo. L. Rev. 569, 677 un.2, 4, 5 \& 6 (1994). See 17 William Meade Fletcher et al., Fletcher Cyclopedia of the LaW of Private CoRporations $\$ 8290$ (perm. ed., rev. vol. 1987) for a widely accepted definition of corporate nationality ("With respect to a particular state or country, a corporation created by or under the laws of that state or country is a 'domestic corporation' and any corporation that owes its existence to the laws of another state, government or country is a "foreign corporation."'). 
tests. ${ }^{183}$ First, the traditional incorporation test looks to where a corporation is incorporated.$^{184}$ Under this test, a corporation is a mere artificial person and therefore "can have no legal existence out of the boundaries of the sovereignty by which it is created. ... It must dwell in the place of its creation, and cannot migrate to another sovereignty."185 Second, the socalled control test determines corporate nationality by looking to the nationality of its stockholders and others, such as officers, directors, and managers, who exercise control over its affairs. ${ }^{186}$ And third, corporate nationality has been assigned by reference to the seat test, which looks to the state where the center of a company's management is located. ${ }^{187}$

183. The tests for corporate nationality are described infra notes 184-87. However, "[i]nternational law does not provide a single, agreed answer to the problem of corporate nationality ..." Michael P. Avramovich, The Protection of International Investment at the Start of the Twenty-First Century: Will Anachronistic Notions of Business Render Irrelevant The OECD's Multilateral Agreement on Investment? 31 J. MARSHALL L. REv. 1201, 1223 (1998); see also John H. Merryman, Nationality of the Corporate Person, 22 Notre DAME L. REv. 181 (1947) ("No one rule for the determination of nationality has been accepted by the various nations ....").

184. There are two primary and competing theories for determining corporate nationality: test of incorporation and the place of the corporate "seat." In the U.S and other common law countries, corporate nationality traditionally has been determined by reference to a corporation's place of incorporation. See Restatement (THIRD) OF Foreign Relations LAW § 213 (1986) ("For purposes of international law, a corporation has the nationality of the state under the laws of which the corporation is organized."); see also Hadari, Choice of National Law, supra note 181, at 7-11. Where a corporation was incorporated is easily ascertainable; thus the place of incorporation test also has the advantage of providing clarity and predictability in choice-of-law matters. See id. at 10. For a discussion of the seat test, see infra note 187.

185. Bank of Augusta v. Earle, 38 U.S. (13 Pet.) 519, 588 (1839).

186. The shareholder nationality or control test gained ascendancy as an alternative approach to determining corporate nationality in the early-twentieth century due to national security concerns and to fear of "alien capital," as corporate nationality became crucial in the application of the Trading with the Enemy Acts. See Hadari, Choice of National Law, supra note 181, at 23-25; Detlev F. Vagts, The Corporate Alien: Definitional Questions in Federal Restraints on Foreign Enterprise, 74 HARv. L. Rev. 1489, 1527 \& n.181 (1961); R.E.L. Vaughn Williams \& Matthew Chrussachi, The Nationality of Corporations, 49 LAW Q. REv. 334, 337-39 (1933). In a landmark English decision, the British court looked to the shareholders and directors, rather than the law of incorporation, to determine whether legal "control" was in the hand of the enemy. See Daimler Co. v. Continental Tyre \& Rubber Co., 2 App. Cas. 307, 340-41 (1916); see also Society for the Propagation of the Gospel v. Wheeler, 22 F. Cas. 756, 2 Gall. 105 (C.C.D.N.H. 1814) (No. 13,156) (holding that because a corporation incorporated in England was an alien in the United States, it became an alien enemy when England and the United States declared war on each other). For a discussion of the control test and its use in determining corporate nationality in various treaties, see Walker, supra note 181 , at 381 n.39.

187. Most continental countries adhere to the seat rule, that is, the principal place of business or central administration of the company, with the place of the corporate headquarters being the dominant factor in this inquiry. Hadari, Choice of National Law, supra note 181, at 8-9. Some countries look to the place where the board of directors or the shareholders meet. Id. This has also been referred to as the "location of control" test, which involves an examination of where management decisions are taken. See M. Tedeschi, The Determination of Corporate Nationality, 50 THE Australian L.J. 521, 522 (1976). The test of incorporation, along with the seat test, was adopted by the International Court of Justice in Barcelona Traction, Light and Power Co., 1970 1.C.J. 3, 43 (Feb. 5) (dismissing a petition by Belgium, which espoused the claim of Barcelona Traction, because the place of the company's incorporation was in Canada); see also Moshe Hirsch, The Arbitration Mechanism of the InTERnational Centre for the SetTlement of INVestment Disputes 82 (1993). 
These tests are ill suited for the postnational economy. ${ }^{188}$ When corporate production, operation, and organization are no longer localized, as Part II.A shows, the mere fact that a corporation is organized under the law of its state of incorporation does not in itself reveal significant or meaningful connection or identification with that state. ${ }^{189}$ Similarly, the nationality of the corporation's shareholders, or its directors, officers, and nuanagers, as used in the control test, is equally ineffective. First, given the frequency and ease with which shares change hands, nationality determinations based on ownership of equity is potentially inaccurate because share ownership is unlikely to be frozen or fixed. ${ }^{190}$ Second, focusing on equity ownership and

188. See generally Avramovich, supra note 183, at 1226 ("[T] he traditional tests governing corporations are becoming increasingly less useful in an economic world where economic decisionmaking is devolving and the corporation merely represents a network of intellectual capital and relationships."); Phillip I. Blumberg, The Multinational Challenge to Corporation Law: The Search for a Neiv Corporate Personality 232-33 (1993) (expressing a general dissatisfaction with current tests and proposing a test that treats all affiliated corporations of a corporate group as one "enterprise," noting that "the concept of the corporation as a separate legal entity, a concept which origimally had satisfactorily defined the economic entity as well as the legal entity, has failed to correspond to the modem realities of American and world busmess"); see also Phillip I. Blumberg, The Corporate Entity in an Era of Multinational Corporations, 15 DEL. J. CoRP. L. 283, 299 (1990).

189. This test is widely used. The Restatement states that for purposes of intemational law, a corporation's nationality is that of the state under which the corporation is organized. See RESTATEMENT, supra note 184. Reporter's Note 5 of the Restatement also noted that the general assumption under U.S. law is that the place of incorporation determines corporate nationality. That test, however, has also been criticized. See M. Tedeschi, supra note 187, at 521. Tedeschi described the place of incorporation test as:

the least sophisticated way of determining the nationality of a corporation, in that it takes the concept of nationality of natural persons and applies it to the corporate sphere by stating that a corporation, if "bom" in a jurisdiction, becomes a subject there. In this era of increased corporate mobility, the choice of the place of incorporation may be purely a matter of convenience without any intention on the part of those who manifest the corporate will to have any other connection with the jurisdiction of incorporation.

Young, supra note 181, at 5. Young notes that the test of mcorporation is madequate because the state: has done nothing in connection with [the corporations'] institution; it has merely tacitly assented to their creation, and can in no sense be said to have created them itself, or to have performed any other act from which it is possible to construe an intention on its part to endow them with its nationality.

Stanley J. Marcuss \& Eric L. Richard, Extraterritorial Jurisdiction in United States Trade Law: The Need for a Consistent Theory, 20 Colum. J. TRansnaT'L L. 439, 469 (1981) (discussing how the test, if used without reference to other considerations such as connections of the corporation in other ways to the state, is madequate and simplistic); see generally H.F. vaN PANKUYY, THE ROLE OF NATIONALITY IN INTERNATIONAL LAW (1959); Kronstem, supra note 181, at 990.

190. "Even when an ownership or control determination is made at a given point in time, this 'snapshot' picture of corporate nationality can soon fade...." What Is a U.S. Company Hearings, supra note 129, at 34. "With increased dispersion of share-holdings through global stock exchanges, tracing ownership and control variables among transnational corporate alliances would be a constant and challenging definitional task." Id. at 35 (testimony of Dr. John Klme); see also M. Tedeschi, supra note 187, at 523 (discussing "difficulty ... of tracing ownership and voting rights"); Young, supra note 181, at 3 (critiquing the control test because the "nationality of the majority of [shareholders], or of the holders of the major part of the common capital, may and often actually does fluctuate rapidly"). An additional problem with the test is that "control" has been determined primarily by reference to shareholder control, rather than to control by corporate officers, directors, and managers, who may in 
equity control is likely to present an incomplete and misleading picture, because of the proliferation of transnational intercorporate alliances that are highly significant and strategically important, even though they may be low or nonequity arrangements. ${ }^{191}$

The premises underlying the control test are also questionable in the global economy. While a corporation's profits may be used to pay shareholder dividends, which may in turn be reinvested in the local economy, there is a great likelihood that, with the increase in cross-border capital investment, shareholders will invest their profits in countries other than their countries of citizenship. ${ }^{192}$ Additionally, shareholder interest (maximizing share value for its shareholders through globalized production) and the local community interest (preferring local production) or the larger national interest may not always coincide. ${ }^{193}$ The control test ignores this reality by labeling a corporation more "American" merely because its shareholders are U.S. nationals.

The control test may be useful to the extent that it looks beyond the formality or facade of where the corporation is incorporated, or where it does business, to allow inquiry into where control "truly" lies. It is not,

fact exercise greater control in a public corporation than the shareholders do. See Sigmund Timberg, Corporate Fictions: Logical, Social and International Implications, 46 CoLUM. L. REv. 533, 562-63 (1946).

191. For example, a consortia program like Sematech that uses shareholder ownership criterion to determine a national company would have to impose an additional requirement to "freeze" the equity holding of the controlling shareholder. Again, even proponents of this criterion recognize the difficulties of their proposal. See What Is a U.S. Company Hearings, supra note 129, at 48 ("[S]ome of the most innovative companies ... can change ownership into a foreign situation, but that just brings up the same question again... and that is, should there be some limitations on key technologies as respects corporate acquisitions?") (testimony of Larry Hecht, Executive Director of the lacocca Institute, Lehigh Umiversity). However, a requirement that eligible corporate participants must "maintain their same operational characteristics indefinitely ... would inhibit their ability to embrace technological change and would isolate them from the marketplace," given their propensity to engage in cross-border equity and nonequity strategic alliances. Id. at 34 (testimony of Dr. John Kline).

192. From 1980 to 1994 , Americans invested a total of $\$ 1.5$ trillion in foreign securities. See, e.g., Russell B. Scholl, The International Investment Position of the United States in 1996, in U.S. DEP'T OF COMMERCE, JULY 1997: SURVEY OF CURRENT Business, at 24, 26-27, 30, available at http://www.bea.doc.gov/bea/ai/0797iip/maintext.htm (last visited Jan. 16, 2002). In 1996, U.S. investors had \$176.4 billion of foreign stocks and $\$ 42.7$ billion of foreign bonds; conversely, foreign investors held \$1,225.5 billion of U.S. securities. Id; see also Ted C. Fishman, The Joys of Global Investment: Shipping Home the Fruits of Misery, HARPER's MAG., Feb. 1, 1997, at 35.

193. See, e.g., Evelyn Iritani, In Global Economy, U.S. Job Gains, Losses Know No Borders, L.A. Times, pr. 6, 2001, at Al. Discussing corporate decisions to shift production, Tom Duesterberg, president and chief executive of the Manufacturers Alliance, a Washington group of 450 leading U.S. manufacturers, said, "Most of these decisions are being made more on the basis of the economics of the situation rather than what would be a more traditional concern of protecting the local community." Id.; Avramovich, supra note 183, at 1229-31 (critiquing the underlying presumption that shareholders act in the national interests inhercnt in the control test); Young, supra note 181, at 2 (criticizing the notion of allegiance assumed in the term "nationality"). To the extent that the control test relies on shareholder control, and by implication shareholder allegiance, it would bc susceptible to the same critique offered by Young. 
however, useful if it assumes that shareholders or other control persons make corporate decisions based on their citizenship obligations ${ }^{194}$ (as opposed to economic or corporate interests). Shareholders are principally motivated by the objective of maximizing their investments, and officers and directors are similarly duty-bound to achieve this objective for their shareholders. ${ }^{195}$ Under the business corporation laws of many states in the United States, for example, controlling shareholders as well as directors and officers owe a fiduciary duty of loyalty to the corporation, including its minority shareholders. ${ }^{196}$ In a fiercely competitive and global economy, the controlling shareholders', directors', and officers' decision-making processes are not normally determined by issues of citizenship, but rather, business principles. ${ }^{197}$ Moreover, under certain circumstances, companies owned by foreign nationals, more than "home grown" companies, may be less likely to pull out of a foreign market in the event of an economic downturn and more likely to adopt a long-term economic view, precisely because they have incurred large "sunken" costs to enter the market to

194. See Timberg, supra note 190, at 566-74. The Article questions the assumption that controlling groups make decisions based on corporate benefit rather than personal advancement and asserts that the conflict between self-interests and corporate interests, as well as self-interests and "political allegiance to [the] sovereign state" is quite common. Id. at 572. Modern day critics have made similar observations. Critics have charged that the elite group of symbolic analysts, those engaged in "problem-solving, problem-identifying, and strategic-brokering activities," REICH, supra note 80 , at 177 , or "high tech nomadic tribe ... [have] more in common with each other than with the citizens of whatever country they happen to do business in." JEREMY RIFKIN, THE END OF WORK 176 (1995); see also Falk, The Making of Global Citizenship, supra note 66, at 44 (describing the emergence of a cross-national business and financial elite that has more in common with those within its membership than it does with other nonelite workers in its own national community); CHRISTOPHER Lasch, The Revolt of the Elites and the Betrayal of Democracy 47 (1995) ("The denationalization of business enterprise tends to produce a class of cosmopolitans who set themselves as 'world citizens, but without accepting ... any of the obligations that citizenship in a polity normally implies." "); REICH, supra note 80, at 208-24 (describing "secession" by the elites who have profited the most from the global econoiny into their separate commumities).

195. See Am. L. Inst., PRinciples of Corporate Governance ANd Structure $\$ 2.01$, at 55 (1994). This does not mean that corporate managers cannot consider other interests besides shareholder interests. N.Y. Bus. CoRP. LAw \$ 717(b) (Consol. 2001) (other stakeholder section) see also Unhappy Fanilies: Stakeholder Capitalism, THE ECONOMST, Feb. 10, 1996, at 23 (discussing how public companies in Japan and in Continental European countries generally adopt a broader vision of the duty of their corporate managers, as one that encompasses the interests of other stakeholders, such as enployees, suppliers, and the communities in which they operate).

196. See, e.g., N.Y. Bus. Corp. Law \$ 717(b), supra note 195 (indicating duty of directors includes the duty to consider the interests of the corporation and its shareholders).

197. See What Is a U.S.Company Hearings, supra note 129, at 117. According to Mark Rochkind, then President of Philips Labs, North American Philips Corporation:

all of the businesses, those that are so-called foreign owned[,] those that are so-called American owned, are driven by business practice which seeks to make a busimess success of their endeavors. The result is that Philips chooses to invest, manufacture, and sell in the American market. Another result: Certain American-owned corporations, for very good business reasons, exercise business judgment and not economic nationalism and choose to do some R\&D and product development and manufacture abroad. 
begin with. ${ }^{198}$ Such companies (even if owned or controlled by foreign decision makers) are in that sense even more "loyal" to the country where significant investments are located than are "home-grown" companies.

From the standpoint of the proposal, which aims to balance the local with the global, the seat criterion would also not be appropriate because nationality is conferred on the basis of management's location, that is, the place that serves as the decision-making center of the corporation. ${ }^{199}$ In fact, the seat test reflects a quintessentially internationalist bias at the expense of that which is usually associated with the national territory; it privileges the position of global elites in conferring nationality. As such, the test would provide global companies with no incentive to demonstrate a commitment to or establish roots in any one country because no economic benefit would be derived from such a commitment under the seat test of corporate nationality. The test also ignores other factors, such as the location of labor and the company's investment and other assets that anchor the company in the territory of a particular state.

To accept that corporations have become global in orientation and operations does not mean, however, that they have transcended the nationstate $^{200}$ or have no "nationality." It is evident, for example, that a company can be formed only pursuant to the law of a particular national jurisdiction and not pursuant to international law. To that extent, at the very least, its corporate behavior and strategy are certainly influenced by the legal environment of that country's corporations law. ${ }^{201}$ The concept of corporate nationality itself is not obsolete, but rather, the old tests for determining corporate nationality are misleading as globalization progresses. Given the new economic shift, from national to global, a different concept of corporate "nationality" is therefore needed, one that balances the appeal of nationalisin with the demands of internationalism.

III

\section{Towards a New Meaning of Nationality in the Global Economy}

As Part II.C reveals, there is currently no comprehensive assessment of the meaning of "nationality" and "origin" in an international economy becoming increasingly postnational. U.S. trade laws, like the trade laws of

198. See Deanne Julius, Global Companies and Public Policy 65 (1990).

199. See generally Societe Constr. Ltd. v. Brown, 1897 Journal du Palais 84, 1897 Journal DE TribunauX DE COMMERCE 552; M. Tedeschi, supra note 187, at 524 (discussing how the "location of central management and control... becomes little more than a fiction" if the seat criterion is determinative for corporate nationality while major corporate assets are elsewhere); Young, supra note 181 , at $18-25$.

200. For the argument that nationality still matters, see, for example, D'Andrea Tyson, supra note 8, at 37; Magnusson, supra note 107, at 142 .

201. The corporations law of a country necessarily affects corporate behavior because what is legal, permissible, or mandated in one country may be illegal and prohibited in another. For example, codetermination may be required in German corporate law but not in U.S. law. 
many countries, are designed to grant certain beneficial considerations to and protective measures for domestic companies and their products against certain acts by foreign companies and foreign products. For example, there are laws designed to protect domestic industry ${ }^{202}$ and laws that correct "unfair trade." 203 In a globally integrated economic system, however, it is not always easy to differentiate the "domestic imdustry" seeking the protection and the "foreign" importer alleged to be injuring domestic industry. One of the questions raised thus is one of standing: in invoking the protection provided by the relevant laws, is the plaintiff "domestic" and thus eligible for relief? Even in the foreign investment area, where the United States has been generally less hostile to foreign investment than other countries, it too has looked upon foreign investment with sonie degree of suspicion and anxiety, as evidenced by the concern exhibited in the 1990s over a supposed "foreign takeover" prompted by the nuflux of Japanese capital in manufacturing and high-tech industries. ${ }^{204}$

Part III advocates a new way of thinking about nationality that is compatible with the global framework laid out in the Article. Part III.A focuses on revising corporate nationality. The proposed corporate nationality test allows any corporation, wherever incorporated or seated and however controlled, to be deemed a national of a state if that corporation meets a domestic participation test. Global corporations that qualify under the test are given certain "offset benefits" as incentives to demonstrate national

202. For example, one of the measures used by the United States as a buffer against imports is the escape clause contained in Section 201 of the Trade Act of 1974, which allows a member of a "domestic industry" to seek temporary relief from imports upon proof that an increase in imports substantially causes or threatens to cause serious injury to domestic industries producing like or directly competitive articles. Trade Act of 1974, Pub. L. No. 93-618, § 201, 88 Stat. 2011 (1975), amended by Trade Agreements of 1979, Pub. L. No. 96-39, §\$106(b)(3), 1106 (d)(1)-(7), 93 Stat. 193, 312, and Trade and Tariff Act of 1984, Pub. L. No. 98-573, $\$$ 248(a), 249, 98 Stat. 2998 (codified at 19 U.S.C. $\S 2251$ (1994)). Section 201 is the domestic statute that implements U.S. obligations under Article XIX of GATT.

203. Unfair trade laws, such as the antidumping laws, may be invoked when a "domestic industry" alleges that imported items are being sold at less than fair value, thereby causing it material injury. 19 U.S.C. $\$ 1673$, et seq. (1994).

204. Gregory W. Noble, Takeover or Makeover? Japanese Investment in America, 34 CAL. MGMT. Rev. 127 (1992). Japanese firms have provided many Silicon Valley startups with capital in exchange for access to or control of new technologies. Some expressed concern when Japanese real estate developers bought the Rockefeller Center, Pebble Beach, Heavenly Valley, and portions of downtown Los Angeles. When Sony bought Columbia Pictures in 1989, Newsweek ran a cover of the Statue of Liberty clothed in a kimono.

The exaggerated perception of a foreign "invasion" coupled with the concern that the sale would give Fujitsu control over chip technologies contributed to the Commerce Department's opposition in 1986 to the proposed sale of Fairchild Semiconductor Corporation to Fujitsu. Id. Ironically, despite proclamations that the "U.S. industry" must be protected, Fairchild was not even an "American" firm at the time because it was already controlled by the French oil field services firm, Schlumberger. "Nationality of ownership should have been irrelevant." REICH, supra note 80, at 155 . For an analysis of why traditional understandings of nationality should not determine U.S. policy on which companies are allowed to participate in U.S. technology programs, see id. at 154-68. See also What Is a U.S. Company Hearings, supra note 129. 
attachment. The proposal champions trade liberalism and favors engaging with, rather than opposing, the global economy. It does so, however, not by reference to the conventional internationalist sensibility that typically reflects a free-floating perspective detached from particular political communities. Rather, the internationalism the test embodies is a rooted internationalism, where international economic activities flow from, rather than transcend, national life.

Part III.B focuses on revising rules of origin. To the extent that rules of origin are part of, and not eliminated from, the trade regime, they should be reexamined to address the additional complications posed by the globalization of economic activities. Because it will not be politically feasible, in all likelihood, to have one simple set of rules for all products, ${ }^{205}$ Part III.B is only intended to offer an alternative framework for determining mles of origin. This framework, I argue, should favor a broad interpretation of rules of origin, primarily in two categories: those in lower-skilled operations and those in the postindustrial service economy. These revisions will allow trade rules to better reflect the global transformations identified in the Article.

205. The working committee established by the WTO Agreement on Rules of Origin has been working since the establishment of the WTO on sector- and product-specific rules of origin. See Agreement on Rules of Origin, Apr. 15, 1994, Marrakesh Agreement Establishing the World Trade Organization, art. 2(a)-(c), available at http://www.wto.org/english/docs_e/legal_e/final_e.htm [hereinafter WTO Rules of Origin]; see also infra note 285. Similarly, origin rules im NAFTA, for example, are also different for different products, such as television sets. See supra note 172. The existenee of separate rules for individual products may reflect the incumbent economic interests of those domestic interest groups that have organized to ensure that domestic nationality is not easily conferred. See Silveira, supra note 172, at 420. "Political considerations, sectorial interests and protectionism" are barriers to achieving simple rules of origin. Id. at 417,449; see also Kevin Merida \& Tom Kenworthy, For Some a Bitter NAFTA Taste, WASH. Post, Nov. 18, 1993, at Al (noting that to secure votes for NAFTA, President Clinton had to make deals ensuring special treatment for sugar, citrus, vegetable, beef, peanuts, and other products). 


\section{A. Reforming Corporate Nationality: A Proposed Domestic Participation Test ${ }^{206}$}

The proposed domestic participation test flows from the observations in Part II. The key point may be summarized in the following way: because the global dispersion of economic activities has rendered problematic traditional economic distinctions founded on an "us" versus "them" or a "national" versus "international" market, to the extent that a "national" market can be accurately identified at all, its identification does not derive any longer from a "domestic" corporation or a "domestic" product, but a "domestic" work force that for the most part is still territorially bound. The primary purpose underlying the new proposed test is to ensure that trade and investment from whichever source can be drawn into the national territory of a state and in the process generate positive economic opportunities for its people. ${ }^{207}$

206. The articulation of this test builds on my prior work on the implications globalization poses for international economic development, where I argued for a conceptual approach that focuses on human capital, that is, on the home work force and how it might benefit from value-added activities drawn from global companies, rather than on protecting "home" corporations, as that concept has been traditionally understood. See Lan Cao, Toward a New Sensibility for International Economic Development, 32 TEX. INT'L L.J. 209, 259-70 (1997). The domestic participation test proposed in this section was also inspired by Heinrich Kronstein. Kronstein, supra note I8I, at 984 . As early as I952, Professor Kronstein recognized that there might be a disjuncture between the traditional test of corporate nationality and the economic reality of corporate economic activities:

Assuming that it is legal theory which should adjust to economic reality and not the reverse, it follows that any "divergence between corporate theory and the underlying economic facts" should be resolved in favor of the latter. Such a divergence does exist, and, despite it, corporate theory has been slow to change. For example, a factory in the United States is an integral part of the American economy although it may be owned by foreign interests. Yet recognition of its status as an American busimess enterprise does ... depend on the fortuitous fact of whether it is or is not incorporated in an American state. If not, it inay be considered to have no existence distinct from that of the home office abroad even though, as a matter of reality, it is a distinct enterprise entrenched in the United States economy.

Id.

The proposed domestic participation test might be analogized to similar instances where U.S. courts have been faced with jurisdictional cases dealing with multistate corporations. See Hadari, Choice of National Law, supra note 18I, at II (commenting that in cases where a manufacturing company in which "most of the business operations and day-to-day management were carried on in one state, while the overall management and control of the corporation were exercised from another state ... the United States courts have tended to find the former to be the corporation's principal place of business"). A focus on significant business contacts, as evidenced by the courts' inquiry into the company's principal business operations, is analogous to my proposal to focus on the corporation's degree of domestic participation in a state. The proposed domestic participation test is also analogous to the traditional "primcipal place of business test." The principal place of business test "involves locating the production or processing of goods or services, the extraction of raw inaterials, or the investment of capital." See Tedeschi, supra note 187, at 522. For a discussion of another version of the principal place of business test, see What Is a U.S. Company Hearings, supra note 129, and Linda A. Mabry, Multinational Corporations and U.S. Technology Policy: Rethinking the Concept of Corporate Nationality, 87 GEO. L.J. 563 (1999).

207. As the former President of Philips Labs, whose parent company is Dutch-owned, remarked: "As we examine what it means for a nation to be competitive, we must ask questions not 
The first and foremost area of inquiry is to ask the following question concerning a corporation's nationality: do the corporate activities within the state qualify as substantial, socioeconomic participation in the state's economy? If the answer is yes, then the corporation qualifies as a domestic firm, entitled to the benefits and protection of the applicable trade laws. The second part proceed as follows: assuming that a company meets the domestic participation inquiry and qualifies as a domestic company, it is entitled to a "participation offset" right. With the offset right, the company can offset any duties, tariffs, and other protective measures ${ }^{208}$ that it may be subject to under current law, up to the amount calculated to be its "net total" participation in the domestic economy. This proposed offset would be available only to companies that qualify as "domestic."

By making the offset right conditional on the company's domestic nationality, which in turn requires the company to demonstrate "substantial," "socioeconomic" participation, the test directly addresses the reality of globalization: corporate capital mobility. A global company is domestic only if it meets the participation test, which is itself a test grounded in territorial or national considerations to balance the global with the local.

\section{Step One: Substantial Socioeconomic Participation \\ a. Substantial}

A company's "substantial" participation may be expressed as a "percentage" test, in which the amount of participation in question is compared to the corporation's overall financial interests and activities. Or it also may be expressed as a "quantity" test, in which one looks at whether the amount of participation is sufficiently large to qualify as "substantial."

about its corporations but about its work force. More and more, it becomes clear that a competitive work force is characterized by skills, training, knowledge, and technological sophistication." What Is a U.S. Company, supra note 129, at 76 (testimony of Mark Rochkind). Indeed, today's global economy, ironically, has made the local all the more significant. "Prosperity in a nation is a reflection of what both domestic and foreign firms choose to do in that nation." Michael E. Porter, Attitudes, Values, Beliefs, and the Microeconomics of Prosperity, in Culture Matters: How Values Shape Human PRogress 16 (Lawrence E. Harrison \& Samuel P. Huntington eds., 2000). "Domestic firms that produced low-quality products using unsophisticated methods hold back national productivity, whereas foreign firms that bring in new technology and advanced methods will boost productivity and local wages." Id. Given the rapid movement of capital, technology, and information, and the ease with which companies (and their competitors) can now source their inputs globally, global outsourcing, while necessary as a business practice, no longer confers a competitive advantage vis-a-vis other companies. As a result, "[t]he remaining sources of competitive advantages are increasingly local," id. at 17 , such as the national or local work force, "special supplier or customer relationship, unique insights about market gleaned from local customers or partners, special access to technology and knowledge from other local institutions, or production flexibility resulting from the use of a nearby supplier." Id. at 17 .

208. If an escape clause proceeding grants protective relief, such as Section 201 of the Trade Act of 1974, the protective measures may include increased tariffs or tariff rate quotas (tariffs which increase only after a certain quota for the imported item has been reached). See Trade Act of 1974, 19 U.S.C. $\$ 2253$ (a) (2000). 
Courts have used both approaches in evaluating "substantiality" in other areas of law, ${ }^{209}$ and for the most part have held that "each case must be decided on its own facts"210 in determining whether or not a company derives "substantial revenue" from goods used or consumed in a state.

Under either test, whether or not the economic presence counts as "substantial" will depend partially on the history of the corporation, the nature of the industry, and the level of economic development of the country at issue. The evidence required to demonstrate substantial participation is evidence concerning tax revenues; production and employment levels; systematic activities in the domestic economy that significantly utilize land, labor, and intellectual and financial capital for the creation of value domestically; domestic linkages with suppliers and subcontractors; reinvestment of earnings in the country in question; and research and development. ${ }^{211}$ A company wishing to prove the extent of its domestic

209. New York courts have found that a corporation may be subjected to personal jurisdiction in New York if the company derives "substantial revenue" in the state. See, e.g., Allen v. Canadian General Electric Co., 410 N.Y.S.2d 707 (N.Y. App. Div. 1978), affd 431 N.Y.S.2d 526 (1980). ln determining "substantial revenue," the court noted that "[o]nly a small portion of [the company's] total sales of goods and services are made to customers in New York State..." which was less than 1\% of total sales of $\$ 879$ million in 1976. Id. at 708. This meant that revenue in New York was $\$ 8.79$ million. The court noted that although the New York statute itself provided no firm guidance on the interpretation of the term "substantial revenue," "[w] hether a 'quantitative' or 'qualitative' approach is used, the sum of $\$ 8.79$ million is too large to be considered insubstantial without further analysis or proof of the business which would show such fact." Id. at 709. Under the quantity test, the actual amount, though only $1 \%$ of the company's total sales, is still prima facie "substantial" to support jurisdiction. Id.; see also Gillmore v. J.S. Inskip, Inc., 282 N.Y.S.2d 127 (Sup. Ct. Nassau County 1967). The court determined that "substantial revenue" should be interpreted to "require comparison of New York (or interstate or international) gross sales revenue with a defendant's total gross sales revenue or New York, interstate or international net profits with a defendant's total net profit ...."Id. (citation omitted). The court also noted, however, that other courts "deal with the question of substantiality im terms of dollar value of sales or profit in the abstract." Id. (citation omitted).

Other courts have relied on similar explications of "substantiality." In Velandra v. Regie Nationale des Usine Renault, 336 F.2d 292 (6th Cir, 1964), the court found that "substantial economic activities" in Michigan could be determined by a number of factors, "including the number and value of sales within the state, their ratio to the total market for like or similar products within the state, the quantity or value of the [company's] production, the percentage of the total output sold within the state ...."Id. at 296; see also Stephenson v. Duriron Co., 401 P.2d 423, 429 (Alaska 1965) (holding that "substantial volume" is not the only method used to measure a company's business presence in a state partly because "when compared with the total market demands of a fiedgling economy for specialized industrial products, it is quite likely that [the company] would be found to have been supplying a substantial portion of the total needs of the market ....").

Although these cases arise out of a different context, they show that courts have adopted a flexible approach to determine whether a company's presence is "substantial" and ways im which this might be measured. I would advocate an approach that is similarly fiexible on this point, as determined by the state at issue.

210. Allen, 410 N.Y.S.2d at 709.

211. The evidence would be presented to the relevant administrative agencies that make traderelated determinations. In the United States, they would be the International Trade Commission and the International Trade Admimistration, which is an agency in the Department of Commerce. The individual countries will decide which factors are deeined more determinative or more inportant than others. 
participation would produce evidence of its activities in the national economy, from production and assembly to servicing and promotion, or research, development, and design. As I explain in my discussion of part two of the test below, for the purpose of the proposal, the issue is a comparative one, the degree of a company's participation as measured against the duties and charges it owes.

A corporation with a substantial degree of participation in the U.S. economy, for example, is one that has a substantial proportion of its principal assets or operational facilities in the geographic territory of the United States. The assumption here is that the physical location of a corporation's assets as well as linkages forged with other local businesses may provide some measure of the extent to which benefits granted by the state to that corporation may produce direct or secondary benefits for the state itself. Therefore, to the extent that it is an accurate refiection or indicator of a corporation's substantial participation in a national economy, the location of a corporation's assets is an important consideration in the determination of corporate national identity.

U.S. subsidiaries and affiliates ${ }^{212}$ of international companies are significant participants in the U.S. economy, measured by standard factors such as employment in the United States, ${ }^{213}$ reinvestment of earnings, ${ }^{214}$ sales in the United States, ${ }^{215}$ investment in infrastructure such as plants and equipment, ${ }^{216}$ research and development, ${ }^{217}$ and exports. ${ }^{218}$ In 1997, the assets of U.S. subsidiaries of foreign companies reached $\$ 3$ trillion.

212. U.S. affiliates are firms located in the United States, with investment of $10 \%$ or more by a single or juridical person who is a national of another country. U.S. INT'L TRADE COMM., Examination of U.S. Inbound and Outbound Direct Investment, Pub. No. 3383, 4-1 (2001) [hereinafter INBOUND AND OUTBOUND DIRECT INVESTMENT].

213. Unless otherwise specified, figures discussed in this paragraph are from the Organization for International 1nvestment, Employment at U.S. Subsidiaries: The National Picture, available at http://www.ofii.org/facts_figures/national_picture.cfm (last visited Jan. 31, 2002) (on file with author). These U.S. affiliates created 20,000 new jobs in 1997, with expansions of existing U.S. subsidiary operations adding another 149,600 . On average, expansions of existing U.S. subsidiary operations have added 105,000 new jobs per year over the past five years. Among the NAFTA countries alone, foreignowned U.S. affiliates of NAFTA partners employed 628,300 U.S. workers in 1997, a figure that represents $12.2 \%$ of all U.S. workers employed by U.S. affiliates of foreign firms. INBOUND AND OUTBOUND DIRECT INVESTMENT, supra note 212, at 4-8 \& 4-9.

214. In terms of reinvestment of earnings in the United States, U.S. subsidiaries of foreign companies have reinvested an average of $35 \%$ of their earnings in the years 1991 to 1996 , and $49 \%$ in 1997.

215. Affiliates of parent companies based in seven countries (Japan, the U.K., Germany, Canada, France, the Netherlands, and Switzerland) accounted for $82 \%$ of total 1997 sales by U.S. affiliates. Japan's U.S. affiliates accounted for more than one-fourth of total foreign-owned firms' sales, or $\$ 446.4$ billion in 1997. Britain's U.S. affiliates' sales constituted $\$ 258.8$ billion; Germany's were $\$ 194.5$ billion. INBOUND AND OUTBOUND DiRECT INVESTMENT, supra note 212, at 4-13 to 4-16.

216. Fignres for 1997 show that they spent $\$ 100.8$ billion on plants and equipment.

217. Fignres for 1997 show expenditures of $\$ 19.7$ billion devoted to research and development. These companies employed more than 115,700 scientists, engineers, and technicians in their U.S. research facilities. 
Take as an example the automobile industry in the United States: If defined by reference to nationality of ownership or control, the U.S. automobile industry would be comprised of the so-called Big Three-Ford, General Motors, and Chrysler, although as a result of the latter's merger with the German-based Daimler-Benz, Chrysler could be excluded. ${ }^{219}$ But all relevant data demonstrate that U.S. affiliates of foreign-origin automakers make significant contributions to the U.S. economy, whether in the areas of employment, ${ }^{220}$ investment in production facilities, ${ }^{221}$ employment compensation, or purchases of U.S. parts, components, and materials. ${ }^{22}$ Even excluding Daimler-Chrysler, these U.S. affiliates of foreign-origin manufacturers participate substantially in the U.S. domestic economy through design, research and development, marketing, sales, distribution, and innovation through the introduction of new management techniques and technologies. ${ }^{223}$

218. Figures for 1997 show that U.S. affiliates accounted for $20 \%$ of all U.S. exports.

219. William J. Holstein, Chrysler's New Identity Crisis, U.S. NEws \& WoRLD REP., Oct. 26, 1998, at 50. This association had also expelled foreign-owned U.S. manufacturers, such as Honda, in 1992. John Maggs, Ford and GM to Chrysler: Drop Dead, NAT'L J., Oct. 3, 1998, at 2334; David Mastio, Chrysler Loses Clout with Big 3 Groups, Detrort News, May 8, 1998, at B3.

220. A 1998 study by the University of Michigan Transportation Research Institute found that the international automobile sector in the United States made significant contributions to the U.S. domestic economy for 1996, creating 402,700 jobs termed "direct employment" (manufacturing and dealer activities) combined with spin-off employment of an additional 869,600 jobs for a total of approximately 1.3 million jobs in the private sector. UNIVERSITY OF MiCHIGAN TRANSPORTation Research lNStitute et al., The Contribution of the International Auto Sector to the U.S. ECONOMY, fig.ES.1, at 14 (1998), available at http://www.osat.umich.edu/economic.html (last visited Feb. 15, 2002).

221. The U.S. affiliates have invested $\$ 12.3$ bilion in their U.S. production plants since 1982. Id. at 4 .

222. The figures for 1996 alone are an estimated $\$ 43.2$ billion in employee compensation and purchases, with $58 \%$ being purchases of U.S.-produced parts, components, and materials. Id. at 5 . This is in stark contrast to the situation in the $1980 \mathrm{~s}$, when sales by the transplants in the United States consisted almost exclusively of imports. Id. at 3 .

223. Id. at 9-12. The continued use of ownership and control as nationality criteria has had unfortunate consequences in nontrade-related areas as well, for example, U.S.-funded research initiatives. Despite their participation in the U.S. economy, anachronistic notions of "nationality" exclude foreign-origin U.S. affiliates from the Partnership for a New Generation of Vehicles ("PNGV"), a collaborative research and development program between the federal government and the U.S. "doinestic" automobile industry, represented by the United States Council for Automotive Research ("USCAR"), to develop technologically advanced, low-fuel, low-emission cars. Maggs, supra note 219. See also United States Council for Automotive Research, http://www.uscar.org (last visited Jan. 31, 2002), self-described as the umbrella organization of Daimler Chrysler, Ford, and General Motors. Ford and GM have raised questions about Chrysler's nationality upon its merger with Daimler, suggesting that Chrysler should be expelled from the U.S. auto partnership. Maggs, supra note 219. Chrysler presents itself as having dual status: "We see ourselves as a transnational company with very, very strong and deep roots in the United States and Europe, especially Germany," said Chrysler's chief lobbyist in the United States. Chrysler has, at least for now, been (correctly) allowed to remain. See Holstein, supra note 219; United States Council for Automotive Research, http://www.uscar.org. Yet, foreign-origin automakers, which do participate in critical ways in the U.S. economy, continue to be barred. Honda, for example, as the leading U.S. automobile exporter, claims the United States as its largest market, where it sells more cars than in Japan. What Is a U.S. Company Hearings, supra note 
The central point of my argument is that any company that participates substantially in the economy of any given state should be considered a domestic company of that state. For countries at a high level of economic development such as the United States, the participation that may be valued more may be that which furthers the development of the high-value, intellectual property-oriented economy, that is, research and development (whereas for poorer countries, participation in the form of light or intermediate manufacturing and assembly may be highly valued). Supporters of U.S.-owned or -controlled companies incorrectly assume that only American companies, despite the internationalization of production and investment, are likely to engage in secondary activities that are beneficial to the U.S. economy, which is not to say that U.S. companies no longer are significant participants. ${ }^{24}$ Certainly if U.S.-origin companies remain substantial participants in the U.S. economy, then they should remain U.S. companies and enjoy the attendant benefits of corporate nationality. But eligibility for and standing under the applicable laws should be defined in a way that focuses on operational indicators such as actual participation in the domestic economy. Indeed, this requirement of actual participation is a key component of the suggested test precisely because it combines the territorial component of the nationalist approach with the trade liberalizing tendency of the internationalist one.

\section{b. Socioeconomic Participation}

Under this part of the proposed domestic participation test, a corporation demonstrates its socioeconomic commitment to the state whose trade laws it hopes to enjoy through its participation in activities that contribute meaningfully to the developmental needs of that state. There is often an overlap between social and economic benefits that go toward meeting a state's developmental needs. Many countries, for example, have foreign investment laws that require the relevant authorities to evaluate the benefits

129, at 35 . The decision to exclude foreign-origin companies has also been criticized by The National Academy of Sciences as needlessly excluding the very companies that have done cutting-edge research on safety and environmental technology. Japanese automakers were the first to use multivalve engines and fuel injection which reduce emissions and increase mileage and power; Volvo introduced the first side-impact airbags; the Chevrolet/Geo Metro, made by Suzuki, was the highest-mileage car made and sold in the United States. Robert Manor, Driving Toward the Supercar, ST. Lours Post-DiSPaTCH, Sept. 18, 1994, at E1; Maggs, supra note 219. In this respect, the European approach is the more inclusive and better one, as Ford and General Motors, for example, have been allowed to participate in the Eurocar research alliance. Maggs, supra note 219; Neil MacDonald \& Bill Loveless, Execs Discuss Possible Merger of U.S., Foreign Auto Research, Fed. TECH. ReP., Apr. 22, 1999, at 3 (discussing possible collaboration among USCAR and EUCAR and Japan's JCAR projects).

224. Indeed, Department of Commerce 1991 statistics show that U.S.-based operations account for $75 \%$ of the $\$ 6.9$ trillion in total assets held by U.S. companies and that U.S.-owned parent companies spend $\$ 21$ on research and development in the United States for every $\$ 1000$ in sales. Daniel Burton, Jr. et al., supra note 78 , at 33 . 
of the proposed investment ${ }^{225}$ by reference either to the country's written investment laws or a discretionary "operational code."226 The relevant agency ${ }^{227}$ considers a whole spectrum of social and economic factors, including location of the proposed business, its impact on national culture, ${ }^{228}$ employment, training, research and development, competition in the domestic industry, "new training and job opportunities," effect on the country's balance of payments, and the nation's ability to participate in the world market. ${ }^{229}$ The preference mix is likely to vary among countries and is likely to be made by reference to guidelines established by that country, either applicable across the board, or applicable to particular industries as determined by the country. 230

Different states at different levels of development and with different national value systems will have different socioeconomic priorities. As is already the case in practice in the area of investment, it is up to the designated authorities in those states to make the necessary evaluations. There are no bright-line rules that will dictate the outcome of competing values, policy considerations, and potential tradeoffs. ${ }^{231} \mathrm{~A}$ nuclear power plant may be less valuable to one state than an oil-drilling project, and the construction of bridges may be less important than a project designed to transform salt water into fresh water. Similarly, a foreign joint venture that einploys 12,000 people has more value than just the payment of wages if the venture is in a small country that suffers from high unemployment and surplus rural labor. Conversely, the project's value in social terms would probably be

225. FoLSOM ET AL., supra note 172, at 776-81. These authorities with investment review power make determinations on a case-by-case basis. The decisions are made by reference to the written law and also by reference to unwritten understandings of what type of investment is particularly beneficial to the economic development of the country. Foreign investment review is not limited to developing countries. Canada, for example, has had a series of laws to review foreign investment. A Canadian Foreign lnvestment Review Agency was created to determine whether investment will benefit Canada and whether the investment will have certain effects on "productivity, efficiency, innovation, technological development, competition, culture and rule in world markets." Id. at 780 . To encourage investment, the current Investment Canada Act has raised the threshold, in dollar terms, of acquisitions that would trigger review. Id. at 780-81.

226. Id. at 785 .

227. See supra note 211.

228. Canada, for example, reserves the explicit right to review foreign investment in certain designated cultural industries. FoLSOM ET AL., supra note 172, at 780 n.4.

229. II. at 780 .

230. The evaluation of participation should allow reassessinent by the country should a company's participation significantly change, either annually or biannually. The frequency with which this is accomplished would depend on how often the individual country already collects relevant data.

231. One might predict that certain developing countries that place a greater value on economic development than other values would favor the construction of new plants in their territories even if this may cause environmental problems. China, for example, has forged ahead with the construction of the Three Gorges Dam despite widespread international concern that the dam would inflict serious damage to the surronnding region and to the living creatures in the Yangtze River. Andrea Wang, China's Energy' Policy and Competing International Environmental Pressures, 2000 CoLO. J. INT'L ENvTL. L. \& POL'Y 271, 277-78 (2000). 
small compared to its economic benefits if it were undertaken in a developed country such as the United States during a period of relatively high employment.

The socioeconomic component of a company's participation will be evaluated "subjectively," by reference to the particular national or democratic framework that informs public decision making, but this evaluation will also be performed in conjunction with more "objective" criteria. ${ }^{232}$ As discussed above, the geographic location of a corporation's operational or principal assets is an important indicator of whether or not a corporation meets the "substantial" participation test. In making a determination of corporate nationality, a state may opt to give greater weight to a company's participation that is likely to be "locked in" a state's territory, investment with "sunk costs,"233 than participation that is likely to be transient. Such "locked-in" types of participation include investment in immobile industryspecific assets such as automobile manufacturing and production facilities that are more difficult or costly for the investor to abandon, relocate, or convert to other use; investment in firm-specific assets such as the development of brand-name products, which requires long-term investment before brand-name recognition is achieved; ${ }^{234}$ large-scale investment in industries with low profit margins; investment in operational facilities and equipment with long life spans rather than those that quickly become obsolete; ${ }^{235}$ and investment in facilities that require specialized, high-skill workers available in only select markets, as opposed to investment in simple assembly operations that are easier to duplicate and require widely available low-skill, low-wage workers. ${ }^{236}$ In summary, to the extent that "locked-in" investment is an important consideration in determining

232. Generally speaking, the objective factors to be included in the proposed domestic participation test are already considered in the United States by the International Trade Commission ("ITC"), and the economic data needed to make a determination of a company's domestic participation would already be available. See In re Certain Airtight Cast Iron Stoves, U.S.ITC Pub. 1126, Inv. No. 337-TA-69 (Dec. 1980) (finding that U.S. subsidiary of a Norwegian stove manufacturer was an industry in the United States for purposes of eligibility to press certain trade claims, because the ITC determined that the company's U.S. activities consisted of testing, repairing the imported stoves, shipping, servicing, and advertising); In re Certain Miniature, Battery Operated, All Terrain, Wheeled Vehicles, USITC Pub. No. 1300, Inv. No. 337-TA-122 (Oct. 1982) (establishing that limited qualitycontrol and packaging activities, sales, and promotional activities, such as distribution and advertising, were not sufficient to make the company a member of the domestic industry entitled to certain domestic trade protection); Heavyweight Motorcycles and Engines and Power Train Subassemblies Therefore, USITC Pub. 1342, Inv. No. TA-201-47 (Feb. 1983) (finding that in a Section 201 action U.S.-based subsidiaries of Japanese motorcycle producers, Honda and Kawasaki, were domestic producers of heavy weight motorcycles because economic data showed that a substantial portion of the value of their motorcycles produced in Japan was added in the U.S).

233. Robert S. Pindyck, Irreversibility, Uncertainty, and Investment, 29 J. EcoN. LIT. 1110,1111

(1991).

234. Id.

235. MUltinationals AND THE NATIONAL INTERest, supra note 140 , at 24.

236. Gereffi, supra note 139 , at 84 . 
corporate nationality for certain trade and investment benefits, it is a factor that may be evaluated in terms of dollars and factored into the total determination. $^{237}$

\section{Step Two: The Participation Offset Right}

Under step one, the domestic participation test is applied to resolve the issue of corporate nationality. If a company is not considered domestic under step one, it is "economically foreign," thus subjecting its imports (if any) to all trade-protective measures applicable under the current trade laws. ${ }^{238}$ If, however, a company qualifies as domestic under step one, like all domestic companies under current law, it would have standing to invoke the benefits afforded by existing trade laws. Additionally, and especially significant to the balance this proposal aims to strike between nationalist impulses and internationalist ambitions, the domestic company would be granted a participation offset right: it would have the right, not available under any current U.S. trade laws, to offset any tariffs or charges it owes (if it imports) against the participation it has invested in the domestic economy, if its participation outweighs the amount of tariffs owed.

Under the offset right, the company may have the following types of duties offset. The domestic government would waive any import duties such as tariffs that the company would owe under current rules-of-origin laws ${ }^{239}$ if it imports certain products into the Umited States-if the amount owed is less than the amount it contributes under the first part of the socioeconomic participation test. If the company is also involved in other importing activities that are subject to additional tariffs or charges pursuant

237. There is growing acceptance of the notion that a corporation's nationality should be made by reference to the company's participation in the United States, rather than the nationality of its owners or the place of incorporation, at least in the area of high-technology initiatives. In the Federal Technology Transfer Act of 1986, 15 U.S.C. $\$ 3710$ (1994), Congress included statutory guidelines on companies eligible to participate in cooperative R\&D agreements ("CRADAS") established and referred to in the Stevenson-Wydler Technology Innovation Act of 1980, 15 U.S.C. $\$ \$ 3701-3717$ (1994). As amended, the relevant CRADA provisions provide that eligible participants are coinpanies "located in the United States which agree that products... made under the... agreement... will be manufactured substantially in the United States ..." 15 U.S.C. $\$ 3710 \mathrm{a}(\mathrm{c})(4)(B)$ (1994). There is also a provision requiring that firms "subject to the control of a foreign company" be excluded from CRADA if their home countries do not offer reciprocal opportunities to U.S. persons. Id. See also William H. Lash, III, The Decline of the Nation State in International Trade and Investment, 18 CARDozo L. REv. 1011, 1020 (1996). For a critique of the control criterion, see supra notes 190-98. For a critique of these programs, see Mark A. Warner \& Alan M. Rugman, Competitiveness: An Emerging Strategy of Discrimination in U.S. Antitrust and R\&D Policy?, 25 LAW \& POL'Y INT'L Bus. 945 (1994).

238. To use the United States as an example, if the company inports merchandise that is deenied to have violated the antidumping laws, it would pay a dumping duty, as currently required; or if the company imports merchandise into the United States at such increased quantities that the imports cause serious injury to domestic industry producing like products, increased import duties or quotas pursuant to Section 201 could be imposed to provide relief.

239. See infra notes $242-48$ for a discussion of rules used to determine the national origin of a product. In Part III.B, I propose a way to rethink rules of origin. 
to Section $201,{ }^{240}$ or any activities that are deemed in violation of the antidumping laws or other trade laws, ${ }^{241}$ it may offset these additional amounts, again, to the extent of the value of its domestic participation.

As a general matter, the amount assessed on an imported product, either as normal import duties or as a result of a Section 201, antidumping, or other trade proceeding, currently depends partly on its country of origin. In the United States, imports are subject to the Harmonized Tariff Schedule of the United States, ${ }^{242}$ which consists of a complex set of tariff rates depending on the type and value of imported goods and the origin of the goods. Imports may be subject to either the preferential rules of origin or general, nonpreferential rules of origin. Preferential rules of origin

240. Where a U.S. company conducts assembly, manufacturing, or partial manufacturing of certain products outside the United States and then imports those products into the United States, several issues need to be assessed. For example, will those products that are considered imports for customs purposes also be considered imports for other purposes, such as under a Section 201 investigation? See supra note 202. See generally Certain Cameras, USITC Pub. 2315, Inv. No. TA-20I-62 (Sept. 1990). In the Certain Cameras case, in an action by petitioner Keystone Camera Company asserting that increased imports of certain cameras was a substantial cause of serious injury to the domestic industry, the ITC found that imports were not a substantial cause of injury. In the process, the ITC had to determine whether or not to include within the domestic industry Kodak's production facilities of (1) 110 camera parts that are exported to Mexico for assembly and (2) its 35 mm camera parts exported to Mexico and Brazil. Kodak opposed Keystone's petition, asserting that increased imports of certain cameras are not seriously injuring domestic industry and also that all of its U.S. camera production activity should be included with the domestic industry, even if the cannera is partially manufactured and assembled abroad.

The ITC unanimously concluded that domestic production facilities relating to the $35 \mathrm{~mm}$ camera parts should not be included within the domestic industry manufacturing cameras because the foreign value added abroad is too significant. However, with respect to Kodak's 110 camera parts that are exported to Mexico for assembly, the ITC was divided. Two commissioners found that Kodak engages in sufficient domestic production activity relating to these 110 cameras and that the cameras should thus be viewed as domestic articles. By contrast, two other commissioners classified Kodak's imported 110 cameras from Mexico as imports and not as domestic products.

The point is that products manufactured or assembled outside the United States by U.S. firms might not be considered domestic articles by the ITC, in which case, they would be deemed imports causing serious injury to the domestic industry and subject to additional Section 201 adjustment relief such as increased tariffs beyond the bound tariff concessions. Under the participation offset right, if a company first qualifies as domestic under the substantial and direct participation test, its imports could be exempt from such additional tariffs imposed by the ITC.

241. For example, the same issue regarding whether to treat certain products as domestic or imported, either because they contained significant foreign content or because they were manufactured or assembled outside the United States, also arises in antidumping and countervailing duty cases. In Certain Radio Paging and Alerting Receiving Devices from Japan, USITC Pub. 1410, Inv. No. 731-TA-102, (Aug. 1983), the ITC determined that the pagers at issue, though assembled abroad and containing foreign parts, should be considered part of domestic production because there was a significant percentage of domestic value added and because the domestic activities in the United States involved a high level of technical expertise and capital investment. As domestic articles and not imports, these pagers would not be subject to antidumping duties. If, however, a product were deemed an import and subject to the imposition of antidumping duties, the duties would, under my proposal, be eligible for the participation offset right if the company at issue were deemed a domestic company under the proposed domestic participation test.

242. Enacted by Subtitle B of Title I of the Omnibus Trade and Competitiveness Act of 1988. See infra note 277. 
determine whether imports qualify for duty-free treatment under a reciprocal free trade agreement or other preferential arrangements. ${ }^{243}$ General or nonpreferential rules of origin are used to determine a product's country of origin for purposes other than the granting of tariff preferences, such as the application of duty rates to imports, antidumping or countervailing duties, country-of-origin marking, ${ }^{244}$ or the implementation of country-specific quotas and voluntary export restraints. ${ }^{245}$

Nonpreferential rules of origin are simple if complete production takes place in one country. ${ }^{246}$ But in other cases where materials, manufacturing, or assembly do not originate in one country, U.S. law looks to see where a "substantial transformation" of the materials into the finished product occurs, so that, as a result of a manufacturing process, a new and different article, having a distinctive name, character, or use, emerges. ${ }^{247}$ The substantial transformation test is used to confer origin for U.S. tariff purposes on the country where the substantial transformation takes place if nonpreferential, rather than preferential, rules of origin are involved. ${ }^{248}$

If an item is deemed the origin of a WTO-member country, it would be subject to the Most Favored Nation ("MFN") tariff rate negotiated for that product. An item made in a non-WTO country would be subject to non-MFN tariffs, under the Smoot-Hawley Tariff Act of 1929, which is prohibitively higher than MFN. If it is deemed the origin of a country with which the importing country has a preferential agreement, it would be sub-

243. Examples of preferential schemes include NAFTA, the Caribbean Basin Initiative, 19 U.S.C. $\S \S 2701-2706$ (1994), the Andean Group preferences, 19 U.S.C. $\$ \S 3201-3206$ (1994), and other nonreciprocal systems that accord preferential access to the U.S. market, such as those afforded to developing countries under the Generalized System of Preferences, 19 U.S.C. $\S \S 2461-2465$ (1994).

244. Article IX of GATT sets forth rules about country of origin marking requirements. One of the objectives of marking requirements is to inform the ultimate purchaser of the origin of the article he or she intends to purchase. See United States v. Ury, 106 F.2d 28, 29 (2d Cir. 1939).

245. N. David Palmeter, Rules of Origin or Rules of Restriction? A Commentary on a New Form of Protectionism. 11 FordHAM INT'L L.J. 1, 3 (1987).

246. See 19 U.S.C. $\$ 2518(4)$ (B) (1994). Products that fall in this category are the easy cases and include the following: live animals born and raised in a country, fish caught in a country's rivers or within its exclusive economic zone or caught on the high seas from a country's ships, products made from such aninals and fish, plant and plant products grown in one country, mineral goods extracted from its territory, and manufactured goods where all the parts are produced in one country. See Gantz, supra note 172 , at 378 .

247. 19 C.F.R. $\S 10.14($ b) (2001). For a critique of the "substantial transformation" test as applied, see infra notes 270-310.

248. Free trade agreements have their own preferential rules of origim. NAFTA, for example, has its own highly restrictive preferential rules of origin designed "to benefit regional producers of finished goods by encouraging manufacturers, particularly in Mexico, to go beyond serving as staging grounds for final production and assembly and into the nuanufacture of major parts and conponents anywhere in the North American region." Gantz, supra note 246, at 376. NAFTA adopts what is called a tariff shift rule in cases where all parts are not obtained in the region. When a change in tariff category occurs, the country where that shift takes place is the country of origin. NAFTA, supra note 172, art. 401,32 I.L.M. at 397. The NAFTA tariff shift rule is not very different from the substantial transformation approach because "under the Harmonized Tariff System, a change in tariff classification usually reflects a manufacturing process that causes the shift in tariff category." Gantz, supra note 246, at 381. 
ject to that applicable, better-than-MFN preferential rate. However, as noted, WTO member countries are allowed to suspend MFN tariff concessions and impose higher tariff rates under specified conditions if, for instance, increased quantities of imports threaten or cause serious injury to a domestic industry under Section 201 or if "unfair" trade acts, such as dumping, cause material injury to a domestic industry.

Under the proposed participation offset right, whatever duties or charges a company's imports are subject to ${ }^{249}$ as described above-whether under the rules of origin, import relief or unfair trade actions-are still "owed," except that the cumulative amounts may be offset against the company's domestic participation (if any), provided that the value of domestic participation exceeds the amounts owed. Assume that a company is domestic under the domestic participation test. Assume also that the corporate participation is calculated to be worth $\$ 100{ }^{250}$ The company could be issued a participation certificate with a face value of $\$ 100$. The participation certificate would function essentially as a "free pass," allowing this domestic company to be exempt from payment of all tariffs or duties, up to the value of its participation certificate. ${ }^{251}$ Assume further that the corporation also imports a line of component parts from Germany, and in accordance with the U.S. rules of origin, the company owes $\$ 30$ in MFN-rate tariffs. In a separate antidumping proceeding brought against it, the company is found to have sold its imports into the United States at less than fair value by $\$ 20$. The company would therefore owe a total of $\$ 50$. However, because it has been deemed a domestic company under the domestic participation test, giving it the "participation offset" right, it in fact will have to pay nothing because its participation valued at $\$ 100$ exceeds the $\$ 50$ owed. If, however, the company owed an additional $\$ 60$ because of a separate Section 201 action which caused its imported goods to be dutiable at the higher non-MFN rates, it would have to pay $\$ 10$.

249. An ancillary issue that needs to be addressed is whether or not there has to be a connection between the first step (the corporation's domestic participation) and the second step of the test (the corporation's imports against which it claims a "participation offset" right). In other words, must the imports at issue be related or connected to the company's current area of business participation? The answer should be no. Given the complex world of modem businesses, many of which produce or participate in the production of an ever-expanding line of products, and given the desire of companies to expand into new areas and new product lines, plus the necessity of making these decisions with all necessary speed, the requirement of a connection would be outdated. Thus, it would be in the state's interest to allow the company to select the particular imports that the company chooses to weigh against its own "net total" participation.

250. See supra note 232 (discussing the ITC's reliance on existing economic data to determine “domestic industry").

25I. A parallel might be made between my proposal to give domestic companies a free pass exempting them from all tariff payments up to the value of their participation and the practice adopted by many countries to exempt certain imports or investments (usually technology or high-technology products or sectors) from import taxes. See Zhaodong Jiang, China's Tax Preferences to Foreign Investment: Policy, Culture and Modern Concepts, 18 Nw. J. INT'L L. \& BUs. 549, 609 (1998). 
Faced with this scenario, a company may lower its expenditures to make up for the higher cost. For instance, it could cut its labor force in the United States, substitute higher paid employees with lower paid ones, or freeze its planned business expansion. If the cost of doing business is greater than the benefit received, the company may also opt to relocate. Alternatively, the company could avoid the added charge altogether. It could increase its doinestic participation (which would further the aim endorsed in this Article of "localizing" global companies and promoting the needs of the local without opposing the global) or give up importing and use local products as substitutes. In other words, the company would have the option of deciding whether or not to continue importing, perhaps because the imported products are indispensable, or substitute local products mstead. Equally important, it could also act to lower the tariffs owed on its imports by taking advantage of the no-duty-GSP ${ }^{252}$ preferential program and importing products from a GSP-eligible country which would enter the United States duty free. The GSP statute "represents the United States' participation in a multinational effort to encourage industrialization in lesser developed countries through international trade." ${ }^{253}$ To the extent that a company conducts its operations in a beneficiary developing country in ways that would meet certain minimum content requirements ${ }^{254}$ to qualify for duty-free treatment, it would lower its own operational costs as well as further the policy of the Uinted States to foster economic development in those countries.

The domestic participation test and the "participation offset" right strike the right balance between the national and the international because they encourage companies that may otherwise be even more globally mobile in orientation to increase their participation in a particular country's domestic econoiny. The proposed test, in essence, allows legitimate national interests to be brought back into the equation without succumbing to economic nationalism. ${ }^{255}$

252. Under international and U.S. trade rules, the generalized system of preferences ("GSP") allows rich countries to admit products from certain qualified poorer countries at a lower-than-MFN rate, without requiring reciprocity from the poor countries. Michael J. TREBILCOCK \& RoberT Howse, The Regulation OF InTERNational Trade 22 (2d ed. 1999); see also supra note 243.

253. Torrington Co. v. United States, 764 F.2d 1563, 1565 (Fed. Cir. 1985).

254. 19 U.S.C. $\$ 2463(2)$ (A)(ii) provides that duty free treatment is applicable:

If the sum of $(\mathrm{l})$ the cost or value of the materials produced in the beneficiary developing country ... plus (II) the direct costs of processing operations performed im such beneficiary developing country ... is not less than 35 percent of the appraised value of such article at the time it is entered [in the customs territory of the United States].

Id.; see also Torrington Co., 764 F.2d at 1565.

255. Only companies that qualify as domestic under the domestic participation test may exercise the participation offset right. This means that qualified domestic companies that import products may not have to pay duties on their imports. Foreign companies that import the same products would. Some interesting issues may be raised by this proposal. First, is there a national treatment problem under the GATT, Article III? General Agreement on Tariffs and Trade, Oct. 30, 1947, 61 Stat. A-11, T.I.A.S. No. 
1700, 55 U.N.T.S. 194. This agreement was incorporated into the General Agreement on Tariffs and Trade 1994 through the creation of the WTO at the Uruguay Round of Negotiations that ended in 1994. See Final Act Embodying the Results of the Uruguay Round of Multilateral Trade Negotiations, April 15, 1994, 33 I.L.M. 1125, I143. This is unlikely, because the proposal does not raise any issues of discrimination against imported goods in favor of like domestic goods. There is nothing in the proposal that suggests using internal taxes, internal charges, laws, regulations, and requirements in a way that would favor domestic products over imported products. Id. There is no inter-product competition issue raised by the proposal in any way. In fact, the proposal would treat imports the same as like domestic products, as required by the national treatınent clause in Article III, and it would treat imports from one country sinilarly as like imports from another country, so that any advantage granted by any contracting party to any product of one country would be granted to the like product of other contracting parties, as required by the most favored nation clause in GATT Article I. Id., art. I. The differential treatment is not between imported products versus like domestic products, but domestic versus foreign companies. This differential should be normatively defensible, however, because the concept of nationality under the proposed test is inclusive and broad-any company, even those deemed foreign-origin under current tests, is eligible to be a national of a country if it participates substantially in that country's economy.

Consider the following example. Canadian Car Company ("CCC") makes wire mesh for air bags in its facilities in Michigan and Toronto. It imports French Steel Rods into both Canada and the United States (assumc that neither NAFTA nor the Canada-U.S. Free Trade Agrecment is implicated). CCC Toronto might or might not be a national of Canada under the proposal; it could be if it meets the domestic participation test (but not if its connection to Canada is merely that it was incorporated there). Similarly, CCC Michigan might or might not be a national of the United States under the proposal. For this example, assume that CCC Canada is a national of Canada, and CCC Michigan a national of the United States. CCC Michigan would be able to offset duties for the French Steel Rods if the amount owed is less than the value of its participation in the United States. So would CCC Toronto be able to offset duties for French Steel Rods if the amount owed is less than the value of its participation in Canada, assuming Canada adopts the domestic participation test and offset right proposed here. The proposal contemplates adoption of the domestic participation test and offset right not just by one country, the United States, but multilaterally, as a test for determining corporate nationality that is more in keeping with the developments posed by globalization.

Second, does the participation offset implicate GATT rules on subsidies? Subsidies are for the first time defined in the WTO Agreement on Subsidies and Countervailing Measures, available at http://www.wto.org/english/docs_e/legal_e/final_e.htm (last visited Feb. 23, 2002) [hcreinafter WTO Agreement on Subsidies]. The offset might coneeivably be deemed a subsidy under Article 1.1(ii)"government revenue that is otherwise due is foregone or not collected." The other definitions in Article 1.1, for example, financial contribution by government or any public body where the government practice involves a direct transfer of funds (grants, loans, equity infusion, or loan guarantees) would not be applicable. But even if the offset is deemed a subsidy, it would not be a prohibited subsidy under Article 3 of the Agreement on Subsidies because the offset is not contingent in law or in fact on export performance or on the use of domestic over imported goods. The offset might be an actionable subsidy if it is deemed a specific form of government assistance to firms or industries as defined in Article 2, for example, whether the granting authority "explicitly limits access to a subsidy to certain enterprises," and if it causes injury to the domestic industry of another country, nullification or impairment of benefits to another country, or serious prejudice to the interests of another country. Id. at art 2.1(a), art. 5 .

Because the offset right is available only to domestic enterprises, one could argue that it might be considered a specific subsidy granted only to certain enterprises. However, as noted above, the very conccpt of nationality proposed in this Article is designed to broaden the traditional tests of nationality to be more inclusive. Thus, although the offset right is available only to domestic enterprises, under the new test, any company, regardless of its place of incorporation, seat of management, or nationality of shareholders, may be deemed a domestic enterprise. Given this broad and general reconceptualization of the "nationality" standard, the offset right should in fact not be regarded as a specific subsidy. Indeed, this Article suggests that, to the extent that many of the concerns expressed in the GATT were rooted in an old framework of "nationality," that is, "domestic" versus "foreigu," they may no longer 
There are a few other observations to be made. Although the test is formulated to adapt notions of nationality to a world in which corporations and products are genuinely international, its analysis does continue to work from a premise that nationality remains consequential - at least as reflected in certain trade provisions such as the antidumping law and other laws discussed above. I have argued elsewhere against the antidumping laws as a vestige of protectionism incorrectly premised on the assumption that protecting domestic firms from acts of foreign firms is a prerequisite to protecting the health of the national economy. ${ }^{256}$ Certainly, in a world of perfect free trade, antidumping laws and tariffs derived from rules of origin in general should be increasingly less significant. And certamly, corporate nationality and product identity among different countries may at some point be as relevant as they are among the states within the United States, that is, not much at all. In fact, one possible outcome of the mcreased ownership of domestically based facilities by affiliates of foreign companies as well as the increased reliance of domestic companies on foreign production and foreign outsourcing may be to discourage domestic companies from initiating antidumping proceedings against foreign producers with whom they have a preexisting relationship through equity holding or contractual dealings. ${ }^{257}$

We have already seen some instances of such conduct. For example, when Ceramic Process Systems Corporation of Massachusetts, a U.S. company that manufactures ceramic parts for computer and advanced weapons systems, petitioned the Commerce Department for trade protective measures against Kyocera, a Japanese company that dominates the industry, it was successfully opposed by established players of U.S. industry, such as the American Semiconductor Industry Association, I.B.M., and the Aerospace Industries Association, either because they were eager to avert a trade conflict or because they had their own significant relationship with the Japanese company. ${ }^{258}$ From 1989 to 199I, plans by the Bush administration to impose tariffs on displays for laptop computers had to be dropped after encountering opposition from Apple Computer and other U.S. customers that relied on Japanese parts for their products. ${ }^{259}$ Similarly, Toyota Motor Corporation used its 119 American suppliers as leverage to oppose import quotas or higher tariffs on minivans, urging the U.S. suppli-

be applicable in the same way, should the "nationality" framework be expanded in the direction 1 an proposing.

256. Cao, supra note 206, at 219-22.

257. See, e.g., 2 The GatT URuguay Round: A Negotiating History (1986-1992), at 1582 (Terence P. Stewart ed., 1993) ("Because of the inany industries that are characterized by significant foreign ownership, it is quite common in the U.S. for trade associations to be unable to inuster authorization for the filing of antidumping petitions.").

258. Stephen Engelberg \& Martin Tolchin, Foreigners Find New Ally in U.S. Industry, N.Y. Times, Nov. 2, 1993, at Al.

259. Id. 
ers to engage in a concerted letter-writing campaign expressing disapproval of the Clinton Administration's plan to engage in protective measures against Japanese automakers. ${ }^{260}$

Thus, as a practical matter, the modern realities of international interdependence may mean that trade protective laws for "domestic" companies seeking relief from import competition will become less used and less useful. Nonetheless, assuming that there are still laws within the WTO that work from a distinction between the "home" and the "foreign," the proposal is designed to encourage individual countries within the existing trading system to accommodate, through their trade laws, both their nationalist and internationalist ambitions.

\section{B. Reforming Product Nationality: A New Rule of Origin Framework}

Unless the international trade system eliminates rules of origin altogether, they remain relevant under current $l \mathrm{w}^{261}$ and under the proposed domestic participation test and its offset right. But there are real problems with rules of origin as currently understood. First, as detailed in Part II, the distinction between domestic and foreign products is no longer clear, making a rule-of-origin application increasingly indeterminate, arbitrary, and so complex that it is difficult to meet. ${ }^{262}$ The erosion of sovereignty calls into question:

260. Id.

261. See generally Silveira, supra note 172 , at 463 n.3, 473. Rules of origin are needed for preferential and nonpreferential trade purposes. Rules of origin determine which products from which countries may benefit from preferential trade agreements. They also further nonpreferential goals such as the determination of the appropriate tariff rates to be applied for Customs purposes as well as for general statistical purposes and the identification of the relevant products where antidumping or countervailing duties have been imposed. See also WTO Rules of Origin art.1(1) to 1(2), supra note 205.

262. The European Community (the "EC") has its own rules of origin, some of which are designed to grant EC preferences to certain beneficiary countries by requiring certain conditions to be met before preferences are granted. For example, the Fourth Lome Convention between the EC and the so-called African, Caribbean, and Pacific States ("ACP") require the following rules of origin before EC preferences for $\mathrm{ACP}$ fishery products can be granted:

canning does not confer origin; to have origin of the ACP States the fish must be "taken from the sea by their vessels"; to qualify as "their" (i.e. ACP) vessels, vessels must be registered in an ACP State (or an EC Member State), sail under the flag of an ACP State (or an EC Member State), must be owned at least 50 percent by nationals of an ACP State (or of an EC Member State) or by a company that has its head office in one of these states, of which the manager or managers, chairman of the board of directors or the supervisory board, and the majority of the members of such boards are nationals of an ACP State (or of an EC Member State) and of which, in addition, in the case of partnerships or limited companies, at least half the capital belongs to ACP States (or to EC Member States) or to public bodies or nationals of such states, and of which at least 50 percent of the crew, master and officers, are nationals of ACP States (or of an EC Member State).

Jacques H. J. Bourgeois, Rules of Origin: An Introduction, in RULes of ORIGIN IN INTERNATIONAL TRADE, supra note 124 , at 3.

Besides being unnecessarily complicated, those origin rules are also too stringent for beneficiary countries to meet. Additionally, as has been noted, "[i]f these rules of origin are designed to encourage 
a central notion of GATT: that all merchandise has a single nationality. Whether dealing with tariff bindings or "unfair trade" remedies, GATT rules assume (without definition or explanation) that all imports into a country have an objectively certain single national source. But the identification of this national origin is often difficult and arbitrary. ${ }^{263}$

Second, these highly complex rules and the equally complex customs regulations implementing them may also be a form of nontariff barrier impeding duty-free trade. ${ }^{264}$ Third, there are questions about their relevance to consumers in today's global economy. For example, currently, under Section 301 of the Tariff Act of 1930, "every article of foreign origin" or its container must be appropriately marked to inform the "ultinate purchaser"265 in the United States of its country of origin. ${ }^{266}$ Yet, in today's global economy, one could question whether or not the premise of the marking statute is still relevant. Do consumers care about country-of-origin labels or about brand? Setting aside the special scenario of boycotting products from countries that tolerate practices that are contrary to one's own sense of ethics, consumers in most other cases are less likely to care that Nike shoes are made in one country versus another and more likely to be concerned with whether or not the Nike shoes they own are authentic or fake. ${ }^{267}$ Fourth, the current "substantial transformation" rule, designed specifically to aid in the determination of the nationality of a product that is made of parts from many countries, is unsuited for the current postindustrial, global economy. And fifth, as I develop further below, current rules also exacerbate the distributional gap that globalization may impose on poor countries and lesser-skilled workers in rich countries.

the ACP countries into developing a fishing and fish processing industry entirely of their own, it is difficult to understand why fishing vessels may be owned by EC nationals or by EC companies." Id.

263. Ehrenhaft, supra note 7, at 231.

264. See, e.g., U.S. General Accounting OfFice, IMPLEMENTATION OF the U.S.-Canada Free TRADE AGREEMENT 28-31 (GAO/GGD-93-21, 1992).

265. Who is an "ultimate purchaser" is also a contestable issue. See, e.g., Pabrini, Inc. v. United States, 10 Ct. Int'l Trade 128 (1986); National Juice Products Ass'n v. United States, 10 Ct. Int'l Trade 48, $57-58$ (1986). Section 304 of the Tariff Act of 1930, 19 U.S.C. $\$ 1304$ (1994), requires that all imported merchandise be marked in a manner "conspicuous" to the "ultimate purchaser." An ultimate purchaser is defined in Customs regulations as "the last person in the United States who will receive the article in the form in which it was imported." 19 C.F.R. $\$ 134.1$ (WESTLAW through Sept. 4, 2001).

266. Presumably, "the primary purpose of the country-of-origin inarking statute is to 'mark the goods so that at the time of purchase the ultimate purchaser may, by knowing where the goods were produced, be able to buy or refuse to buy them, if such marking should influence his will.' (Congress, of course, had in mind a consumer preference for American made goods.)" National Juice Products Ass' $n, 10 \mathrm{Ct}$. Int'l Trade at $58 \mathrm{n} . \mathrm{I} 4$ (citation omitted).

267. See generally Raj Bhala, International Trade Law 397 (1996). On a related note, assuming that consumers do care about the country of origin of a product, current marking rules may not truly reflect the origin of a product because a product is comprised of global composites. The marking statute, in today's global economy, may have the effect of deceiving the very consumers it is supposed to inform. 
As a result, questions have been raised about whether it is possible to retain rules of origin.

In addition, with investment flows now growing at a far greater rate than trade flows, the question arises to what extent it will be practical to define the origin of goods. Furthermore, it might be questionable whether it will be of any value to do so, with growing multicountry production and the largest producers becoming international corporations through acquisitions as well as the increasing establishment of transplant factories. ${ }^{268}$

However, to the extent that rules of origin remain a part of the international economic system, ${ }^{269}$ I propose that they be reexamined in light of the global economy.

The "substantial transformation" test that is the core of rules of origin laws must be reevaluated. ${ }^{270}$ The test might once have been suitable for a nationally based industrial economic system, but is now obsolete and too narrow for a postnational, postindustrial economic system. There are two primary problems with its continuing application to the current trading system. First, the test is unable to capture the full and complex range of economic activities undertaken by skilled and lesser-skilled workers in rich and poor countries. Second, the test consequently has a detrimental impact on and is unresponsive to the needs of workers at the lower end of the skills spectrum.

The proposal for revision starts with a reexamination of the current "substantial transformation" test used in nonpreferential rules-of-origin determinations. ${ }^{271}$ Under the "substantial transformation" test, if imported merchandise is produced in two or more countries, its country of origin is the country where the last "substantial transformation" occurred. The United States, for example, could "domesticate" an imported product, that is, transform it from an "article of foreign origin" into a domestic-origin product if it is "used in the manufacture in the United States of a new

268. Kingston, supra note 124 , at 24.

269. Rules of origin remain part of the national trade laws of many countries and the Agreement on Rules of Origin is a part of WTO. See supra note 205.

270. Note that the test is retained in the WTO Agreement on Rules of Origin Article 9(b):

[R]ules of origin should provide for the country to be determined as the origim of a particular good to be either the country where the good has been wholly obtained or, when more than one country is concerned in the production of the good, the country where the last substantial transformation has been carried out.

WTO Rules of Origin, supra note 205. For a discussion of how the application of the substantial transformation test by U.S. Customs Service and U.S. courts has been "fraught with subjectivity and unpredictability," see Mark R. Sandstrom, Rules of Origin: Considerations for Investment and Trade in North America, 16 ARIz. J. 1NT'L \& COMP. L. 217, 219 (1999).

271. Although 1 focus for the most part on the "substantial transformation" test used in nonpreferential rules-of-origin inquiries, my critique is equally applicable to the other tests employed im the preferential rules-of-origin context. 
article having a new name, character, and use."272 The Supreme Court, in a later case, noted that " $[\mathrm{m}]$ anufacture implies a change, but every change is not manufacture, and yet every change $\mathrm{m}$ an article is the result of treatment, labor and manipulation. But something more is necessary .... There must be transformation; a new and different article must emerge, 'having a distinctive name, character or use."'273 The Court's language suggests an emphasis on "manufacture" and a resulting "transformation" in the Umited States of the imported item. Subsequent lower court cases have been more restrictive, requirimg "substantial transformation" plus explicit "substantial manufacturing." "274

Thus, although the question of "[w] $[\mathrm{w}$ ther a substantial transformation has occurred has depended historically upon the nature of the article emerging from a particular process ... and not on the nature of the process itself,"275 the underlying process is a crucial factor in a substantial transformation inquiry. Processing or manufacturing is generally considered to be the activity that produces the requisite substantial transformation. ${ }^{276}$ The

272. United States v. Gibson-Thomson Co., 27 C.C.P.A. 267, 273 (1940).

273. Anheuser-Busch Brewing Ass'n v. United States, 207 U.S. 556, 562 (1907); see also Silveira, supra note 172, at 415 . The basic issue is "whether the 'change' (manufacturing or processing) is of such a substantial nature to justify the conclusion that the article is a product of the country where such change took place." Id. at 416. A change in "name," for example, from "fresh broccoli" to "frozen broccoli" might not confer origin, whereas a change in name from "peanuts" to "peanut butter" may. Id. A change in the "character" of a product usually involves a change in its chemical composition. Mere "finishing" processes such as painting, cleaning, or polishing, may not be a sufficient change in the product's character. A change in "use" may occur "if the process of manufacturing transforms the product from one that is suitable for one use to one applicable for another use or for multiple uses," Silveira, supra note 172 , at 415 , for example, a change from a producer to a consumer good. Id. at 416; see also Joseph A. LaNasa III, Rules of Origin and the Uruguay Round's Effectiveness in Harmonizing and Regulating Them, 90 AM. J. INT'L L. 625, 629 (1996).

274. Uniroyal, Inc. v. United States, 542 F. Supp. 1026, 1029-30 (1982) (finding that footwear uppers, essentially complete shoes without soles, were not substantially transformed by the addition of out soles because the uppers undervent no physical change and because the process of attaching the out soles was less time consuming and costly than that of producing the uppers). In 1985, the Treasury Department issued regulations requiring that "[a] textile or textile product will be considered to have undergone a substantial transformation if it has been transformed by means of substantial manufacturing or processing operations into a new and different article of commerce." 19 C.F.R. $\S 12.130(\mathrm{~b})$.

275. Palmeter, supra note 245 , at 24.

276. See Midwood Indus., Inc. v. United States, 64 Cust. Ct. 499, 507 (1970) (finding that "the end result of the manufacturing processes to which the imported articles are subjected ... is the transformation of such imported articles into different articles having a new name, character and use"); see also Palmeter, supra note 245, at 25-26 (describing the decision in Uniroyal, Inc. v. United States by the Court of International Trade, 542 F. Supp. 1026 (1982)), supra note 274, as "providing the rationale for a new and more restrictive test: 'substantial transformation' plus 'substantial manufacturing."' Palmeter, supra note 245, at 25; Mark Loftin, Flavell v. Canada: Rethinking Canada's Domestic Import Tariff Policy, 6 Sw. J.L. \& TRADE AM. 385, 403 (1999) ("'Substantial transformation' occurs when, as a result of manufacturing processes, a new and different article emerges ... which is different from that originally possessed by the articles or material before being subject to the manufacturing process."). 
major trading countries, the United States included, use three criteria to determine whether a substantial transformation has occurred: change in tariff heading, ${ }^{277}$ processing, ${ }^{278}$ and value-added operations. ${ }^{279}$ All three criteria are themselves linked in turn to an inquiry into the underlying manufacturing or processing operations. ${ }^{280}$ As a policy matter, the "substantial transformation" test is designed to cause importers to perform value-added activities in the country where the activities are to be performed, to take an act of "manufacturing" or processing in that country of

In many ways, the emphasis on manufacturing may be viewed as a proxy for some other concern: that the origin-conferring activity involves a process that requires a certain degree of skill, a certain amount of time to complete, and is not too simple. See infra notes 286-94 for a discussion of how the WTO Technical Committee on Rules of Origin attempts to address these concerns. See also infra note 285.

277. The "substantial transformation" test does not provide guidance for what constitutes "substantial." Does the transformation of copper into copper wire constitute "substantial transformation"? Under the tariff shift approach, a transformation may be substantial if it results in a change in the Harmonized Tariff System classification of the good. A change in the product's origin is deemed to "take place in the country where, as a result of manufacturing or other processing, the tariff classification of the article changes from one category to another." Silveira, supra note 172, at 417. Thus, if copper is classified in one tariff heading category and wire in another, the transformation from copper to copper wire, resulting in a change in tariff heading (or as it is also referred to, a tariff shift) might be "substantial." However, if "[m]inor features of processing, such as simple assembly . . bring about a change in the tariff category, ... a change of origin will not be acknowledged because the tariff change was not decisive." Id. at 417.

The Change in Tariff Heading rule relies on the Harmonized Tariff System. The Harmonized System groups goods in twenty-one sections, ninety-six chapters, which are established by industrial sector, and I,241 headings, with additional subheadings. The headings are important for tariff classification and origin purposes. Headings are placed within a chapter in the order based on the degree of processing, and the heading number increases as a product is further processed. A "product obtained is considered to have undergone sufficient manufacturing or processing if it falls under a heading of a systematic goods nomenclature different from the headings applicable to each of the materials utilized." International Convention on the Simplification and Harmonization of Customs Procedures, Annex Concerning Rules of Origin, May I8, 1973, annex D.I, S. Treaty Doc. No. 97-23; see also Hironori Asakura, The Harmonized System and Rules of Origin, 27 J. WorLd TRADE 5 (1993). Again, note the emphasis on processing or manufacturing embodied in the tariff-shift approach.

278. Substantial transformation can also be determined by reference to whether a product has undergone certain processing operations in a country. See N. David Palmeter, Rules of Origin in the United States, in Rules of Origin IN INTERnational TRADE, supra note 124, at 29; Michael P. Maxwell, Formulating Rules of Origin for Imported Merchandise: Transforming the Substantial Transformation Test, 23 GEo. WASH. J. INT'L L. \& ECON. 669, 670 (I990).

279. Under the value-added criterion, a good is deemed the origin of the most recent exporting country where a specified percentage of value was added to the good in that country. See Silveira, supra note 172, at 418 ("Under this procedure, one must consider the extent of the manufacturing or processing undergone in a country based on the value it adds to the goods. When this added value equals or exceeds the specified percentage, the goods acquire 'origin' in the country where the manufacturing or processing was carried out."). For example, the U.S. GSP program adheres to a $35 \%$ value-added test, I9 U.S.C. $\S \S 246 I-2465$ (1994), as does the U.S. Caribbean Basin Initiative program, 19 U.S.C. $\$ \S 270 I-2706$ (1994). In the same way that a tariff shift may occur through a minor process, see supra note 277 , "substantial transformation" is possible by means of a minor process as well. This explains the requirement in the GSP scheme that there be "both a substantial transformation and a contribution of at least $35 \%$ to the appraised value of the new and different article." Palmeter, supra note 245 , at $24-25$.

280. See supra notes $277-79$. 
sufficient significance to transform the imported article into a domestic article, in effect increasing the "local content" of a product. Aside from the political interests underlying a particular rule of origin, the problem with the "substantial transformation" rule generally is that while it might have been appropriate for an industrial, manufacturing-based economy, it is no longer suitable for today's postindustrial, global economy. If products are more or less composites that are conceived, designed, engineered, manufactured or assembled in more than one national jurisdiction:

What are the interests our international agreements and domestic laws ought to protect in these cases? Is the last important step in completing the product as imported more significant than the first idea? Is the accident of 'high value' added in one operation more important to national interests than a less expensive, but, perhaps, more innovative step? ${ }^{281}$

Although the internationalist project has aimed to contain or discipline nationalist impulses by instituting a set of universal rules to minimize the influence of politics on the international economic system, ${ }^{282}$ rules of origin generally remain imtensely political and reflect intensely nationalist objectives. They are not just about technical or technocratic considerations, but rather are a reflection of political and policy preferences. "The inescapable fact is that rules of origin are tools of discrimination. They have no other purpose. They are used to implement national and international laws that confer special benefits on goods of some countries and special penalties on goods of other countries." 283 The remainder of the Article looks at how these politicized interests should be spread if one is concerned about the emergence of the new knowledge economy and the distributional impact of global free trade on national economies. How should rules of origin be revised both to reflect the postindustrial economy and to alleviate globalization's impact on different groups in the international economic system?

As the preceding discussion reveals, the substantial transformation rule as currently interpreted is inappropriate because it requires a product to be transformed by acts that are essentially process or manufacturingbased. ${ }^{284}$ Thus, it tends to result in the exclusion of some other form of "transformation," for example, one that involves labor-intensive activities such as assembly or simple processing operations that would benefit both developing countries with abundant unskilled labor and high-volume, bluecollar workers in developed countries. ${ }^{285}$ It also excludes acts that are not

281. Ehrenhaft, supra note 7, at 232.

282. See supra notes $72-73,75-76,85$.

283. Simpson, supra note 172 , at 40 .

284. See supra notes $272-80$ and infra notes $286-94$.

285. For example, although the Report by the Chairman of the Committee on Rules of Origin, see supra note 205 , states that assembly could confer origin, it also notes that "assembly cannot be always origin-conferring." Thus the real question is to identify the threshold of the assembly work, over which 
industrial or manufacturing but do in fact benefit the local economy, for example, acts that further the development of a service industry, such as after-sales servicing and technical support. If those acts are not considered acts that "substantially transform" the product, then the performance of those acts in certain countries would have no impact on national origin determination.

Current efforts by a WTO committee to harmonize rules of origin in the Agreement on Rules of Origin remain unresolved because of disagreements about which types of activities qualify as origin conferring. Indeed, many of the contested questions center around whether the activity at issue or the skill level required to perform certain operations is sufficiently substantial and transforming. Included among the list of disagreements over which activities may constitute "substantial transformation": in the agricultural products and fish category, the slaughtering of animals, ${ }^{286}$ drying of fish, fish roes, and other fish products; ${ }^{287}$ smoking of meat; ${ }^{288}$ obtaining of fish fillets; ${ }^{289}$ obtaining of coffee creamer; ${ }^{290}$ and producing wine from

assembly can be considered as "substantial transformation." The Technical Committee was established to harmonize rules of origin among Member States, such as developing uniform understandings of substantial transformation. WTO Rules of Origin, art. 9(1), 9(2)(i) \& (ii), supra note 205. In considering the criteria for substantial transformation, the Committee will rely on the change in tariff classification method and, where necessary, the value-added methods. Id. at art. $9(2)$ (c)(ii).

Although the work was scheduled to be completed by July 1998, to date, it is not yet finished. Committee on Rules of Origin, Report by the Chairman of the Committee on Rules of Origin to the General Council, Sept. 24, 2001, G/RO/48, No. 01-4526, at para. 3.3, available at http://docsonline.wto.org.

There is still a lack of consensus among Committee members over the type of assembly and processing operations that does or does not qualify as origin conferring. See infra notes 286-94 for a discussion of some areas of disagreement among Committee members.

286. Those who favor deeming slaughtering to be a last substantial transformation argue that products obtained are completely different from the initial products in all respects: the products arising out of slaughtering are for human or animal consumption, whereas live animals cannot be used for that purpose.... Slaughtering is not restricted solely to the killing of the animal; a series of processes are necessary in order to obtain the meat or offal.

Committee on Rules of Origin, Integrated Negotiating Text for the Harmonization Work Programme, Agricultural Products and Fish, Sept. 25, 2001, G/RO/45/Add.8/Rev.1, No. 01-4529, at 4, available at http://docsonline.wto.org. Opponents argue that slaughter does not alter the quality of the meat and thus cannot constitute a last substantial transformation.

287. Those who favor counting drying of fish and fish products as substantial transformation argue that the process of drying is time-consuming and involves a change in character of the product which is significantly valued over the raw material. In this case, drying should not be regarded as merely "a process for the preservation of goods during transportation and/or storage," which would not qualify as substantial transformation. Id. at 5-6.

288. Proponents argue that smoking substantially transforms the characteristics of the meat; opponents argue that smoking is a simple process. Id. at 8 .

289. Proponents, Norway for example, argue that the production process from gutted fish to fish fillets is a comprehensive process, involving production of fillet with skin on and pin bone, splitting the fish into fillets, removal of the backbone, and skinning. Some of the processes require special machinery. Opponents argue that the process is simple and does not involve transformation of the fisb. Id. at 13-14.

290. The transformation of skimmed milk powder, through the addition of milk fat, water emulsifiers and stabilizers, sterilization, and finally cooling, to coffee creamer should qualify for 
grapes. ${ }^{291}$ In the textiles sector, disputes have centered on the following: carding or combing of fibers in preparation for spinning, , $^{292}$ down proofing fabrics, ${ }^{293}$ or bleaching of fabrics, ${ }^{294}$ among many others.

As the examples above show, the processes that are currently disputed are those that are relatively simple and involve lower-skilled labor. Yet, those are precisely the areas in which poor countries are more likely to have a comparative advantage because of their large pool of cheap and relatively lower-skilled labor. Although rich countries grant GSP or other preferential status to qualified poor countries, the "substantial transformation" origin rules with its focus on a manufacturing-based transformation often have the effect of nullifying any benefits theoretically available under GSP. As one commentator has noted:

[T] he labor content of the production process is hardly ever sufficient to guarantee origin. The origin rules incorporated nearly always close the easiest route, that of simple assembly, as a way for management and labour of underdeveloped countries to learn the skills that will enable them to move first into component production and ultimately total manufacturing. ${ }^{295}$

If rich countries were to allow assembly and other labor-intensive activities conducted in a developing country to count in the "substantial transformation" determination, the resulting product could be deemed the product of the developing country where the "substantial transformation" occurred, which would make the product eligible for better-than-MFN treatment, attract global economic activities to those countries, and encourage the development of assembly facilities in poor countries.

substantial transformation. Opponents argue that the origin of coffee creamer should remain in the country where the liquid milk was obtamed in its natural state. Id. at 19.

291. Grapes undergo a substantial transformation when made into wine. Opponents argue that the essential character of wine is determined by the grapes and the country of origin of the wine is where the grapes were produced. Id. at 69.

292. See Committee on Rules of Origin, Integrated Negotiating Text for the Harmonization Work Programme-Textile Products and Textile Related, Sept. 25, 2001, G/RO/45/Add.1/Rev.1, No. 014530, available at http://docsonline.wto.org. Those who contend that this activity constitutes a transformation argue that the process is a substantial one and that these operations are necessary before natural fibers are suitable for spinning. Wool or animal hair must be carded and combed in preparation for spinning, which involves disentangling the fibers, removing extraneous matters, laying the fibers into wide webs, and condensing thein into slivers, which must be combed before they are converted into rovings. Other members argue that the process does not qualify as substantial transformation because it is simple.

293. Some committee nembers argue that fabric treated by down-proof fimshing (pillows and sleeping bags, for example) to ensure that feathers are retained inside the cover should be deemed substantially transformed by the physical and chemical process involved. Others contend that the process does not qualify as substantial transformation because it is only a finishing process. Id.

294. Prior to bleaching, a fabric is subjected to a number of processes, such as shearing or cropping, desizing and scouring. Bleaching, which is a controlled chemical reaction, substantially transforms dirty fabric into clean, absorbent white fabric free of impurities. Opponents argue there is not sufficient transformation involved. Id.

295. Kingston, supra note 124, at 14. 
The same reasoning applies to areas in rich countries such as the United States with displaced, lower-skilled workers in technologically superseded sectors. While it is reasonable that for richer countries, the development of a higher-skilled, technology-oriented sector is of paramount importance, this shift towards higher-skilled work has also left workers, many of whom are lower-skilled minority and immigrant workers in the high-volume sectors, economically vulnerable. ${ }^{296}$ What rules should trade law adopt to ease the transition period for workers in countries undergoing the high-volume to high-value shift, one further exacerbated by the movement to globalize production? One way to address this distributional conflict is to encourage the establishment of activities, whether it be simple assembly or more sophisticated assembly, that employ otherwise displaced U.S. workers. Again, this may be achieved by altering the "substantial transformation" rule from one that currently excludes the assembly stages of production to one that includes assembly in the determination of origin rules. ${ }^{297}$

An alternative and more expansive framework for rules of origin determination could work this way. An imported item may be "domesticated" into a domestic-origin item if its parts, though imported, are assembled in the country at issue, for example, the United States. ${ }^{298}$ In order to ensure that domestication involves more than mere perfunctory assembly, an additional requirement could be imposed, for example, mandating that the U.S. assembly facilities meet certain standards regarding investment of capital in land, buildings, and employment. Other requirements may be imposed to address any concern that allowing assembly to count in origin determination would only attract inaquiladora-type operations into the United States. For example, a requirement that assembly in the United States may be included but must be capped so that it could account for only a certain (limited) percentage of the U.S. value of an item. Similarly, including assembly in the overall origins determination might also be phased out over a period of years, during which high-volume or lesser-skilled workers may be helped by adjustment prograins such as training and job search assistance.

296. See Richard Rothstein, KeEPING Jobs in Fashion: Alternatives to the Euthanasia OF THE U.S. APPAREL INDUSTRY 1-6 (1989) (describing the impact of the decline of the U.S. apparel industry on rural women, blacks, Hispanics, and immigrant workers).

297. This suggestion still may not work effectively in First World countries like the United States because what draws global companies to perform certain economic activities in the United States is not likely to be lower-skilled, lower-wage U.S. workers. Others have favored tax-financed remedies and direct wealth transfers to these workers. See Chen, supra note 16, at 212.

298. In fact, Customs rulings already allow certain assembly operations in the United States to confer U.S. origin: assembly of mechanical equipment such as laptop computers, printed circuit boards, video display terminals for televisions, and televisions. Nomio Komuro, International Harmonisation of Rules of Origin, in THE WTO ANd INTERNATIONAL TRADE REgulation (Philip Ruttley et al. eds., 1998). 
Changing the existing "substantial transformation" rule to include postindustrial activities would also allow for more logical treatment of the postindustrial economy itself. Besides the fact that the wrong political choices currently underlie the "substantial transformation" test, the test is also better suited for the older industrial economy in so far as its focus is on the manufacturing act in the final production process. If the production process is divided into four different stages-research and development, intermediate production, final production, and marketing and distribution-origin rules founded on a "substantial transformation" criteria "have their impact on the third stage (final production).... The effect of the widespread use of substantial transformation criteria is that in products where origin is important, a bias is created towards the localization of the third stage in the production process." ${ }^{.299}$ This eliminates other possibilities from serious consideration.

In certain products it might be considered that one key component is so vital to the essential character of the final product that it should provide the key to determining origin. In such products the final production stage, no matter how complex, may be considered little more than simple assembly and thus not regarded as sufficient to determine origin. ${ }^{300}$

For example, it might be that for some products such as those that are chemically based, the fourth stage, marketing and distribution, or the first stage, research and development, constitutes a substantial proportion of the value or cost of the final product. Yet, those stages are usually not included in origin determination. ${ }^{301}$

The considerations set forth above to help guide a "substantial transformation" analysis are also applicable in preferential rules-of-origin contexts. Referring to the rules of origin in the Canada-U.S. Free Trade Agreement and the North American Free Trade Agreement, for example, commentators have remarked that "reading even one chapter of each agreement is enough to make one forget what the agreement was about, as one searches for clues to rules within rules, exceptions to exceptions, and

299. Kingston, supra note 124 , at 16.

300. Id.

301. Kingston observed:

With the rapid increase in crossborder investment flows, governments are now recognizing that the important elements in the manufacturing process in the case of high technology consumer goods seldom lie in the final production (substantial transformation) stage but rather in the R\&D stage and in the capital equipment that is employed in the production stage. It could be argued-although it would add confusion to the debate-that the country of origin of a product should be where the capital equipment for producing the product is made. There is a clear difference between increasing a country's capital stock by installing imported modern equipment and having the technological ability to produce the equipment domestically.... Despite its importance, traditional concepts of origin-such as substantial transformation-do not therefore reflect the origin of the technology.

Id. at 17 . 
bewildering cross-references." ${ }^{302}$ Under the Canada-U.S. Free Trade Agreement, for example, a good containing third-country components niay be transformed into a Canadian or U.S. product if each of the nonoriginating components is transformed in the territory of one or more of the parties through processing and assembly and if this transformation also results in a change in tariff classification. ${ }^{303}$ But where the change in tariff classification occurs from one heading to another heading within a chapter (rather than from one chapter to another), ${ }^{304}$ the good is not necessarily entitled to duty-free treatment. In most cases, such a product must meet an additional test-that $50 \%$ of the value of the product when exported from one party to the other must consist of local North American content. ${ }^{305}$ With this understanding, are Honda Civics produced in the United States, whose engines are made from U.S.-origin components and imported parts from Japan, shipped to Canada for incorporation into cars, and then shipped to the United States, North American in origin and therefore eligible for duty-free treatment by U.S. Customs?

U.S. Customs said no, partly because it refused to allow certain costs incurred in North America to count towards the determination of the North America value of the product. According to Customs, the statutory allowance of "costs directly incurred in the production of goods" applied only to direct costs, not to costs such as payments for on-site technical assistance, royalties, and production controls. ${ }^{306}$ Under the expanded framework I am proposing here, activities that are not based on manufacturing but that confer value, such as service and technical assistance and support, marketing and distribution, should be included in the determination of origin. A different result might have been produced in the high-profile U.S.-Canada automobile dispute above were we operating under such a framework.

Similar issues about which activities would count or not count towards origin determination have also arisen in the NAFTA context. In determining the North American content of a product, trade administrators must decide how nonoriginating materials should be valued in the calculation of the local content of a component. What costs could be included? Although NAFTA permits processing costs to be included, partly to allow local manufacturing to count towards local content determination, NAFTA rules also specify as nonallowable costs those costs associated with sales

302. Cantin \& Lowenfeld, supra note 5 , at 389.

303. See NAFTA, supra note 172, art. 301(2), 32 I.L.M. at 299-300; Cantin \& Lowenfeld, supra note 5 , at 377 .

304. The Harmonized Schedule classifies goods into twcnty-one sections and ninety-six chapters, with each chapter divided into headings with four-digit numerical codes, which are further subdivided into subheadings, with two additional digits. See supra note 277 .

305. See Cantin \& Lowenfeld, supra note 5, at 378.

306. Id. at 381 . 
promotion, marketing, and after-sales service ${ }^{307}$ - precisely the costs associated with activities that contribute towards a service industry.

1 propose that a different framework be adopted to consider a wider range of activities for inclusion in "domestication" determinations, particularly those that are currently left out of the manufacturing or industrial orientation that underlies the current focus. ${ }^{308}$ If they are not eliminated altogether, rules of origin, already themselves a reflection of political choices, should at least aim to address, first, the political pressure points that currently pose the most serious threat to the free trade systein and, second, the emergence of nonindustrial activities that will define the new trading economy.

The "domestic participation" test, in conjunction with the new rulesof-origm approach, would work as follows: Under the first step, the company has to establish that it is economically domestic. Assuming the company qualifies as domestic, the "participation offset" right delineated in the second step of the test would be triggered, allowing the company to balance the net total of its participation against any tariffs owed on any products it imports. The alternative sketch proposed to reform the rules of origin would then be used to guide the determination of whether the product at issue is a domestic or imported item subject to which tariff or charge. If it is an import and produced in two or more countries, the "substantial

\section{Id. at 388 .}

308. To ensure that minimal acts do not qualify for origin determination, the proposed test would exclude acts normally undertaken by a pure "middleman," such as receivership, storage, wholesale, delivery of goods, or handling directly associated with these activities. An analogy may be made with cases in the products-liability area that deal with the concept of a middleman. Under these cases, a middleman (who merely deals in goods and does nothing to alter the goods or the use of the goods) cannot be held liable in implied strict liability for selling a defective product in a sealed container. See, e.g., Sain Shainberg Co. v. Barlow, 258 So. 2d 242 (Miss. 1972). A "sealed container" means a "box, container, package, wrapping, encasement or housing of any nature that covers a product so that it would be unreasonable to expect a seller to detect or discover the existence of a dangerous or defective condition in the product." DeL. CoDE ANN. tit.18, \$ 7001(a)(3) (2001); Parker v. Ford Motor Co., 331 So. $2 \mathrm{~d} 923$ (Miss. 1976).

However, if a party undertakes to repair or rebuild a product, the party may be treated as if it were the product's manufacturer. Anderson v. Olmsted Util. Equip., Inc., 573 N.E.2d 626 (Ohio 1991). Under the doctrine, a mere retailer of a product is deemed to be a middleman, not a manufacturer, even if the retailer possesses or holds himself out as possessing special knowledge with regard to the product. Coyle v. Richardson-Merrell, Inc., 584 A.2d 1383 (Pa. 1991). Furthermore, even the right to exercise supervision over the manufacturing process does not turn a middleman into a manufacturer. See, e.g., CAL. Civ. CODE $\$ 3434$ (West 1997).

For the purposes of international trade, the definition provided by the "sealed-container" doctrine cases is helpful because the doctrine offers a test designating one as a "manufacturer" if one produces goods supplied in a box, container, package, wrapping, encasement, or housing of any nature that covers a product, or alters, repairs, or improves the product in any way. However, mere retail sale or supervision over production does not convert one from "middleman" to "manufacturer." In the trade context, mere importing and then retail (and activities associated with mere retail, such as minimal employment of warehouse and storage facilities, handling, delivery, development of customer lists of retailers, and local middlemen) would not qualify as activities that may be included in the calculation of the local content of a product. 
transformation" test (expanded as proposed) would be triggered. The company importing the product would owe tariffs under the applicable origin rules, unless the company has domesticated the product, thus transforming the product into one of domestic-origin, not an import; or the company's domestic participation is greater than what it would otherwise owe in tariffs and other protective measures.

One may object that the proposal is costly for companies to administer. Rules of origin compliance requirements, whether currently applied or as proposed in this Article, are indeed complex and costly to administer, which is one additional reason, among the other reasons discussed, ${ }^{309}$ why a true free trading regime would no longer retain them. This is especially true if an importer seeks the duty-free rate for products satisfying the particularly strict NAFTA rules of origin (or other strict preferential rules of origin) because the regulatory cost and inconvenience of meeting the requirements for customs verification purposes may outweigh the benefit. ${ }^{310}$ The transaction costs, however, could be balanced out by the incentives created by the proposal for participation offset, as described above.

\section{CONCLUSION}

I have argued that the United States and other countries in the world trading system should rethink two fundamental issues: "nationality" and "national origin." Trade laws are replete with provisions that make reference to domestic companies and domestic products. But dynamic changes caused by the international movement of capital and the globalization of production pose new challenges for the trading system. In a world in which U.S.-origin companies have significant operations offshore and foreignorigin companies have substantial operational presences in the United States, which standards should the United States or any other country use to determine what constitutes a domestic company? And if products are essentially global composites, with research and development, manufacturing, assembly and processing, and marketing each conducted in a different country, what is their country of origin? Under those circumstances, what is a domestic product?

The United States and other countries have responded to these developments in a disappointingly piecemeal manner, without a thorough examination of the changes that have blurred the distinction between the "national" and the "foreign" and without a reevaluation of the impact these changes have on international trade law and policy. Thus, depending on the political interests at issue at the time, a Honda is a North American product

309. See supra notes 262-65, 267-68.

310. See Gantz, supra note 172, at 395-97; Silveira, supra note 172, at 418,449 (“[C]ompliance with the rules in many cases forces eompanies to set up expensive internal procedures that add significantly to the cost of sales. Many would rather pay the tariff."). 
sometimes and a Japanese product another time. And more often than not, the nationality of a corporation continues to be determined in a reflexive manner, that is, by reference to antiquated tests more appropriate for a national, not postnational economic system. Yet, why should the place of incorporation continue to be a determinative factor in nationality determinations when companies are global in their orientation and conduct? And why should the nationality of controlling persons matter when their fiduciary duty obligates thein to make corporate decisions to maximize shareholder interest, not to further the general national interest?

Although "nationality" and "origin" are inextricably woven into trade laws and policy and thus are highly relevant to the globalization debate, neither nationalists nor internationalists have engaged in an examination of these issues. Instead, both accept the assumptions behind the terms "domestic" company, "domestic" products or "foreign" products, however inaccurate or misleading such terms have becoine. The nationalist project aims to derail international economic liberalization and reassert the rightful place of the national in the world trading system through the reinforcement of national borders and national economies against foreign companies and foreign products. The state is defended as the site for political governance, national cultures, and national sovereignty. The moorings of national community and the politics of identity are preferred over the abstractions of economic internationalisin and universalism.

By contrast, the internationalist project, perhaps because it is suspicious of nationalist passions and ambitions, is favorably inclined towards international liberalization, convergence, and interdependence. Within this economically integrated system, conflicts among nations are to be administered through a regime of rational and universal rules whereby the interests of the national and the international generally, and of domestic industry and foreign industry, domestic products and foreign products more particularly, are to be balanced and managed. Domestic industry should not be protected against imports as a general matter, except in cases of undue import surges or in cases of dumping or other unfair acts. Like the nationalist, however, the internationalist fails to grasp fully the extent to which distinctions between the national and the foreign have blurred.

Thus, despite their claiins of difference, both, curiously enough, share a few common assumptions. First, both continue to speak the same language and accept the same assumptions behind the current distinctions between "foreign" and "domestic" in trade laws, except that the nationalist seeks to protect that which is domestic-domestic companies and domestic products-from that which is foreign, and the internationalist seeks to accommodate and reconcile one with the other. And second, both continue to have their own blind spots: the nationalist to the global reality, and the internationalist to the populist appeal of matters grounded in the traditional 
framework of nationality. Human beings continue to respond to the pull of the community and the plight of those within their home territory. A French person might be a cosmopolitan citizen of the world, a European in the European Union, but she will also remain French. The internationalist somehow seems oblivious to those realities.

The proposal I advocate in this Article is one that aims to reconcile the appeal of loyalty to the national and the particular on the one hand with the current global logic of economic integration and liberalization on the other. I propose that these two interests be accommodated within the trading system itself, by re-evaluating the two basic premises of trade laws and adopting a new understanding of these premises. We thus return to the two original and pivotal questions posed at the outset: What is a domestic company and what is a domestic product? The test for corporate nationality, I argue, should be grounded in the company's substantial socioeconomic participation in a state's economy. Multinational or transnational companies maximizing their economic objectives in the global economy may be "anchored" in a state, not by the artifice of where they are incorporated or where management and shareholder control lies, but by their degree of commitment to that state's territorial boundaries. While the new test responds to the economic interests of the national, it does so without the threat of reinforcing national fortresses to keep out the international. Indeed, it does the opposite, by using the reality of corporate transnationalism to embrace the international within the national fold (through the added benefits and incentives of a participation offset right). In other words, corporate nationality, as revised, serves as the conduit through which to reassert the nationalist commitment to the relevance of place and at the same time reaffirm international aspirations and the global orientation of economic activities. Equally significant, this proposed test, I argue, is simply a more accurate refiection of developments that have occurred as a matter of fact.

One may worry, as an internationalist, however, that the proposed domestic participation test would cause multinational companies to vie for "nationality" status in rich countries with rich markets and iguore poor countries with poor markets. Given the trend towards regionalism and following in the examples of the European Union and NAFTA, developing countries have been exploring the possibility of forming their own regional free trade agreements. Initiatives towards such arrangements "can promote further liberalization and may assist least-developed, developing and transition economies in integrating into the international trading system." 311

311. Singapore Ministerial Declaration, WT/Min(96)/DEC, No. 96-5316 (Dec. 9-13, 1996), at http://www.docsonline.wto.org. There has been an increase in trade blocs, such as the Southern Cone Common Market ("MERCOSUR") and the Association of Southeast Asian Nations Free Trade Area ("AFTA"). An examination of regional trade agreements is beyond the scope of this Article. For a 
The establishment of a robust regional economy would also provide the nicentives for companies to become domestic participants of member countries.

In stark contrast to niternationalists, nationalists, particularly from the developed world, have bemoaned the shifting of corporate capital from the national borders of rich countries into those of the poorer countries. Globalization has produced both an international and national distributional fault line, among countries and groups within countries. Aganı, revising a basic premise of trade laws, product origin, would address this political problem. Rules of origin, far from benig neutral or innocuous, are in fact quite political. How they are interpreted has a direct and profound impact on where factories will be located and where economic activities will be centered. As the Article shows, products that are globally sourced are in fact the products of no one country in particular. Country-of-origin designations thus merely perpetuate this chimera of nationality in a world of internationality. Currently, the various tests used to elevate certain activities as endowing origin and to exclude other activities as not benig relevant for origin determination are themselves a reflection of political choices. These tests merely "freeze" the broad global picture to provide a "snapshot" that captures but a brief "national" moment, whereby the qualifying activities undertaken within that national territory are then deemed originconferring activities.

An internationalist corrective to this state of confusion would favor the elimination of the concept of product origin altogether, on the grounds that it is but a virtual figment of the national imagination. This remedy, I admit, is appealing if one allows oneself to mdulge fully in one's internationalist fantasies. My proposal, however, works from the existing framework of the WTO where rules of origni are very much a political and economic fact. In that respect, the proposal seeks to alter the current political choices behind rules of origin by expanding the range of qualifying activities ni order to accomplish two objectives: first, to reflect the emergence of the postindustrial economy and second, to address the nationalist fault lines that need to be dealt with to ensure the continued political survival of the current trading system.

The internationalist may want to tame nationalism, subject it to international discipline, and even exclude it as being incompatible with economic liberalization. And the nationalist, in turn, nıay want to exalt nationalist identity and protect national coinpanies and products aganist the unboundedness of international capital movenients. Yet, the world tradnig system to which the majority of countries belong would be best served if 
internationalism could enlist nationalism as its ally and vice versa. In this Article, I select two areas that form a basic foundation of trade laws, and illustrate how revising them along the lines articulated could achieve this objective. 